\title{
Ladies of Empire: \\ Governors' Wives in New Zealand, 1887-1926
}

by Sarah Burgess

A thesis submitted to Victoria University of Wellington in fulfilment of the requirements for the degree of Master of Arts in History

Victoria University of Wellington 



\begin{abstract}
Across the years 1887 to 1926, at a time when the British Empire was at its height, nine governors and their wives took up vice-regal office in New Zealand. This study is concerned with the public enactment of the position of vice-regal wives' in New Zealand in these years. It explores what it meant for a woman to be a public figure with a prominent profile and at the same time a wife within a marriage during the late nineteenth and early twentieth centuries. In doing so, the thesis looks at three distinct aspects of vice-regal life, as played out in public: official vice-regal ceremony and social life; involvement in voluntary welfare and women's imperialist organisations; and the display of vice-regal life through governors' wives' appearance and the furnishing of Government House. Of key concern is the way in which these aspects of vice-regal life are conveyed to the public through newspapers, and so Judith Butler's theory of gender performativity is considered as a way to think about the position occupied by governors' wives.

As women married to men in public office, governors' wives occupied a particular position and space within the British Empire in the late nineteenth and early twentieth centuries. The position was defined and created through marriage and through the enactment of the duties of vice-regal office. Governors' wives were present at vice-regal ceremonies and social events as both witnesses and wives; they involved themselves with voluntary welfare and imperialist organisations with a particular focus on women as mothers and contributors to Empire; and through their dress and the decoration of Government House governors' wives presented a display of their suitability for holding vice-regal office. The enactment of these duties over the period from 1887 to 1926 was remarkably consistent. Alongside this a degree of change occurred in the recognition afforded to governors' wives in the fulfilment of vice-regal office.
\end{abstract}




\section{Table of Contents}

Abstract $\quad$ i

Table of Contents $\quad$ ii

Acknowledgments iii

List of Abbreviations $\quad$ iv

List of Tables $\quad$ iv

Introduction 1

Chapter One

Ceremony and Duty 17

Chapter Two

Voluntary Welfare and Women's Imperialist Organisations

Chapter Three

Dress, Decoration, and Government House

Conclusion

89

Bibliography 


\section{Acknowledgments}

This thesis has been both challenging and rewarding and would not have been possible without the generous input of certain people.

I first must thank my supervisor, Charlotte Macdonald, for her insightful comments, suggestions, time, and support throughout the research and writing process of the last 12 months. A special thanks also to Jim McAloon for his help and guidance in the early stages of research.

Both the staff and my fellow post-grads in the History department at Victoria University of Wellington have provided a wonderful and supportive community in which to undertake this endeavour. This thesis would be much the poorer without them both. Thank you.

To my parents, for their unwavering support, love, and understanding of my desire to keep studying I owe so much. I promise I won't do a PhD!

To Harry, thank you, quite simply, for everything.

And finally, I must acknowledge George and Eliza Grey whose unhappy marriage first inspired my interest in governors' wives. Without them, this thesis would not exist. 


\section{List of Abbreviations}

ADC

Aide-de-camp

ATL

Alexander Turnbull Library

EP

Evening Post

GFS

Girls' Friendly Society

$\mathrm{NZH}$

New Zealand Herald

ODT

Otago Daily Times

RNZPS

Royal New Zealand Plunket Society

\section{List of Tables}

Table 1. List of governors' wives in New Zealand, 1887-1926 


\section{Introduction}

Between 1887 and 1926, nine women travelled from Britain to New Zealand with their husbands, men who were to take up the post of vice-regal representative. As women married to the governors and, later, governors-general of New Zealand, they occupied a privileged and elite public position. They were at the head of local society, and their movements and actions while in New Zealand were followed with interest by the public. These women helped their husbands to fulfil the post of viceregal office by taking part in imperial and local affairs. During their years in New Zealand, they participated in vice-regal ceremonies, attended and hosted social events, and promoted worthy causes and engaged in various ways with local communities. Exploring how governors' wives enacted these vice-regal duties is at the heart of this thesis. It seeks to investigate the position occupied by this group of women as wives, but wives married to men in public positions. In particular, it considers what the enactment of these duties says about the position of governors' wives within the British Empire at a time when debates over women's political rights and public activity were a subject of public discussion.

Governors were the representatives of the British sovereign and of the British government in its colonial possessions. They were at the apex of political and social life and more often than not governors' wives accompanied them on their overseas posting to help them in fulfilling the various duties of vice-regal office. Although governors' wives had no official position within the vice-regal establishment, they were nonetheless expected to play an important part in viceregal life. As wives of the sovereign's representative, they had considerable status and influence, but their public position meant that there were constraints in how that influence could be applied. They had to live up to the expectations of vice-regal office. Indeed, in many ways a governor's wife was considered to be as much a representative of the monarch as the governor himself. Her husband's vice-regal authority carried over to her, and so she was as responsible as her husband in upholding the dignity and status of vice-regal office. 
Despite their importance to the work of the governor, governor's wives have no official label by which they are known. Part of the reason for this lies in the fact that the position was not, and still is not, an official one. It is the governor or governor-general who is appointed to the position, not the spouse. How to label them, then, is challenging. While there are many options ('consort' being one for example), the term most commonly used is 'governors' wives' or 'vice-regal wives'. Although problematic in that they render this group of women into possessions of their husbands, it is also appropriate in that it reflects how these women come into the position, that is, through their marriage. As such, the term 'governors' wives' or 'vice-regal wives' will be used throughout the course of this thesis. As for the men in the role, 'governors' will be used throughout this study to refer to both the governors and governors-general who filled the office in New Zealand between 1887 and 1926. Although the position was elevated to that of governor-general in 1917, it makes sense to use 'governors' across the thesis. ${ }^{1}$ This is not only to maintain consistency in terminology, but also because for thirty of the almost forty years covered by this thesis, the position was held by a governor.

Between 1887 and 1926, nine governors and their wives occupied Government House in New Zealand (see table 1). Almost all came from aristocratic backgrounds, and almost all had never served as vice-regal representatives before. Sir William Jervois and his wife Lucy - the first of the nine vice-regal representatives covered in this thesis - were the last of New Zealand's representatives to serve in more than one vice-regal post. ${ }^{2}$ The Jervoises were also the least aristocratic of the nine. Sir William, the son of General William Jervois, a war veteran and former Governor of Hong Kong, had worked his way up through the military before accepting the first of his three vice-regal posts, while Lucy Jervois was the daughter of a London builder from Devon. ${ }^{3}$ The majority of the vice-regal representatives during these years also stayed in New Zealand for the full duration of their term in office, with only the Onslows and Islingtons retiring from the position before their

\footnotetext{
${ }^{1}$ In 1917, New Zealand's governors were elevated to governors-general in recognition of the country's contribution to the war effort. Gavin McLean, The Governors: New Zealand's Governors and Governors-General (Dunedin: Otago University Press, 2006), p.176.

${ }^{2}$ Sir William Jervois was governor of both the Straits Settlement and South Australia prior to his appointment as Governor of New Zealand in 1883. McLean, p.117.

3 John S. Kinross, 'Jervois, Sir William Francis Drummond (1821-1897)', Oxford Dictionary of National Biography, updated May 2009; doi:10.1093/ref:odnb/14800; accessed 7 November 2014.
} 
Table 1. List of governors' wives in New Zealand, 1887-1926

\begin{tabular}{|c|c|c|c|c|c|c|c|}
\hline $\begin{array}{c}\text { Governor's } \\
\text { Wife }\end{array}$ & Born 4 & Died & Governor & $\begin{array}{c}\text { Date of } \\
\text { marriage }\end{array}$ & Children & $\begin{array}{c}\text { Term in } \\
\text { Office }^{5}\end{array}$ & $\begin{array}{c}\text { Age } \\
\text { when } \\
\text { arrived } \\
\text { in New } \\
\text { Zealand } 6\end{array}$ \\
\hline $\begin{array}{l}\text { Lady Lucy } \\
\text { Jervois }\end{array}$ & [1830?] & $\begin{array}{c}18 \\
\text { March } \\
1895\end{array}$ & $\begin{array}{c}\text { Sir } \\
\text { William } \\
\text { Jervois }\end{array}$ & $\begin{array}{c}19 \text { March } \\
1850\end{array}$ & $\begin{array}{c}\text { Two sons, } \\
\text { three } \\
\text { daughters }\end{array}$ & $\begin{array}{c}20 \text { January } \\
1883-22 \\
\text { March } \\
1889\end{array}$ & [53?] \\
\hline $\begin{array}{l}\text { Florence, } \\
\text { Countess of } \\
\text { Onslow }\end{array}$ & 1851 & $\begin{array}{l}8 \text { August } \\
1934\end{array}$ & $\begin{array}{l}\text { Earl of } \\
\text { Onslow }\end{array}$ & $\begin{array}{c}3 \\
\text { February } \\
1875\end{array}$ & $\begin{array}{c}\text { Two sons, } \\
\text { two } \\
\text { daughters }\end{array}$ & $\begin{array}{c}\text { 2 May } \\
1889-24 \\
\text { February } \\
1892\end{array}$ & 37 \\
\hline $\begin{array}{l}\text { Dorothea, } \\
\text { Countess of } \\
\text { Glasgow }\end{array}$ & 1851 & $\begin{array}{c}23 \\
\text { January } \\
1923\end{array}$ & $\begin{array}{c}\text { Earl of } \\
\text { Glasgow }\end{array}$ & $\begin{array}{c}23 \text { July } \\
1873\end{array}$ & $\begin{array}{c}\text { Five sons, } \\
\text { three } \\
\text { daughters }\end{array}$ & $\begin{array}{c}7 \text { June } \\
1892-6 \\
\text { February } \\
1897\end{array}$ & 42 \\
\hline $\begin{array}{c}\text { Constance, } \\
\text { Countess of } \\
\text { Ranfurly }\end{array}$ & 1857 & $\begin{array}{c}25 \text { July } \\
1932\end{array}$ & $\begin{array}{c}\text { Earl of } \\
\text { Ranfurly }\end{array}$ & $\begin{array}{c}10 \\
\text { February } \\
1880\end{array}$ & $\begin{array}{c}\text { One son, } \\
\text { three } \\
\text { daughters }\end{array}$ & $\begin{array}{l}10 \text { August } \\
1897-19 \\
\text { June } 1904\end{array}$ & 40 \\
\hline $\begin{array}{l}\text { Victoria, } \\
\text { Lady } \\
\text { Plunket }\end{array}$ & $\begin{array}{c}17 \text { May } \\
1873\end{array}$ & $\begin{array}{c}\text { February } \\
1968\end{array}$ & $\begin{array}{c}\text { Baron } \\
\text { Plunket }\end{array}$ & $\begin{array}{l}4 \text { June } \\
1894\end{array}$ & $\begin{array}{c}\text { Three } \\
\text { sons, five } \\
\text { daughters }\end{array}$ & $\begin{array}{c}20 \text { June } \\
1904-8 \\
\text { June } 1910\end{array}$ & 30 \\
\hline $\begin{array}{l}\text { Ann, Lady } \\
\text { Islington }\end{array}$ & [1870?] & $\begin{array}{l}7 \text { August } \\
1958\end{array}$ & $\begin{array}{l}\text { Baron } \\
\text { Islington }\end{array}$ & $\begin{array}{c}30 \\
\text { September } \\
1896\end{array}$ & $\begin{array}{c}\text { One } \\
\text { daughter }\end{array}$ & $\begin{array}{c}20 \text { June } \\
1910-2 \\
\text { December } \\
1912\end{array}$ & [40?] \\
\hline $\begin{array}{l}\text { Annette, } \\
\text { Countess of } \\
\text { Liverpool }\end{array}$ & 1875 & $\begin{array}{l}\text { May } \\
1948\end{array}$ & $\begin{array}{c}\text { Earl of } \\
\text { Liverpool }\end{array}$ & $\begin{array}{c}27 \text { July } \\
1897\end{array}$ & $\begin{array}{c}\text { No } \\
\text { children }\end{array}$ & $\begin{array}{c}19 \\
\text { December } \\
1912-7 \\
\text { July } 1920 \\
\end{array}$ & 37 \\
\hline $\begin{array}{l}\text { Florence, } \\
\text { Lady } \\
\text { Jellicoe }\end{array}$ & [1880?] & $\begin{array}{l}\text { May } \\
1964\end{array}$ & $\begin{array}{l}\text { Viscount } \\
\text { Jellicoe of } \\
\text { Scapa }\end{array}$ & $\begin{array}{l}1 \text { July } \\
1902\end{array}$ & $\begin{array}{l}\text { One son, } \\
\text { five } \\
\text { daughters }\end{array}$ & $\begin{array}{c}27 \\
\text { September } \\
1920-26 \\
\text { November } \\
1924\end{array}$ & [40?] \\
\hline $\begin{array}{l}\text { Lady Alice } \\
\text { Fergusson }\end{array}$ & $\begin{array}{c}18 \\
\text { December } \\
1877\end{array}$ & $\begin{array}{c}1 \\
\text { January } \\
1958\end{array}$ & $\begin{array}{c}\text { Sir } \\
\text { Charles } \\
\text { Fergusson }\end{array}$ & $\begin{array}{c}18 \text { July } \\
1901\end{array}$ & $\begin{array}{c}\text { Four } \\
\text { sons, one } \\
\text { daughter }\end{array}$ & $\begin{array}{c}20 \\
\text { December } \\
1924-8 \\
\text { February } \\
1930\end{array}$ & 47 \\
\hline
\end{tabular}

${ }^{4}$ Where the wife's date of birth was unknown, a best guess was made based on her date of marriage, death date, and the age of her husband.

5 When there were periods of time between governors' terms in office, the position was filled by the chief justice who undertook all the official duties required of a vice-regal representative. McLean, p.51.

${ }^{6}$ As with the wife's date of birth, her age when she arrived in New Zealand was a best guess, based on the same criteria as for date of birth. 
term was due to end. ${ }^{7}$ Along with Jervois, several others also had previous experiences of vice-regal life. Victoria, Lady Plunket, wife of Governor Plunket, was born in Ottawa during her father's term as Governor-General of Canada in 1874, while the Fergussons were both children of former governors of New Zealand. ${ }^{8}$

When New Zealand became a possession of the British Empire in 1840, a governor was appointed to represent the British monarchy and government. In addition to this representative role, the first decade of the colony saw governors rule personally, assisted by an appointed Executive Council and Legislative Council. ${ }^{9}$ However it was not long before settlers began to agitate for a more representative form of government. As such, the New Zealand Constitution Act 1852 was passed, granting the colony representative government from 1853 onwards. This established a General Assembly (made up of the governor, a nominated Legislative Council, and an elected House of Representatives) empowered with the authority to make laws for New Zealand, although it remained subordinate to the governor. ${ }^{10}$ The governor had authority over the running of Parliament, being empowered with calling or dismissing the House and determining its time and place of meeting, along with considerable power over the passing of legislation. ${ }^{11}$ It was not until 1856 that responsible government was granted, an arrangement whereby the governor agreed to accept the advice of responsible ministers on domestic matters but retained authority over imperial matters and control of Māori policy. ${ }^{12}$ On these last two matters the governor agreed to refer ministers' views to the secretary of state if deemed necessary. ${ }^{13}$

Although these constitutional changes did alter the position of the governor, vice-regal office nevertheless remained the pinnacle of social and political life in

\footnotetext{
${ }^{7}$ Lord Onslow resigned in October 1891, citing an urgent need to attend to matters relating to his property in England. Lord Islington resigned his post in mid-1912 to take up a position as chair of a major commission on the Indian civil service. McLean, pp.140, 172.

8 Melanie Oppenheimer, "'Hidden under many bushels" Lady Victoria Plunket and the New Zealand Society for the Health of Women and Children', New Zealand Journal of History, Vol. 39, no. 1, 2005, p.26; McLean, pp.83, 206.

${ }_{9}^{9}$ McLean, p.9; W. David McIntyre, Dominion of New Zealand: Statesmen and Status 1907-1945

(Wellington: New Zealand Institute of International Affairs, 2007), p.28.

10 McLean, p.46.

${ }^{11}$ John E. Martin, The House: New Zealand's House of Representatives 1854-2004 (Palmerston North: Dunmore Press, 2004), p.11.

12 McLean, pp.11, 57; McIntyre, Dominion of New Zealand, pp.28-29.

13 McLean, p.57.
} 
New Zealand. Crucially, the incumbent continued to be a vital component of constitutional affairs and on occasion interfered in appointments to the Legislative Council. ${ }^{14}$ This situation would prove to be problematic and provoke conflict throughout the mid- to late-nineteenth century, as governors, politicians and the colonial office clashed with each other over the division of power. ${ }^{15}$ The mid to late Victorian era also saw the governor's role in ceremonial affairs become more elaborate and the type of man appointed by the British government to the vice-regal job reflected this change. Whereas in the early years of the colony governors had been military men or colonial administrators making a career for themselves in the Empire, from the 1880s onwards governors were increasingly likely to be members of the British aristocracy. ${ }^{16}$ At the same time, New Zealand's governors also ceased to take up further vice-regal appointments once their term in the colony came to an end. No longer did they engage in an imperial circuit, moving slowly up the ranks of governorships. Instead, they served once and once only, returning to Britain at the culmination of their term in office. ${ }^{17}$

This state of affairs, in which British aristocrats accepted the gubernatorial post and served one term before returning to England, continued well into the twentieth century. Little changed in the way the position was carried out - not even the granting of Dominion status in 1907 or the elevation from governor to governorgeneral in 1917 affected much change - until the 1930s and 1940s when New Zealand politicians began to enact the provisions of the Balfour Declaration. Moreover, governors continued to be British-born, and were always married men. In 1967 Sir Arthur Porritt became the first New Zealand-born man to become governor, and it was not until 1990 that a woman, Dame Catherine Tizard (also New Zealand's first governor not married at the time of appointment) was appointed to the office. 18

\footnotetext{
14 Ibid, pp.139-142.

15 Ibid, p.11.

16 McLean, p.117; Zoë Laidlaw, Colonial Connections, 1815-45: Patronage, the Information Revolution and Colonial Government (Manchester and New York: Manchester University Press, 2005), p.62.

17 McLean, pp.13, 117.

18 Porritt, although born in New Zealand, had lived in Britain most of his adult life and considered himself both a New Zealander and a "complete Pommy". The first governor to be both born and resident in New Zealand was Sir (Edward) Denis Blundell in 1972. McLean, pp.277, 279, 291, 324326.
} 
The study of governors' wives is located within the field of gender and empire, a field that has seen growth as an area of historical enquiry over the last twenty to thirty years. Feminist and post-colonial perspectives have increasingly been brought to bear on the study of the British Empire, probing and asking new questions, and in the process necessitating a rethink of how to approach the history of empire. This study seeks to contribute to that field. It is a field that is diverse and engaging, and which challenges traditional understandings of imperial history by linking family and intimate histories with the history of governance and administration. As Angela Woollacott noted in her comprehensive work on the British Empire, gender as an analytical category, "compels us to examine changing cultural and ideological definitions of masculinities and femininities, and at once allows us to explore such definition as sites of cultural encounter, and sites of the political contests that have always been integral to colonialism." ${ }^{19}$ Likewise, Philippa Levine, in her introductory chapter to Gender and Empire (a so-called 'companion volume' to the Oxford history of the British Empire) offered a compelling argument for the importance of applying gender as an analytical category to studies of empire. She considered that "the very idea [of the British Empire] as well as the building of empires themselves cannot be understood without employing a gendered perspective." 20 She furthermore saw gender as creating an opportunity to ask questions that allowed one to think "not just descriptively about Empire (how, who, where) but about why it came about and what made the particular sets of relations that might be identified as characteristic of the British Empire possible."21 Applying gender to the study of the British Empire opens up the field to new avenues of enquiry, furthering our understanding of a system that was pervasive in its reach and the impact it had on peoples around the world.

Crucial to the study of gender and empire is the understanding that gender is not a category of analysis separate to those of race or class, each of which are also intertwined in the story of the British Empire. Rather it is inextricably linked with

\footnotetext{
${ }^{19}$ Angela Woollacott, Gender and Empire (New York: Palgrave Macmillan, 2006), p.1.

${ }^{20}$ Philippa Levine, 'Introduction: Why Gender and Empire?' in Philippa Levine (ed.), Gender and Empire (Oxford: Oxford University Press, 2004), p.1.

${ }^{21}$ Ibid, pp.5-6.
} 
them. As Laura Lee Downs in Writing Gender History explained, "gender does not operate independently of race and class, creating women out of a single mould. Rather, gender relations and notions of ideal masculinity and femininity are partly constitutive of both racial and class hierarchies." 22 Gender is present and pervasive in these interactions, affecting women and men, colonised and coloniser, in different manners. As such, it is important not to assume a commonality of experience of empire across different gender, race, and class categories.

The position held by a governor's wife was one where these many strands came together. Working (albeit in an unofficial capacity) as a representative of the monarch alongside her husband, a governor's wife was intimately involved with the imperial project, although in a manner distinct to that of her husband. Her gender affected her experience of the vice-regal appointment and her experience of the colony. Likewise, her status at the apex of society positioned her above other women and men in the colony, while her whiteness (as a British woman) again set her apart from both indigenous peoples and a predominantly European settler population in the settler colonies. The governor's wife thus provides an excellent opportunity to explore the intersection between gender, class, and race within the British Empire.

In 1990, Jane Haggis cautioned against a growing tendency to write the history of white women in the empire in an uncritical, woman-centric way. ${ }^{23}$ Such histories, which sought to return women to the story of empire, risked alienating the voices of others - notably indigenous men and women - in their analyses. In seeking to restore western women's voices to the history of empire, such work silenced other aspects of the imperial project, notably race and class and the myriad ways in which gender interacts with both. Clare Midgley, in her introduction to the edited collection Gender and imperialism, noted how these works positioned white women either as victims of the patriarchy or feminist heroines, and at the same time "[ignored] their racial privileges in colonial society."24 Midgley did also note, however, that more recent works of the late 1990s had begun to take a more critical

\footnotetext{
22 Laura Lee Downs, Writing Gender History (New York: Hodder Arnold, 2004), p.67.

23 Jane Haggis, 'Gendering Colonialism or Colonising Gender? Recent Women's Studies Approaches to White Women and the History of British Colonialism', Women's Studies International Forum, Vol. 13, nos. 1-2, 1990, pp.105-115.

24 Clare Midgley, 'Introduction: Gender and imperialism: mapping the connections', in Clare Midgley (ed.) Gender and imperialism (Manchester: Manchester University Press, 1998), p.7.
} 
view of white women's involvement in imperialism, exploring the extent to which they were 'complicit' or 'resistant' or perhaps fell somewhere in between. ${ }^{25}$ This more critical approach has continued to this day, with historians investigating numerous subjects within the field of gender and empire. Within this sphere are many works on women married to colonial administrators, among them the wives of governors of both the white settler and non-white colonies of the British Empire.

Vice-regal wives have received increasing attention on the part of historians over the last fifteen years. The focus so far on vice-regal wives has mostly been at the individual level but it has also been fairly widespread in traversing the British Empire, with many studies directing their research at particular governors' wives in the white settler colonies, notably Canada and the Australian colonies. Notable works in these areas are those by Penny Russell, Alison Alexander, Val McLeish and Melanie Oppenheimer. ${ }^{26}$ Other works, such as those by Nicola J. Thomas, or Helen Callaway and Dorothy 0. Helly, have looked at wives in non-white colonies, exposing the differences and difficulties in being a governor's wife in these parts of the Empire as opposed to the settler colonies. ${ }^{27}$ Elizabeth Taylor's work on Lord and Lady Northcote, who served in both Australia and India, meanwhile straddles both types of colony. ${ }^{28}$ In addition, earlier studies of governors' wives have been based in

\footnotetext{
25 Ibid.

${ }^{26}$ See, in particular, Penny Russell, 'A Woman of the Future? Feminism and Conservatism in Colonial New South Wales', Women's History Review, Vol. 13, no. 1, 2004, pp.69-90; Penny Russell, 'Wife Stories: Narrating Marriage and Self in the Life of Jane Franklin', Victorian Studies, Vol. 48, no. 1, Autumn 2005, pp.35-57; Alison Alexander, The Ambitions of Jane Franklin (Sydney: Allen \& Unwin, 2013); Alison Alexander, “'Interfering Woman”: Jane Franklin and Van Diemen's Land Politics', Papers and Proceedings: Tasmanian Historical Research Association, Vol. 59, no. 2, August 2012, pp.77-94; Val McLeish, 'Sunshine and Sorrows: Canada, Ireland and Lady Aberdeen', in David Lambert and Alan Lester (eds.), Colonial Lives Across the British Empire: Imperial Careering in the Long Nineteenth Century (New York: Cambridge University Press, 2006), pp.257-284; Melanie Oppenheimer, 'The "imperial" girl: Lady Helen Munro Ferguson, the imperial woman and her imperial childhood', Journal of Australian Studies, Vol. 34, no. 4, December 2010, pp.513-525.

27 See Nicola J. Thomas, 'Mary Curzon: “American Queen of India”', in David Lambert and Alan Lester (eds.), Colonial Lives Across the British Empire: Imperial Careering in the Long Nineteenth Century (New York: Cambridge University Press, 2006), pp.285-308; Helen Callaway and Dorothy 0. Helly, 'Crusader for Empire: Flora Shaw/Lady Lugard', in Nupur Chaudhuri and Margaret Strobel (eds.), Western Women and Imperialism: Complicity and Resistance (Bloomington and Indianapolis: Indiana University Press, 1992), pp.79-97. 28 Elizabeth Taylor, The Old World and the New: The Marriage and Colonial Adventures of Lord and Lady Northcote (Newcastle upon Tyne: Cambridge Scholars Publishing, 2013).
} 
similar time periods, often positioned within the late nineteenth and early twentieth centuries, although there is the occasional outlier. ${ }^{29}$

Within the New Zealand context, there is little in the way of research on viceregal wives. Gavin McLean undertook a study of all New Zealand's governors from 1840 to 2006 , focussing in large part on the key events during each man's term in office, and, although he did take some time to mention the women (and eventually men) who accompanied their spouses in taking up office, there was little in the way of analysis of the spouse's position. The book remained largely descriptive in this area. ${ }^{30}$ Even Lady Eliza Grey, who was married to one of the more notable of the country's governors and who had a famously unhappy marriage, features little in her own right in the New Zealand scholarship. ${ }^{31}$ Lady Victoria Plunket is the New Zealand wife that is most commonly dealt with due to her involvement in the creation of the Royal New Zealand Plunket Society.32 Lady Beverley Reeves meanwhile, wife of the governor-general between 1985 and 1990, took it upon herself to write about her experience as a vice-regal wife. ${ }^{33}$

What the existing scholarship on governors' wives has demonstrated is the many varied experiences of the position across space and time. For some governors' wives, the position offered an opportunity to pursue personal ambitions and interests. Val McLeish's article on Lady Aberdeen, a governor's wife in Canada in the 1890s and Ireland in the first decades of the twentieth century, is illustrative of this aspect of vice-regal life. McLeish demonstrated how Lady Aberdeen utilised her position as a vice-regal wife to her advantage in advancing her own ambitions and

\footnotetext{
${ }^{29}$ Jane Franklin, a vice-regal wife in Van Diemen's Land from 1837 to 1843, is one wife commonly studied outside of those from the late nineteenth and early twentieth centuries.

${ }^{30}$ McLean, The Governors.

${ }^{31}$ Lady Grey features in small ways in works on nineteenth-century women in New Zealand and also as the subject of a self-published biography. See, Frances Porter and Charlotte Macdonald (eds.), 'My Hand Will Write What My Heart Dictates'. The unsettled lives of women in nineteenth-century New Zealand as revealed to sisters, family and friends (Auckland: Bridget Williams Books and Auckland University Press, 1996); and Harry Bioletti, Whatever Happened to Lady Grey? A Look into the Private Lives of Lady Eliza Lucy Grey and Sir George Grey (Auckland: Harry Bioletti, 2001).

32 In addition to Oppenheimer's article, Lady Plunket has also featured in works connected with the Plunket Society. Oppenheimer, "Hidden under many bushels"'; Lloyd Chapman, In a Strange Garden: The Life and Times of Truby King (Auckland: Penguin Books, 2003); Linda Bryder, $A$ Voice for Mothers: The Plunket Society and Infant Welfare, 1907-2000 (Auckland: Auckland University Press, 2003). ${ }^{33}$ Beverley Reeves, Playing the Part: My Life as Wife of the Governor-General (Auckland: Reed Books, 2007). Lady Reeves also wrote a thesis on the subject of being married to a man in office as part of a Master of Arts in Women's Studies: Beverley Reeves, 'The effect on a woman's life of being married to a man of high status', MA thesis, Victoria University of Wellington, 2000.
} 
imperial causes such as the Victorian Order of Nurses. ${ }^{34}$ Likewise Penny Russell and Alison Alexander's studies of Lady Jane Franklin, governor's wife in Van Diemen's Land from 1837 to 1843 , have shown her to be equally ambitious for both herself and her husband, and to have made the most of her vice-regal position in the pursuit of these ambitions. ${ }^{35}$ Unlike Lady Aberdeen, however, who steered clear of colonial politics, Lady Franklin's ambitions did cause some controversy when she was thought to have overstepped her bounds and interfered in the politics of Van Diemen's Land. ${ }^{36}$ What McLeish, Russell, and Alexander's studies demonstrate is the opportunity to pursue personal ambitions which vice-regal office provided to governors' wives and also the limits on where and how these ambitions could be realised.

In her study of Lady Margaret Jersey in New South Wales between 1891 and 1892, Russell further illustrated the tension faced by governors' wives through their position of power and their status as imperial ladies. Russell argued that at a time when the idea of the 'new woman' was prominent and women's political participation was a topic of debate, Lady Jersey's elevated imperial status in the colony and the power that afforded her, in combination with her own aristocratic confidence, led her to become a figure of female possibility and a focal point for debates between conservative elements of New South Wales society and local feminist groups. ${ }^{37}$ Russell's argument exposed one of the tensions faced by governors' wives as women of public influence and authority at a time when the majority of women had little in the way of political power.

The importance of marriage to the position of governors' wives is another feature of the existing scholarship. While not connected specifically to vice-regal wives, Mary A. Procida's book on the wives of British colonial administrators from the 1880 s to the mid-twentieth century nonetheless noted the importance of marriage to imperial work and the many ways in which wives helped their husbands

\footnotetext{
34 McLeish, pp.257-284.

35 Russell, 'Wife Stories', pp.35-57; Alexander, The Ambitions of Jane Franklin; Alexander, '“Interfering Woman"', pp.77-94.

36 Alexander, '“Interfering Woman"', pp.81-84, 91-94.

37 Russell, 'A Woman of the Future?', pp.69-90.
} 
in carrying out their duties and furthering the aims of the Empire. ${ }^{38}$ On marriage and vice-regal wives, Russell, in showing the opportunities that vice-regal office gave Lady Franklin, also illustrated how marriage did the same. According to Russell, being married, "widened the boundaries of her mobility and public engagement", giving her space to travel and experience different cultures and peoples. ${ }^{39}$ Governors' wives were in their position by virtue of their marriage and it was this wifely status which unlocked doors previously closed to them.

Existing scholarship has also established a link between governors' wives and what has come to be understood as 'female imperialism', the gendered work of women to promote the imperial mission around the Empire. Amanda Andrews looked at three governors' wives in Canada, India, Ireland and Australia between 1884 and 1914, arguing that during this period a new kind of vice-regal woman emerged, one who was less the ornamental figure of the past and more a woman actively engaged in promoting the Empire. ${ }^{40}$ McLeish's study of Lady Aberdeen similarly noted how vice-regal wives' increasing involvement in voluntary welfare and women's organisations during this time were demonstrative of a 'new' viceregal woman. ${ }^{41}$ Key to this understanding of vice-regal wives from the $1880 \mathrm{~s}$ onwards as 'new' was the idea of female imperialism, whereby elite women sought a greater role for themselves within the British Empire. ${ }^{42}$ Through the establishment of societies and organisations which endeavoured to carry out women's gendered imperial work (such as assisting women to emigrate, supporting missionary and church work in the colonies, and establishing strong links between the colonies and 'Home'), women embarked on a mission to contribute to the building of the Empire. As prominent women in the colonies with authority and influence, and holding an imperial position, governors' wives were well suited to the task.

What these existing studies have shown are the complexities and tensions of the vice-regal wife's position, particularly during the late nineteenth and early

\footnotetext{
${ }^{38}$ Mary A. Procida, Married to the empire: Gender, Politics and Imperialism in India, 1883-1947

(Manchester: Manchester University Press, 2002).

${ }^{39}$ Russell, 'Wife Stories', p.40.

${ }^{40}$ Amanda Andrews, 'The Great Ornamentals: New Vice-Regal Women and their Imperial Work 18841914', PhD thesis, University of Western Sydney, 2004.

${ }^{41}$ McLeish, p.257.

42 On the subject of female imperialism, see Julia Bush, Edwardian Ladies and Imperial Power (London: Leicester University Press, 2000) and Katie Pickles, Female Imperialism and National Identity: Imperial Order Daughters of the Empire (Manchester: Manchester University Press, 2002).
} 
twentieth centuries when women's political participation was under debate. They have also elaborated on the influence of marriage and imperialism on the way in which the vice-regal lady carried out her position. This study seeks to extend and build upon many of these previous themes and arguments but in a New Zealand context. In particular, it looks to focus on the public position of governors' wives, rather than focusing on each individual wife's experience. The question remains, however, as to how best to understand the public position of governors' wives and the way in which they carried out their imperial duties. On this matter, Judith Butler's theory of gender performativity offers a possible answer.

Butler's influential work Gender Trouble, first published in 1990, in which she challenged the way we think about gender, sex, sexuality and identity, has been hugely influential in a wide field of subjects. In particular, her theory of gender performativity opened up new ways of thinking about how gender (and other) identities are constructed. Butler's theorisations on gender stemmed from her engagement with feminist discourse and her criticisms of its assumption of heterosexual categories which, as she explained in her 1999 preface to the book, "restricted the meaning of gender to received notions of masculinity and femininity." 43 As part of Butler's deconstruction of gender, she built on Simone de Beauvoir's suggestion that, rather than being born a woman, one becomes a woman. However, she differed from de Beauvoir in that she did not assume the existence of a subject who takes on a gender. Rather, in Butler's theorisation, gender comes into being through a series of repeated actions which themselves constitute what they purport to be. Crucially for Butler, there is no subject which enacts these repeated actions. Instead, and contrary to what one might expect, the subject is the effect of, rather than the cause of, these actions. ${ }^{44}$ It is in this way that gender is performative.

That is not to say that performative actions equate to a performance. A performance presupposes the existence of a subject who knowingly carries out actions, an idea famously articulated by Erving Goffman in his influential The Presentation of Self in Everyday Life. Goffman described performance as, "all the activity of an individual which occurs during a period marked by his continuous

\footnotetext{
${ }^{43}$ Judith Butler, Gender Trouble: Feminism and the Subversion of Identity, (New York and London: Routledge, 2006), p.viii.

${ }^{44}$ Ibid, p.34.
} 
presence before a particular set of observers and which has some influence on the observers." ${ }^{45}$ For Goffman, the performer consciously carried out their actions, a concept which is substantially different to the idea of performativity articulated by Butler. This difference is an important one to take note of, especially when considering whether the actions of governors' wives can be considered performative.

The duties of a governor's wife were often referred to as being 'performed' in contemporary newspaper accounts, a description which brings to mind the idea that governors' wives were putting on a show of their vice-regal duties. ${ }^{46}$ Applying Butler's theorisation of gender performativity to the governors' wives' position provides an opportunity to examine how these duties were being 'performed'. Governors' wives occupied a strongly defined space. As women in the public eye and as women married to the representative of the monarch they embodied - and were expected to embody - a certain ideal of womanhood. Their actions as vice-regal spouses can potentially be understood to have reinforced this ideal, and possibly, to have created it. By carrying out their duties in a particular way, the wives performed their vice-regal identity. In examining vice-regal wives' position in this manner, that is, by considering the enactment of governors' wives' duties through the lens of performativity, a deeper understanding of how the position was formed and established is possible.

In 1887 Queen Victoria celebrated her golden jubilee, marking fifty years on the throne and the start point for discussion in this thesis. The jubilee was a celebration of both monarchy and empire and signified an increase in the ceremony and ritual of both institutions, as well as strongly linking together monarchy and empire in the public consciousness. As David Cannadine noted, prior to Queen Victoria becoming Empress of India in 1877 and before her two jubilee celebrations (those of 1887 and 1897), "no royal ceremonial occasion could plausibly have been called an imperial

\footnotetext{
${ }^{45}$ Erving Goffman, The Presentation of Self in Everyday Life (New York: Doubleday Anchor Books, 1959), p.22.

${ }^{46}$ Opening and closing ceremonies were often described in contemporary newspapers as being "performed" by governors' wives. See, for example: 'Wellington Exhibition', Otago Daily Times (ODT), 4 February 1897, p.2; 'Canterbury Jubilee Exhibtion', ODT, 25 August 1900, p.8; 'Plunket Society', Press, 13 November 1926, p.2; 'Daffodil Show', Evening Post (EP), 9 September 1926, p.11.
} 
event." 47 In the same year, the First Colonial Conference met in London, the first of several regular meetings between Britain and its self-governing colonies which provided an opportunity to discuss matters ranging from "Imperial defence and trade to the laying of the 'all red route' of transoceanic cables and the Imperial penny post." 481887 can thus be understood as a year which witnessed the flourishing of imperial fervour and a formal strengthening of ties between Britain and its colonies.

1926, the end point of discussion, marked a shift in the relationship between Britain and the dominions. At that year's Imperial Conference the Balfour Declaration was signed, acknowledging the equal status of Britain's Dominions with the United Kingdom as members of a Commonwealth of Nations. ${ }^{49}$ Although this aspect of the Declaration was not enacted by the United Kingdom until 1931 with the passing of the Statute of Westminster, and not adopted by New Zealand until 1947,50 the Declaration nevertheless signified the beginning of changes to New Zealand's formal constitutional relationship with the 'mother country'. Significantly, it also permitted a change in the position of governors-general, who would from that point on represent only the Crown in the Dominions, with High Commissioners taking on the role of representing the British government. ${ }^{51}$ Canada was the first of the Dominions to effect this change, appointing a High Commissioner in 1929; New Zealand followed some ten years later. ${ }^{52}$ Notwithstanding that New Zealand retained a governor-general as the representative of both the Crown and the British Government until 1939, this aspect of the Balfour Declaration remains significant in that it created the possibility for change and altered the meaning of the role of governors-general more generally.

\footnotetext{
47 David Cannadine, 'The Context, Performance and Meaning of Ritual: The British Monarchy and the "Invention of Tradition", c. 1820-1977', in Eric Hobsbawm and Terence Ranger (eds.), The Invention of Tradition (Cambridge: Cambridge University Press, 1995), p.124. ${ }^{48}$ E. H. H. Green, 'The Political Economy of Empire, 1880-1914', in Andrew Porter (ed.), The Oxford History of the British Empire Volume III: The Nineteenth Century (Oxford: Oxford University Press, 1999), p.347.

${ }^{49}$ McIntyre, Dominion of New Zealand, pp.117-128.

50 Ibid, p.131.

${ }^{51}$ Ibid, p.124; David Cannadine, The Decline and Fall of the British Aristocracy (New Haven: Yale University Press, 1990), p.600.

52 McIntyre, Dominion of New Zealand, p.124.
} 
The time period under discussion has been selected in part because of the significance of the years 1887 and 1926 as described above, but also because they cover a substantial period of time which featured a wide range of important events in New Zealand and imperial history. Not only do Queen Victoria's jubilees (golden and diamond) feature, but so does her death in 1901, and the reigns of two more Kings - Edward VII and George V after her. The Anglo-South African War and World War One are also covered by this time period, both significant wars in which New Zealand took part as members of the Empire. Closer to home, 1893 saw women in New Zealand win the vote, while in 1907 New Zealand was granted Dominion status, and 1916 witnessed the formation of the New Zealand Labour Party. These events provide a backdrop against which to examine the governor and his wife and the manner in which the enactment of the vice-regal position may or may not have changed over this time.

As this thesis is primarily concerned with the public enactment of a governor's wife's position and duties, it focuses on New Zealand newspapers as the main source of evidence for analysis. In order to manage the large amount of information available from this source, a selective strategy was undertaken. Four newspapers, the New Zealand Herald (Auckland), the Evening Post (Wellington), the Press (Christchurch) and the Otago Daily Times (Dunedin) were examined between the years 1887 and 1926. These four were selected so as to cover the four principal metropolitan centres of New Zealand at the time of the study. ${ }^{3}$ These newspapers covered not only local but also national events, and so a large scope of vice-regal activity can be found in their pages. Indeed, vice-regal activity was a staple of newspaper reports at this time and the sheer wealth of information available in their pages is overwhelming. The newspapers detailed important ceremonies and events in which the governor and his wife were involved, listed their itineraries for the day or week, and also provided social commentary on the actions and behaviour of the

\footnotetext{
${ }^{53}$ All four were searched using Papers Past (http://paperspast.natlib.govt.nz/cgi-bin/paperspast), an online collection of digitised New Zealand newspapers and periodicals covering the years 1839 to 1945. It is organised and maintained by Te Puna Mātauranga o Aotearoa, the National Library of New Zealand. Three of the four newspapers are digitally available throughout the years covered by the thesis (1887 to 1926). The Otago Daily Times, however, is only available on Papers Past between 1861 and 1920. As such, additional research of the Otago Daily Times was conducted to cover the years 1921 to 1926 using the copies available on microfilm at the National Library, Wellington.
} 
vice-regal couple. Newspapers described the vice-regal pair's public engagements and in doing so, made them accessible figures to the general New Zealand public.

Focussing on newspapers as the main source material is an unusual avenue to take in the study of elite individuals or groups. Commonly, such research makes use of personal papers. However, personal papers are less important to this study due in part to the focus of the thesis on the public side of vice-regal office, but also because women's private papers are not always readily available. In the case of the nine women who were governor's wives between 1887 and 1926, few left much of a personal record. Of those who did, the documents available within New Zealand were often patchy in their coverage and would not have provided sufficient evidence for the public angle taken by this research. In most cases, it was necessary to look through the governors' own personal papers to find the wives. Regardless, where personal papers were available, they were examined, and their contents do contribute and feature here.

The shape and structure of the thesis was determined in large part by the central features of vice-regal life and the question of how governors' wives participated in the public display of the office. Chapter one deals with vice-regal ceremonial and constitutional events, and the social aspect of vice-regal life. It seeks to locate governors' wives in these events, and in doing so considers how marriage influenced and shaped the way in which these events were carried out. Meanwhile, chapter two focuses on governors' wives' involvement in voluntary welfare and women's imperialist organisations. Focussing on a few select examples, notably the Plunket Society and the Lady Liverpool Fund, the chapter sets out to place vice-regal wives and their work in this area within a context of women's increasing role in public activity, at a time where women's political participation and rights were under consideration. The third chapter takes a step back from vice-regal activities themselves, and looks instead at the display of governors' wives through their dress, decoration choices, and Government House. In particular it looks at what the details of vice-regal dress and ornamentation signal about the position of governors' wives at this time. Throughout, the public nature of the position and the manner of its enactment are in focus. 


\section{Chapter One \\ Ceremony and Duty}

At a farewell banquet given to the Onslows before their departure from New Zealand in 1892, Charles Louisson, the former mayor of Christchurch, proposed a toast to the Countess of Onslow noting the extent to which she had enhanced her husband's success as governor of the colony. Lord Onslow, in replying to the toast, acknowledged that, "the wife of a Governor was no mean help in the discharge of his duties". ${ }^{54}$ Recognising the part played by their wife during vice-regal terms in New Zealand was a common occurrence when the time came for the governor to depart. Such an acknowledgment hinted at the importance of governors' wives' to carrying out the formal duties of vice-regal office. Although the governor was the person appointed to the office, his wife played an equally important part in the discharge of that office. Examining the nature of the part she played and what the wife's duties were alongside those of the governor is at the heart of this chapter. As such it seeks to locate the wife in the formal duties of the vice-regal position and in doing so explore how exactly governors' wives helped in the discharge of duties.

During their term in office, governors participated in both the political and social worlds of New Zealand. They were critical to political affairs and the leaders of social life. From the moment their ship docked in harbour or their train pulled into the station, they engaged in a performance of their official duties. Beginning with the landing ceremony in which the new vice-regal representatives were cheered by crowds of thousands as they disembarked from vessel or carriage before undertaking a procession through the city streets to Parliament for the oath-taking ceremony, governors became the focal point of New Zealand public life. Their movements were detailed and commented upon in newspapers and they lived in the public eye, partaking in social, ceremonial, and constitutional events as the occasion demanded.

There was an established routine and regularity to these events. At the start of each session of Parliament, the governor undertook the formal opening of

\footnotetext{
54 'Lord Onslow's Departure', ODT, 12 February 1892, p.2.
} 
Parliament, normally held in the New Zealand winter (although the date could vary if a general election had been called). ${ }^{55}$ Other important events on the vice-regal calendar included birthday celebrations for the reigning monarch, levees and 'at homes' during which members of New Zealand 'society' were invited to the viceregal residence to meet the governor and his wife, and Government House balls and garden parties. In addition to hosting events at Government House, the governor also attended various parties and balls, and travelled throughout the country visiting smaller towns. Newspapers reported these movements on a regular basis, noting where and when the governor would be ahead of time. ${ }^{56}$ Such reports allowed New Zealanders to know and to follow what the governor was doing as the monarch's representative.

In addition to the regular items on the vice-regal calendar, the years between 1887 and 1926 were host to various imperial occasions. Governors played a significant part in New Zealand's participation in such events. Queen Victoria's Golden and Diamond Jubilees were celebrated in 1887 and 1897 respectively, while 1901 saw her death mourned across the Empire. Two coronations, that of Edward VII in 1901 and George V in 1910 were also celebrated in New Zealand, with Government House hosting balls in honour of the occasions, while the 1901 Royal Tour presented a chance for New Zealand and the governor to offer their hospitality to the Duke and Duchess of York. In 1907 the colony became the Dominion of New Zealand, with then-Governor Lord Plunket leading celebrations. Meanwhile, the Anglo-South African War (1899-1902), World War One (1914-1918), the influenza epidemic (1918) and other crises all saw the governors take the lead in the public response to these emergencies. In these, and their more regular duties, the governors were accompanied by their wives.

Governors' wives were an important element in the success of their husbands' terms in office and carried out various duties in tandem with those of the governors. Yet the wives held no official position in the sense of having a defined role to undertake. All bar one of the ladies of this study were in the position for the

\footnotetext{
55 Martin, p.43.

56 For example, the Press on 7 February 1914 listed the governor's itinerary for the week ahead, noting what part of the country he would be in and what event he would attend on each day. See: 'The Governor and Lady Liverpool', Press, 7 February 1914, p.11.
} 
first and only time, and so they devised their role over time. The power and position held by the wives in New Zealand society was due to their marriage and the status afforded to them as women married to the monarch's representative. It was the governor who was appointed to the position by the Colonial Office, not the wife. Yet he was generally appointed as a married man and there was an expectation that not only would he take on the position, but so would his wife. She would accompany him and carry out the duties of vice-regal office alongside him. Governors and their wives would both be the monarch's representative, although the wives became such due to the marriage bond. This elevated status and association with royalty gave the governors' wives authority, responsibility, privilege and a degree of influence in the country. Examining how the wives carried out their vice-regal duties between 1887 and 1926 provides an opportunity to explore the wives' position in the vice-regal establishment.

Early in 1865 the New Zealand Parliament shifted from Auckland to Wellington, establishing Wellington as the capital city and the seat of political power. Initially, parliamentary proceedings took place in the Provincial Council building which, in addition to being in a deteriorating condition, soon proved to be too small to effectively accommodate government affairs. ${ }^{57}$ Gradual improvements and additions were made to the building so that by 1876 the site hosted a gothic-style set of buildings comprising both the Legislative Chamber and the House of Representatives, along with an enlarged parliamentary library. ${ }^{58}$ The new Government Buildings, which housed government departments, were also completed at this time and were located across the road from the parliamentary buildings. ${ }^{59}$ Further works on the parliamentary buildings and grounds continued throughout the 1890s. ${ }^{60}$ Following a fire on 11 December 1907 which consumed most of the wooden buildings save the library, Parliament moved into Government House for the 1908 session where it remained for the next ten years. ${ }^{61}$ Construction

\footnotetext{
57 Martin, p.43.

58 Ibid, pp.45-47.

59 Ibid, p.49.

60 Ibid, pp.128-130.

61 Ibid, pp.136-137, 155.
} 
of new parliamentary buildings did not begin until 1914.62 Due to uncertainty over completing the design and build, the buildings remained incomplete until the 1960s. ${ }^{63}$ Despite these uncertainties, Parliament resumed its business in the incomplete structure in $1918 .{ }^{64}$

The parliamentary buildings were the site of the State Opening of Parliament, one of the more important ceremonies in which the governor took part. It was the ceremony most visibly linked to his constitutional role, and resembled in form that which was followed in London. The opening ceremony was one where the New Zealand public could witness the governor carrying out one of his official duties, where he could be seen to 'govern'. It was an occasion of great ritual and tradition and one which followed a more or less set formula. Upon his arrival at Parliament, the governor entered the Legislative Council Chamber and awaited the arrival of the members of the House of Representatives. The ceremony took place in this chamber rather than the House of Representatives as, following British tradition, no monarch has set foot in the House of Commons since Charles I's attempt to arrest five Members of Parliament from the Commons in 1642.65 As the monarch's representative the governor faced the same restrictions. Upon the arrival of the members of the House of Representatives, the governor read the Speech from the Throne. This speech was written by the elected government of the day and outlined the government's plans for the coming parliamentary session. Upon the completion of the speech, the governor left Parliament. The entirety of the ceremony was carried out with great pageantry and ritual and was indicative of the importance of the governor to constitutional proceedings.

On 26 April 1887, Sir William Jervois opened the fourth session of the ninth Parliament of New Zealand, "with the customary formalities". ${ }^{66}$ As the Governor left Government House - then located next to the parliamentary buildings - the D Battery Artillery fired a salute from the Drillshed and an honour guard formed up outside the entrance to the Legislative Council Chamber. The Governor entered the

${ }^{62}$ Ibid, p.155.

63 Ibid, pp.247-251.

64 Ibid, p.155.

${ }^{65}$ Christopher Jones, The Great Palace: The Story of Parliament (London: British Broadcasting Corporation, 1983), pp.185-187; J. A. G. Griffith and Michael Ryle, Parliament: Functions, Practice and Procedures (London: Sweet \& Maxwell, 1989), pp.181-182.

66 'Opening of Parliament', EP, 26 April 1887, p.3. 
chamber at 2 o'clock, accompanied by his two aides-de-camp (ADCs), Captains Fortescue and Medley, his private secretary, Major Jervois, a few military officials, and various foreign consuls. The Governor's wife, Lady Jervois, and their daughter took seats in the main body of the chamber along with a number of other ladies. Upon the members of the House of Representatives arriving, Jervois read the Speech from the Throne, thus opening the new parliamentary session. ${ }^{67}$

The opening ceremony followed much the same sequence later the same year following the general election. At 2 o'clock on 12 October 1887, a salute was fired and the Governor arrived at the entrance of Parliament by carriage. Again, the D Battery of Artillery formed an honour guard while the Garrison Band played 'God Save the Queen' as the Governor entered the council chamber, followed by his ADCs, military men and foreign consuls. He took his seat upon the dais while Lady Jervois and their daughter took seats to the left of the dais. Lady Jervois was then presented with a bouquet of flowers. After giving the Speech from the Throne, another salute was fired, the band again played the national anthem, and the Governor and his party left, the first session of the tenth Parliament now being officially open. ${ }^{68}$

Again in 1889 events followed the same formula. A salute was fired, a guard of honour formed, and the Governor (the position now filled by the Earl of Onslow) entered followed by his ADCs, military men, and foreign consuls. Upon arriving, Lady Onslow and their daughter were escorted to a seat of honour by the Speaker of the Legislative Council, Sir William Fitzherbert, who presented the Countess with a bouquet of violets. His Excellency then walked up to the throne, bowing to the councillors present and read the speech. ${ }^{69}$ In all the newspaper articles which detail the opening ceremony between the 1880s and 1920s, the actions are virtually the same..$^{70}$ All that changes are the names of those present. The roles remain constant and in keeping with parliamentary ritual and tradition.

\footnotetext{
67 Ibid.

68 ODT, 13 October 1887, p.3, column 1.

69 'Opening of Parliament', ODT, 21 June 1889, p.2; 'Political Intelligence', ODT, 21 June 1889, p.2.

70 See for example: 'The Opening of Parliament', Press, 24 June 1892, p.5; 'Opening of Parliament', Press, 24 June 1899, p.8; 'Opening of Parliament', Press, 22 August 1906, p.7; 'Opening of Parliament', Press, 28 June 1912, p.8; 'War Session', EP, 9 May 1916, p.8; 'Parliament. The Opening Ceremony', Press, 29 June 1922, p.6; 'Parliament. Opening of Session', New Zealand Herald (NZH), 26 June 1925, p.11.
} 
This continuity in the ritual of opening Parliament signifies the stability and longevity of the British constitutional system. The procedure followed in New Zealand was the same as that followed in Britain with the governor taking the place of the monarch. The ceremony acted as a link between the mother country and her imperial possession, reinforcing the bond between the two. Giving the New Zealand ceremony more weight is the fact that, like Britain, New Zealand did not - and still does not - have a formal written constitution. The opening of Parliament by the governor was not only a time where he was visibly seen to carry out his function, but also, in some ways, the literal enactment of the constitution.

The wives of the governors and governors-general between 1887 and 1926 all attended the opening of Parliament and carried out much the same function during the ceremony. They all entered the chamber and were seated next to the throne from which the governor made the speech. On almost every occasion the wives were also given flowers by the Speaker of the House. They sat and listened while the governor gave the speech, and after the governor had performed this duty, they departed Parliament with their husband and any other members of the viceregal party. Beyond this, governors' wives took little part in the event. It would be easy to dismiss the wives' part in the opening ceremony as little more than ornamental based on this evidence. But there is much to be said about their presence, in particular as both a means of legitimising proceedings and also as a signifier of the governor's marital status, itself a legitimising function of vice-regal office.

Governors' wives played an active role in the proceedings of the opening of Parliament. Although the governors, positioned at the front and centre of the chamber, were the main focus of those attending the ceremony, the wives were seated in a similarly prominent position in full view of those present and had an equally important part to play as a witness to the ceremony and as a testament to the reputable masculinity and marital status of the governor. Witnessing the opening ceremony legitimised the enactment of the constitution, and both governors' wives and the members of the public present fulfilled this important duty. In addition to being a witness, governors' wives were also witnessed by the public during this event, both in person by those in attendance, and in the press by 
the public at large who read reports of the day's proceedings in local newspapers. In this way not only were governors seen to carry out their official functions, so were their wives.

Being present at the opening ceremony and being seen to be present were key elements in the part played by wives at the opening ceremony. It was uncommon for them not to attend the opening ceremony, and on the rare occasion they were absent from proceedings, their non-attendance was noted and commented on in newspapers. The presence of the wives at the opening of Parliament could even, according to the local press, impact on the number of ladies present at the ceremony. In 1890 when Lady Onslow advised that she would not attend the opening of Parliament due to being indisposed, the Otago Daily Times reported that, " $[t]$ he intending lady spectators had to digest their disappointment as best they might, and probably as a consequence their attendance was exceptionally small."71 The 'Girls' Gossip' column in the Evening Post made similar remarks in 1905 when it commented on Lady Plunket's attendance at the opening ceremony: not only was everyone "delighted" to see her there, the writer 'Priscilla' also stated that, "to speak truly, the function loses half its interest to women when the Governor is unaccompanied."72 Clearly, the presence of the wives at the opening of Parliament was keenly anticipated and, indeed, expected.

More than this, the presence of the wives legitimised not only the ceremony but also the governor in his role. It was because of their marriage to the monarch's representative that governors' wives attended the opening of Parliament and they were present as wives. In this manner, the marital bond was on display as much as constitutional proceedings. The wives were present as witnesses to proceedings but through their wifely status, the wives also acted to legitimise their husbands in the vice-regal role. A married man was respectable, responsible and trustworthy. On occasion, the vice-regal couple's children also attended the opening ceremony and sat with their mother throughout proceedings. Not only were the governors shown to be married men, their status as fathers was also emphasised through the

\footnotetext{
71 'The Opening Ceremony', ODT, 20 June 1890, p.2.

72 'Girls' Gossip', EP, 1 July 1905, p.15.
} 
attendance of their children, further adding to their credibility in the role of governor.

A number of historians have discussed marriage within the British Empire. For instance, in her history of interracial marriage in New Zealand, Angela Wanhalla illustrated the New Zealand government's deep involvement in intimate relations during the nineteenth and twentieth centuries. Although her focus was on interracial marriage, Wanhalla nonetheless made valid and important points about the nature of marriage in an imperial society, in particular, as a marker of civilised society. Wanhalla noted how marriage was used as an assimilationist tool in New Zealand, as a means of 'civilising' and bringing Māori into the British world. ${ }^{73}$ Here marriage was as much about intimate, affective relationships as it was a force for promoting the benefits of imperial civilisation. It was promoted as such by the Church Missionary Society in New Zealand, who performed marriages between Pākehā and Māori as a means of both 'civilising' Māori while simultaneously converting them to Christianity. ${ }^{74}$ Empire was thus built on ideas of family and marriage. Wanhalla also discussed the gender dimension of marriage, that is, of women as the civilising influence on men (both Māori and European) through marriage. Marriage to European women was beneficial to white men, making them more effective contributors to the colony both as labourers and as fathers, while "Māori men could be reformed by marriage to a white woman." 75 In this instance, white women were set up to be a moral influence on society.

Women as the moral authority in colonial society is a theme also discussed by Ann Laura Stoler in much of her work. ${ }^{76}$ Although Stoler's work is primarily concerned with examining the contest around race and intimacy in colonial society, it also looks at how white women were charged with protecting European culture against the colonised 'other'. As such, Stoler's work provides a means of understanding how European women were situated in the imperial project as the

\footnotetext{
${ }^{73}$ Angela Wanhalla, Matters of the Heart: A History of Interracial Marriage in New Zealand (Auckland: Auckland University Press, 2013), pp.24, 47, 109.

74 Ibid, p.24.

75 Ibid, pp.109-110.

${ }^{76}$ See for example: Ann Laura Stoler, Carnal Knowledge and Imperial Power: Race and the Intimate in Colonial Rule (Berkeley: University of California Press, 2002); Ann Laura Stoler, 'Making Empire Respectable: The Politics of Race and Sexual Morality in 20th-Century Colonial Cultures', American Ethnologist, Vol. 16, no. 4, 1989, pp.634-660.
} 
protectors of morality and civilised society. Stoler argued that male colonisers, "positioned European women as the bearers of a redefined colonial morality."77 European women were the guardians of European culture in the colonies and through their gender were vested with a specific female authority over domesticity and family life. Imperial culture was closely aligned with this Victorian ideal of family life, centred on the woman as wife and mother. Women were not the sole bearers of moral authority in the colonies; men also had a part to play. As noted by Penny Russell, "[i]mperial masculinity had a broader dimension than that implied in conquest alone."78 Masculinity in the Empire no longer referred exclusively to the acquisition and domination of land and peoples. Instead, a "domestic ideal of manliness, with an emphasis on moral rectitude, religious values, family and responsibility also had its place in colonial society."79 Marriage was the site of this idealised moral, civilised, imperial society.

As acknowledged leaders of colonial society, and as holders of an imperial office, governors and their wives can be understood as epitomising these ideals. Vice-regal office required that they be recognised as reputable and trustworthy members of society. For the governor, being married could help to prove his suitability for office. Having a wife vested him with respectability and spoke to his good character and success in life, as did having children. Marriage helped to legitimise his claim to holding the position. Here was a man who typified the masculine ideal - who better to have as governor? By being present at ceremonial, social and constitutional events, governors' wives helped to showcase the marital status of their husbands. The vice-regal office was as much a familial and marital office as it was a public one. It could almost be argued that marriage was a prerequisite of the vice-regal position.

The importance of marriage to the governor's position is indicated by the fact that between 1887 and 1926, all the men who served as governors in New Zealand, were married. Indeed, all save one of New Zealand's past governors and governors-

\footnotetext{
77 Stoler, 'Making Empire Respectable', p.640.

78 Penny Russell, 'Introduction', in Penny Russell (ed.), For Richer, for Poorer: Early Colonial Marriages (Melbourne: Melbourne University Press, 2004), p.6.

79 Ibid.
} 
general brought their spouses with them to Government House. ${ }^{80}$ Not only was a wife an aid in successfully carrying out the duties of the vice-regal position, she also, through the public display of their marital bond, gave the governor respectability and moral authority in his position. He was seen and understood as fit for public office. This public display of marriage and family life can be seen throughout many of the engagements in which governors and their wives were key actors.

One of these engagements was the swearing in of the new governor. Upon arriving in New Zealand the first order of business was for the incoming governor to take the oaths of allegiance and of office. This ceremony was held directly after the governor's landing in Wellington. Following official addresses of welcome from various government officials and a procession through the city to Parliament, the oaths were administered in full view of the public. As with the opening of Parliament, the governor's wife did not play a significant part in the ceremony, but once again, she was present, a witness to the occasion. When Lord Onslow took the oaths of allegiance and of office he was accompanied by his aides, Sir James Prendergast (then Chief Justice and Administrator of the Government), Sir William Fitzherbert (Speaker of the Legislative Council), the heads of departments, military staff, and his wife and children.81 Likewise, on 7 June 1892 when the Glasgows arrived in Wellington to begin their vice-regal term, Lady Glasgow accompanied her husband from the ship for both the landing ceremonies and the oath taking. ${ }^{82}$ Lord Plunket took the oaths at the entrance to Parliament, witnessed by a large crowd of Wellingtonians and accompanied by his wife, sister, and aides. ${ }^{83}$ The oath taking, with one exception in 1910 (see below), follows this formula right through to 1924, when the last governor included in this study - Sir Charles Fergusson - participated in the ceremony with his wife by his side. ${ }^{84}$

Again, the oath taking indicates the role of witness played by governors' wives in ceremonial events. As with the opening of Parliament, the wives did not participate in any specific way. Whereas the governors occupied a prominent

\footnotetext{
80 Dame Catherine Tizard, the country's first female governor-general, was not married when she accepted the post in 1990. McLean, p.326.

81 'Second Edition. Reception of the Governor', EP, 2 May 1889, p.3.

82 'Arrival of the New Governor', ODT, 8 June 1892, p.2.

83 'Our New Governor', ODT, 21 June 1904, p.3.

84 'Lord Liverpool', ODT, 29 July 1917, p.5; 'Taking the Oaths', EP, 27 September 1920, p.8; 'Swearingin Ceremony', EP, 13 December 1924, p.8.
} 
position at the front and centre of proceedings, the wives performed a secondary role, standing with their husbands during proceedings. Once more governors' wives were bearing witness to a constitutional event. In a country without a formal written constitution, the acts of government and of being seen to engage in these events carried weight. Constitutional ceremonies served to show government in action, as being followed to the letter. Such occasions were also a thoroughly public affair, in which the governors demonstrated that they would perform their office in the company of and with their wives at their side, at once a husband and a man fit for public office. These proceedings, and their repetitiveness and sameness over time, also served to emphasise the stability, continuity, and longevity of the British monarchy.

Lord Islington's oath taking ceremony provides one example where the governor's wife was not present in support of her husband during this ceremony. The wealthy Baron Islington was sworn in as Governor of New Zealand on 22 June 1910 shortly after his arrival in Wellington. The Prime Minister Joseph Ward was on hand to greet him as he stepped off the ship, and from there they proceeded to the parliamentary buildings where Lord Islington took the oaths of allegiance and office in the presence of large crowds. ${ }^{85}$ His wife, Lady Islington was not due to arrive in New Zealand until August and so was not present for this ceremony. Despite her absence Lady Islington was far from forgotten. Lord Islington mentioned her in his reply to the Mayoral address, and the Prime Minister, upon the completion of the oath taking, called for three cheers each for both the Governor and Lady Islington. ${ }^{86}$ When Lady Islington did finally arrive in New Zealand two months later on 25 August 1910, Wellington provided a public welcome. The Governor, along with an official party made up of the Prime Minister and his wife Lady Theresa Ward, the Mayor and Mayoress (Thomas and Georgia Wilford) and some government ministers received Lady Islington and her daughter upon their arrival and Lady Ward presented Lady Islington with a bouquet of flowers. ${ }^{87}$

This episode serves to illustrate that although the physical presence of governors' wives was not a required component of constitutional ceremonies, the

\footnotetext{
85 'The New Governor', ODT, 18 July 1910, p.3 (supplement).

86 Ibid.

87 'Lady Islington', EP, 25 August 1910, p.7.
} 
wives' presence, and all that it represented through the display of the marriage, was nonetheless desirable. Lady Islington, while physically absent from proceedings was there in word, her presence invoked by others. The marital bond was still on display on this occasion. The presence of governors' wives, whether physical or invoked by others, was indicative of the importance of the marriage bond to the carrying out of governors' official duties. It gave the governors a sense of respectability and reliability in the eyes of the public. The marriage bond was also how governors' wives derived their own privileged and honoured position in society. Marriage served both governors and their wives in establishing their position, and its display was an important element in the carrying out of their vice-regal duties.

This display of marriage in the vice-regal role is similarly illustrated in the social engagements attended or hosted by the governor and his wife. As a general rule, when attending or hosting balls, garden parties, receptions and other social events, the governor and his wife went as a pair. Likewise prominent men of New Zealand came to these events with their wives. Such events were ones to which men and women were invited as married couples. They were also occasions which encouraged and facilitated the mixing of men and women in a social environment. The nature of these events removed men and women from the professional and domestic spaces which normally defined them to an environment where the different social context relied on their marital status as a marker of their identity.

Specific social events were attended by varying sections of society. McLean, in his work on New Zealand's governors, explained that receptions and balls were reserved for a more select group of New Zealand society and that the majority of those "took place in town halls when touring or in Wellington during the 'ball season'."88 There was always a ball at Government House for the monarch's birthday, and other balls were often hosted in honour of favoured groups, patriotic societies, or the military. ${ }^{89}$ For those not part of the cream of colonial society, and therefore unlikely to receive an invitation to a Government House ball, garden parties provided their best hope: “[p]eople who signed the visitors' book at the gatehouse and had not been invited to anything better had a good chance of being

88 McLean, p.130.

${ }^{89}$ Ibid. 
invited to a garden party." 90 Social events hosted by the vice-regal couple were a chance for colonial society to mix as much as they were a chance for men and women to mix. Both marital and class status were defining features of these engagements.

Social events were also subject to seasonal influences. The opening of Parliament normally marked the start of the winter social season as it meant the governor was in residence and, thanks to the arrival of politicians and their wives to the city, residents of Wellington could expect a flurry of balls, 'at Homes', dinner parties, and outings to the opera or theatre. ${ }^{91}$ Other events, such as the death of royalty, whether British or not, could also shape the social season. Following the death of King Edward VII in 1910, a period of full Court mourning was imposed, and then-Governor Lord Islington and his wife were unable to give any entertainments for the first four months of their term in office. ${ }^{92}$ Likewise, Lord and Lady Fergusson were hampered twice in their hosting duties by the deaths of Queen Alexandra, widow of King Edward, in 1925 and of the Emperor of Japan a year later. ${ }^{93}$

Government House balls were among the most anticipated of social events in New Zealand between 1887 and 1926 and they were often held to celebrate imperial occasions. Reports of the balls were carried in newspapers and detailed the guests, decorations, the fashion, dining and proceedings for those who did not receive an invitation. In May 1898 the Ranfurlys gave a large ball in honour of Queen Victoria's birthday at Government House. As they had arrived in the colony in August the previous year, this was their first time hosting a royal birthday ball and so the event was of considerable importance for confirming to the public their skills as hosts and vice-regal representatives. The reception they received in the Evening Post the following day indicates they were successful: "last night's was one of the most delightfully perfect balls ever given in Government House."94 Guests were received

\footnotetext{
90 Ibid.

91 Martin, p.43.

92 'Personal Matters', EP, 1 October 1910, p.5. King Edward had died in May 1910 at which point full Court mourning was imposed. It was not lifted until 1 October 1910, at which point Lord and Lady Islington were able to resume entertainments, although "large balls" were still forbidden.

93 'The Governor-General', NZH, 28 December 1925, p.8; 'The Governor-General', NZH, 28 December 1926, p.10.

94 'The Birthday Ball', EP, 27 May 1898, p.2. The correspondent for the Press was equally complimentary of the ball, calling it "an assured and brilliant success" and noting the trouble taken by
} 
by the Governor's ADCs as they arrived, and at nine thirty in the evening, "the Viceregal party came downstairs and walked up the rooms to the strains of the National Anthem."95 The Governor and Lady Ranfurly then took part in the official set to open the ball and among those who joined in this dance were the Premier, Richard Seddon, and his wife Louisa. ${ }^{96}$

Marriage and family life were often on display at these social events. At the Queen's birthday ball described above, the Ranfurlys entered together, as a married couple, while they opened the first dance with married couples, among them the Seddons. A few years later in 1902 the Ranfurlys held a Government House ball to celebrate the coronation of King Edward VII and once again marriage was a crucial component of the event. ${ }^{97}$ Hundreds were invited from around the colony, with the list of guests printed in the newspaper covering close to two columns. A notable feature of this invitation was the marital status of those listed. Given alphabetically, the list named all those invited to the ball. Married couples predominated, the husband named first, followed by his wife. That guests were invited as husbands and wives indicates the importance of marriage and family life to society at this time, and that the list was made public also points to the social importance of invitations to Government House balls, as well as the public identification of women by their marital status.

A similar course of action was observed by the Islingtons when they hosted a ball in celebration of the 1911 coronation of King George V at Government House. As with the previous coronation ball hosted by the Ranfurlys almost a decade earlier, the guest list was long - 800 were invited although newspaper reports suggested that owing to bad weather only six to seven hundred attended. ${ }^{98}$ The playing of 'God Save the King' announced the entrance of Lord and Lady Islington to the ball, and they immediately opened the dancing with several other couples. ${ }^{99}$ All the women and men who participated in this first dance were married. Again, the guest list was made public in the newspapers, and again guests were invited as married couples.

the Governor and in particular Lady Ranfurly in their hosting duties: 'The Birthday Ball in Wellington', Press, 27 May 1898, p.5.

95 'The Birthday Ball', EP, 27 May 1898, p.2.

96 Ibid.

97 'The Coronation Ball', EP, 7 August 1902, p.5.

98 'Coronation Ball', ODT, 29 June 1911, p.7; 'Coronation Ball', EP, 28 June 1911, p.9.

99 'Coronation Ball', EP, 28 June 1911, p.9. 
This particular coronation ball also provided an opportunity for debutantes to 'come out' to society. ${ }^{100}$ Being a debutante signalled that "the newly introduced young woman was now ready for marriage", 101 and the inclusion of this custom at a Government House ball further indicated the importance of marriage to society at this time. Despite the passage of time since the previous coronation ball, the form and custom of events followed the same path, providing a sense of continuity and ritual to social life. This steadiness in social life and in the presentation of marriage in society and to the public over time is suggestive of the importance of rituals and tradition to the British Empire and the position of the governor and his wife in upholding and presenting that tradition.

Garden parties, with their more inclusive guest lists and day time hours, provided a more relaxed and casual space for socialising. Governors and their wives could move freely with their guests, their children often attended, and the event was marked by less formal etiquette than balls or other ceremonies. Sometimes rain did interfere with the event, and on one occasion when this did happen the party moved inside Government House to the ballroom. ${ }^{102}$ On 27 October 1891, while halfway through their term in office, the Onslows gave a garden party at Government House. An article in the Press the following day provided details of the affair. Starting at 3 o'clock, the guests were received upon their arrival by Lord and Lady Onslow, who, once they had completed this duty, mingled freely with their guests on the tennis lawn. A band played selections of music for the guests and a large marquee was the setting for afternoon tea. The vice-regal couple's children attended the garden party also, their two daughters dressed in simple white embroidered dresses while their month-old baby son, born in New Zealand, "came in for a full share of admiration from all the ladies." The Press commented on "the charm and amiability of manner" of the governor and his wife in their dealings with colonial society. ${ }^{103}$

In May 1922, halfway through their term in office, the Jellicoes gave a garden party at Government House which was marked by a relaxed formality. They received their guests on the lawn in front of the terrace, and their guests then passed indoors

\footnotetext{
100 Ibid.

101 Lillie Le Dorré, 'Dancing Debs: Debutante Balls in Twentieth Century New Zealand, c.1920-1975',

BA (Hons) research essay in History, Victoria University of Wellington, 2012, p.1.

102 'Garden Party at Government House', NZH, 21 April 1900, p.5.

103 'Garden Party at Government House', Press, 28 October 1891, p.5.
} 
to the ballroom and dining room where they could find refreshments. The New Zealand Herald noted that guests were free to roam about the various sitting rooms of Government House during the garden party. Later that afternoon, an orchestra entertained with a programme of music. ${ }^{104}$ Both this event and the Onslows' garden party were marked by the free movement of not only the vice-regal couple but their guests also, and other than receiving guests there were few formalities to be observed. Unlike royal birthday or coronation balls which maintained a clear imperial link, garden parties provided an opportunity for a relaxed mixing of society and did not require the strict observance of formality evident in other social events. Although governors and their wives were still vice-regal representatives at garden parties, the absence of a clear imperial connection or purpose for the event lessened the requirement for pomp and ceremony seen elsewhere in the vice-regal social calendar.

What is distinct in these social occasions is that the governors and their wives were always present as a married couple. In the case of the garden party hosted by the Onslows, family life was also clearly on display to those who attended and who read about the event the next day. Whether the event was a formal social occasion or a more relaxed affair, the governors and their wives attended together. They were almost always on public display as a married couple, and on occasion as parents, and this trend continued throughout the late nineteenth and early twentieth centuries. Not only was this apparent at constitutional and social events, it was also a feature of important imperial events.

When New Zealand celebrated the granting of Dominion status on 26 September 1907, moving "from the knickerbockers of colony to the long trousers of Dominion",105 the Governor, Lord Plunket, played an important part in both the ceremonial and social celebrations in Wellington. At a short morning ceremony at Parliament he invited the Prime Minister Sir Joseph Ward to read the Proclamation declaring the change from colony to dominion, before he himself read a message of congratulations from the King. ${ }^{106}$ Lady Plunket accompanied her husband to the ceremony and, although she played little part in the event, as with the ceremonies

\footnotetext{
104 'Vice-Regal Garden Party', NZH, 19 May 1922, p.8.

105 'Dominion Day', EP, 26 September 1907, p.7.

106 Ibid.
} 
for the opening of Parliament and the taking of the oaths of office she was nevertheless a witness to the occasion. The remainder of the day's events offered a similar part for Lady Plunket to play: with her husband she hosted a lunch at Government House for members of Parliament, attended the trooping of the colours at Newtown Park in Wellington, and hosted an afternoon reception for 2,500 guests at Government House. ${ }^{107}$ On these occasions she was present as both the Governor's wife and as a witness to proceedings. Once again, marriage was the critical element on display.

On 20 June 1887, Queen Victoria marked fifty years on the throne, and celebrations for her Golden Jubilee were held around the Empire. In New Zealand, towns and cities throughout the colony held events to mark the occasion. 108 The capital celebrated the jubilee in various ways, with church services, a carnival and sports festival hosted by the city's Friendly Societies, a procession through the city streets, a concert, illuminations on buildings, a Government House levee, and a Government House ball. ${ }^{109}$ The Governor and his wife Lady Jervois attended the jubilee service at St Paul's Pro-Cathedral in Wellington on the night of the jubilee and His Excellency also held a full dress levee in honour of the jubilee at Government House to which many foreign consuls, politicians, and other leading citizens were invited. ${ }^{110}$ In addition, the tower of Government House was illuminated with electric light for the evening: "[it] was illuminated on each face by a square rim of electric globes, with the letters V.R. glowing in the middle. The tower could be seen from almost every part of the city, and the effect was very fine."111 Later that week, the Governor and Lady Jervois hosted a ball at Government House in honour of the occasion. According to the Evening Post, it was "one of the most brilliant assemblages ever known in Wellington, and was greatly enjoyed by the guests, who must have numbered fully 800. Dancing was kept up till nearly 2 o'clock."112 As with the celebrations for the granting of dominion status, the Governor and Lady Jervois attended and hosted jubilee celebrations as husband and wife. However, while the

\footnotetext{
107 'Dominion Day in the Capital', ODT, 27 September 1907, p.6; 'Spectacle at the Park', EP, 26 September 1907, p.8

108 'The Jubilee Celebrations', EP, 22 June 1887, p.2.

109 'The Jubilee of Her Majesty', EP, 21 June 1887, p.2; EP, 23 June 1887, p.2, column 4.

110 'The Jubilee of Her Majesty', EP, 21 June 1887, p.2; 'The Jubilee Celebration', EP, 18 June 1887, p.2.

111 'The Jubilee of Her Majesty', EP, 21 June 1887, p.2; EP, 23 June 1887, p.2, column 4.

112 EP, 23 June 1887, p.2, column 4.
} 
marriage bond was an important feature of this imperial celebration, it also provided Lady Jervois with an opportunity to use her position for a wider cause.

In addition to attending ceremonies in connection with the jubilee and hosting a ball at Government House, in the months leading up to the jubilee Lady Jervois worked to create a 'Queen's Fund' to raise money for the benefit of women in the colony. In Wellington on 27 April 1887, Lady Jervois presided over a meeting of ladies - among them the Mayoress, Lady Stout and Lady Vogel - to discuss how the ladies of Wellington could best celebrate the upcoming jubilee. ${ }^{113}$ The meeting resolved to form committees to "decide in what manner the efforts of the ladies might be most effectively applied."114 A month or so after the meeting, Lady Jervois wrote a letter (later published in various newspapers) to ladies of other provinces in New Zealand in which she explained that to commemorate the jubilee in Australia a 'Queen's Fund' had been started “to which women of all classes are invited to contribute in sums varying from a penny to a pound, and it is proposed that the interest of the money shall be used in some way for the benefit of women."115 Lady Jervois advocated setting up the same fund in New Zealand, with each province able to choose where best to spend the money, so long as the object of helping women was retained. 116 The success of the New Zealand 'Queen's Fund' varied across the provinces, with some more keen than others to participate. ${ }^{117}$ But regardless of its outcome, the Fund demonstrates how the wives' could extend their position in viceregal ceremonial from witnessing and displaying marriage, to one that was more central and memorable.

Queen Victoria's Diamond Jubilee was celebrated with as much fervour as her Golden Jubilee ten years earlier. However, in June 1897 Government House was occupied by Sir James Prendergast and his wife, Mary, in a caretaker role. Whenever there was a period of absence between the departure of one governor and the

\footnotetext{
113 'The Queen's Jubilee', EP, 28 April 1887, p.4.

114 Ibid.

115 'The Queen's Jubilee', EP, 4 June 1887, p.2.

116 Ibid.

117 In Auckland, a 'Queen's Fund' was established which would be devoted to "the assistance of women of all classes who are in distress", while in Dunedin the scheme would raise funds to aid convalescents. In New Plymouth the scheme was not well received, and in Ashburton only one lady attended a meeting in connection with the fund. See, 'The "Queen's Fund"', NZH, 8 June 1887, p.5; ODT, 25 June 1887, p.2, column 4; EP, 15 June 1887, p.2, column 8; 'Borough Councils', Press, 13 July 1887, p.5.
} 
arrival of a new governor, an Administrator of New Zealand stepped into the position and the vice-regal residence. Prendergast filled this role several times between 1875 and 1899 and was responsible for performing all vice-regal duties, political and social. ${ }^{118}$ From February 1897 when the Earl of Glasgow left the colony until August 1897 when the Earl of Ranfurly arrived, Prendergast was the Administrator, and it was he, along with his wife, who took on the vice-regal duties during the June celebrations of Queen Victoria's Diamond Jubilee. ${ }^{119}$

The death of Queen Victoria on 22 January 1901 offered another opportunity for the governor's wife to take on a prominent position in an imperial event. At this point in time, the Earl and Countess of Ranfurly were in occupation at Government House. Lady Ranfurly happened to be in the United Kingdom at the time of the Queen's death, having left Wellington on 11 October 1900 with her two daughters for a visit home. ${ }^{120}$ As such, she acted as New Zealand's representative at the funeral. On her return voyage, while in Melbourne before the last leg of her trip to New Zealand, she gave an interview describing her experience. Lady Ranfurly related how she heard about the seriousness of the Queen's illness from a society lady at a party in London three weeks before her death, and that she was in Dublin when the news broke. She returned immediately to London, where, in her words:

As you drove about the streets there was no particle of colour to be seen; absolutely the very poorest people, poorer than any class you see out in the colonies, had dressed themselves in black. All that week before the funeral it seemed as if there was a silence in the air that it had not before ... Of course, all invitations to functions, both public and private, were cancelled. It was as if the wheels of society had absolutely stopped. ${ }^{121}$

Of the funeral itself, Lady Ranfurly expressed her appreciation at being conferred the honour of representing New Zealand, and detailed the proceedings. She also mentioned that the wreath sent by New Zealand (made of palms and arum lilies) was "very beautiful". 122

118 Grant Morris, Prendergast: Legal Villain? (Wellington: Victoria University Press, 2014), pp.172177.

119 Ibid, p.175; 'To-Morrow's Programme in Wellington', EP, 21 June 1897, p.6; 'To-Night's Ball at Government House', EP, 23 June 1897, p.6.

120 'Departure of Lady Ranfurly', Press, 12 October 1900, p.6.

121 'Our Representative at the Queen's Funeral', Press, 7 May 1901, p.3.

122 Ibid. 
The Queen's passing served as an opportunity for Lady Ranfurly to act as a representative of New Zealand at the funeral. It served also as a reminder that death was often an unscheduled event, and could interrupt even the vice-regal calendar. It seems likely that Lady Ranfurly was asked to represent the colony at least partly through convenience as she was already in Britain at the time of Victoria's death. Yet, remembering that governors' wives held no official position in vice-regal office, that Lady Ranfurly was asked to represent the colony at the funeral indicates the high status and position she nonetheless enjoyed. This is particularly so given that New Zealand did at the time have an official representative resident in London William Pember Reeves, Agent-General for New Zealand (a position which in 1905 became that of High Commissioner). ${ }^{123}$ What this event suggests is that, though the position of governors' wives was due to the office held by their husbands, they were still recognised as figures of authority and elite status at this time.

The status and recognition afforded to governors' wives seems generally to have grown over time, as witnessed by the increasingly frequent use of the honorific 'Her Excellency' in the New Zealand press. While governors were known as 'His Excellency' by right, around the Empire in the nineteenth century, the use of the honorific in reference to governors' wives was under debate. In April 1889, the New Zealand Herald reported on a debate that took place in Melbourne society surrounding the use of the term 'Excellency' to refer to a governor's wife. The debate arose out of the insistence by Lady Blake, wife of the new Governor of Jamaica, that she be addressed as 'Excellency', something the local Jamaican population apparently refused to do. According to the Herald, the Australian newspapers at the time confirmed that 'Her Excellency' was the correct term, as used by the Colonial Office. ${ }^{124}$ An article in the Evening Post also raised the question of whether the wife of a governor could use the term and noted a direction on the matter from Debrett and Burke (of the famous directories of Britain's Peerage) that a governor's wife could be styled 'Her Excellency' by courtesy, but only when resident in the colony during her husband's term in office. ${ }^{125}$ Controversy over the use of the term seems

\footnotetext{
${ }^{123}$ Ibid; Keith Sinclair, 'Reeves, William Pember', Dictionary of New Zealand Biography, Te Ara - the Encyclopedia of New Zealand, updated 14 January 2014; http://www.teara.govt.nz/en/biographies/2r11/reeves-william-pember; accessed 28 May 2015. ${ }_{124} \mathrm{NZH}, 18$ April 1889, p.5, column 1.

$125 E P, 23$ September 1886, p.3, column 2.
} 
to have been in relation to the status that such a term conferred on the recipient and debates about whether the wife of a governor, having no official position in the viceregal establishment, was deserving of such elevation of rank. In the New Zealand context, no debate over whether the term should be used appears to have occurred, although it is interesting to note that its usage by the New Zealand press between 1887 and 1926 did change significantly.

When Lady Jervois was wife of the governor in the 1880s, it was rare for the New Zealand press to refer to her as 'Her Excellency'. On only two occasions across the four newspapers included in this study was the honorific used. ${ }^{126}$ Likewise for both Ladies Onslow and Glasgow, in New Zealand from 1889 to 1892 and 1892 to 1897 respectively, the term was scarcely used.127 During the years that Lady Ranfurly was in the colony (1897 to 1904), usage of the term had increased slightly, but it was not until Lady Plunket arrived in 1904 that usage of 'Her Excellency' increased substantially in the New Zealand press. ${ }^{128}$ The reason for this shift is unclear, but given that it became almost commonplace while the Plunkets were in office, there is reason to believe that usage was related to the status afforded by the term. New Zealand changed from a colony to a dominion in 1907 when Lord Plunket was governor, roughly coinciding with the change in the use of 'Her Excellency'. As the wife of a governor of a dominion, rather than a colony, perhaps the New Zealand press felt that Lady Plunket was more deserving of the honorific. Alternatively, the shift in usage could be the result of a growing acknowledgment of the part played by governors' wives in carrying out the duties of vice-regal office. Equally, the lack of debate over the term by the New Zealand press is perhaps itself testament to the status afforded governors' wives in New Zealand. Regardless, the changing use of the

\footnotetext{
${ }_{126} E P, 1$ July 1887, p.2, column 4; EP, 2 October 1886, p.2, column 6.

127 'Her Excellency' was used twice to refer to Lady Onslow during her time in New Zealand (see $N Z H$, 17 February 1890, p.5, column 2; NZH, 30 January 1890, p.6, column 2), while the term was used three times in reference to Lady Glasgow (see Iolanthe, 'Lady Correspondents', Press, 25 July 1895, p.2, column 4; 'Reception to Lord and Lady Hopetoun', EP, 2 March 1893, p.2; EP, 8 July 1892, p.2, column 4.)

${ }^{128}$ Lady Ranfurly was referred to as 'Her Excellency' five times: 'Zenana Institute Exhibition', Press, 4 September 1897, p.8; 'Personal Items', NZH, 9 November 1897, p.6; ODT, 27 June 1901, p.5, column 4; 'Reception at Government House', NZH, 12 June 1901, p.6; 'The Veteran's Home', NZH, 26 May 1903, p.6, column 7. For just a few examples of the press referring to Lady Plunket as 'Her Excellency', see 'An Interview with Lady Plunket', Press, 26 August 1904, p.6; Priscilla, 'Ladies' Column', EP, 7 September 1907, p.15; ODT, 9 October 1909, p.9, column 4.
} 
honorific in reference to governors' wives in New Zealand suggests that public recognition of the part they played in vice-regal life increased over time.

Inasmuch as the changing use of labels signified a shift in public understanding of the part played by governors' wives in New Zealand, the fact remains that they held no official position. The playing of the national anthem at ceremonial events is evidence of this fact. The national anthem, until 1977 'God Save the Queen/King',129 featured heavily in vice-regal ceremony and acted as a notice for the arrival of the governor as well as of his departure. It was played at the opening of Parliament and when the governor first arrived in the colony. It was also played when he arrived in towns while on tour, upon his arrival and departure at social engagements such as balls, or when attending the theatre or opera. ${ }^{130}$ The anthem signalled that the representative of the Queen or King was present. As such, it was only ever played when the governor attended an event. Governors' wives, having no official position of their own and being in New Zealand by virtue of their marriage, were not afforded this honour when they attended an event without their husbands. However on one occasion when Lady Islington attended a Young Women's Christian Association meeting in 1912 the anthem was played as she left. ${ }^{131}$ This appears to have been an anomaly rather than marking a shift in how governors' wives were acknowledged, however, as no other incident of this kind can be seen to have occurred between 1887 and 1926.

The position of governors' wives in vice-regal ceremonial between 1887 and 1926 is one marked largely by continuity but which also hints at a subtle change. Throughout these years the official duties of the governor remained constant, as did the way in which he and his wife participated in them. In constitutional, social and imperial ceremonies they carried out the same actions. For the wives, this often involved little more than being present at, and a witness to, the ceremony, an action

\footnotetext{
${ }^{129}$ In 1977 the anthem currently used most often by New Zealand ('God Defend New Zealand') was lifted to anthem status alongside 'God Save the Queen': 'Announcement of the Adoption of National Anthems for New Zealand', 21 November 1977, New Zealand Gazette, no. 117, 1977, p.3029.

130 See for example: EP, 29 January 1883, p.2, column 5; 'The Governor in Dunedin', Press, 16 November 1889, p.6; 'Northern Club Ball', NZH, 8 April 1891, p.5; 'Garden Party', Press, 5 November 1910, p.10; 'Ladies' Night', EP, 12 July 1924, p.9.

131 'Women in Print', EP, 5 August 1912, p.9.
} 
that helped to legitimise not only the ceremony itself, but also the governor in his own position. The wives' actions in these events continued and were repeated over the years, and the way in which they were carried out changed little, if at all. What did change was the recognition afforded to governors' wives in their position. A gradual shift in the public recognition given to governors' wives - as indicated by Lady Ranfurly acting as New Zealand's representative at Victoria's funeral, as well as the growing use of 'Her Excellency' by the press - hints at an expansion over time of her position as a figure of public interest and authority.

Marriage was also a crucial and defining feature of the vice-regal lady's position in New Zealand society. It was how she came to be in New Zealand and it coloured all her interactions while carrying out her duties. Governors' wives were exactly that - wives. Although they had substantial power and influence, and were considered leading members of society, this elevated status derived from their husband's own power and influence as the monarch's representative. In addition, through marriage, and specifically the public display of marriage, the governor was understood to be a respectable, honourable, trustworthy man. Having a wife conferred on the governor characteristics that reinforced his suitability for the position. This is not to say that governors' wives were understood as little more than women carrying out their wifely duties. Rather, they were an acknowledged factor in the success or otherwise of their husbands' terms in office between 1887 and 1926. Although there was much that remained static in the way in which governors' wives participated in vice-regal ceremonies and social life, at the same time, it was this stability that helped to confirm the position of governors' wives in the imperial world.

There is an element of the performative here, in that the repetition and constancy inherent in the wives' position can be understood to have helped create and confirm it. Governors' wives always performed the same duties and they always carried out these duties in the same manner. Through this repetition, through the carrying out of the rituals of the constitution and society and the part played by the wives in these rites and formalities, governors' wives affirmed their place in viceregal office. Although the position occupied by governors' wives was (and still is) one marked by traditions, rituals, and formality which by their very nature do not 
easily accommodate change, the performative element apparent in the position suggests that it was nevertheless a position that governors' wives could influence, alter, and create through their own actions. 


\title{
Chapter Two
}

\section{Voluntary Welfare and Women's Imperialist Organisations}

\begin{abstract}
Though the wife of a colonial Governor has no constitutional status she can often play an important part in the social life of the community in which her lot for the time being is cast. And in this way she may prove an invaluable factor in the promotion of the intangible ties which help to bind the British dependencies to the Motherland. ... [Lady Ranfurly] closely identified herself with every movement appealing to womanly aid and sympathy, and calculated to advance the moral and material welfare of those in whose interests it was originated. 132
\end{abstract}

So stated the New Zealand Herald in a brief column praising Lady Ranfurly's contributions to the colony shortly after her return to Britain in 1903. In the late Victorian period and continuing into the Edwardian era and beyond, governors' wives in New Zealand played a significant and often active part in the local community. They engaged in welfare work, gave their names and time as patrons to various associations, and participated actively in promoting their chosen causes through practical work such as fund raising, convening meetings, and giving addresses.

Starting in the 1880s and continuing into the 1920s, governors' wives in New Zealand became involved in various organisations, not only those concerned with voluntary welfare, but in particular those connected with women and children and those serving to highlight or contribute to a specific national or imperial cause. Their actions occurred in an environment where New Zealand women were actively seeking political rights through organisations such as the Women's Christian Temperance Movement and the National Council of Women.133 Exploring what organisations governors' wives became involved in, and what part they played in them is one of the key concerns of this chapter. As such, it looks at several of the organisations with which governors' wives were involved. In particular, the chapter takes a close look at three of the most notable groups across these years including the Girls' Friendly Society, the Royal New Zealand Plunket Society and the Lady

\footnotetext{
132 'The Countess of Ranfurly', NZH, 16 November 1903, p.4.

133 Charlotte Macdonald, The Vote, the Pill and the Demon Drink: A History of Feminist Writing in New Zealand 1869-1993 (Wellington: Bridget Williams Books, 1993), pp.32-36.
} 
Liverpool Fund. Additionally, the chapter is concerned with the ideas about women's place in society that were conveyed by the organisations governors' wives advocated, and what such associations indicate about governors' wives' own opinions on the subject.

Studies of governors' wives in the period from the 1880s to the 1920 s have focussed on two elements - women's voluntary welfare activity and the growth of women's imperialist organisations. ${ }^{134}$ In particular, existing studies centred in the late Victorian and Edwardian eras have considered the involvement of governors' wives in these two areas as indicators of a 'new' kind of vice-regal woman, one who was more independent and willing to engage in imperial projects, and whose duties were no longer confined to participation in the social and ceremonial side of viceregal responsibilities. ${ }^{135}$ These previous studies provide a base from which to further examine these two phenomena and how they relate to vice-regal life. Bringing the study into the New Zealand context also provides an opportunity to examine how both women's charitable work and female imperialism functioned in a colonial environment which was geographically distant from Britain, but where emotional ties to the Empire remained strong.

The nineteenth century has been described as "the golden age of voluntary welfare in Britain."136 Rapid industrialisation combined with urbanisation and an increase in religious feeling provided the necessary conditions for such welfare to exist.137 Voluntary welfare activity was visible across all classes and at both the national and local level, and its subjects of charity were diverse - prisoners, orphans, prostitutes, the sick, the homeless, and animals were all recipients of charity in nineteenth-century Britain. ${ }^{138}$ Such activity existed in an environment where welfare provided by the government was considered in an increasingly negative light. Since 1601, those who were destitute had been entitled to relief under the

\footnotetext{
134 See, in particular, McLeish, 'Sunshine and Sorrows'; Andrews, 'The Great Ornamentals'; Oppenheimer, "'Hidden under many bushels"'; Oppenheimer, 'The "imperial" girl'.

135 McLeish, p.257; Andrews, pp.1-2.

136 Margaret Tennant, The Fabric of Welfare: Voluntary Organisations, Government and Welfare in New Zealand, 1840-2005 (Wellington: Bridget Williams Books, 2007), p.22.

137 Ibid.

138 Ibid, p.23.
} 
Poor Law Act, a piece of legislation which made communal contributions to those who were in need of aid compulsory. ${ }^{139}$ But this law was amended in 1834 and the era of the 'New Poor Law' began. The new law applied the principle of 'less eligibility' (a concept in which aid administered to those in need should be less 'eligible' or attractive than what one could expect to live off on the lowest wages) to publicly funded assistance. ${ }^{140}$ As part of this reform, 'outdoor relief' (that given directly to those in need in the form of money, clothes, food, or other goods) was discouraged and workhouses established. ${ }^{141}$

In New Zealand, ideas about welfare were brought to the country as part of settler colonisation but conditions in the colony meant that they took on a distinctive shape and form. The Poor Law was resisted and indeed never established in New Zealand. Despite this reluctance to establish systems to provide welfare, the need for such aid inevitably arose in the new colony and some government initiatives were put in place during the years following 1840 to deal with this demand. Early initiatives included establishing public hospitals in 1846, and putting in place systems to deal with those deemed mentally ill, along with measures to compel close relatives to contribute towards the support of destitute persons. ${ }^{142}$ The provinces also took on responsibility for local welfare from the mid-1850s until their dissolution in 1876, with each province dealing with the needs of the sick, the poor, and the destitute to varying extents. ${ }^{143}$ The actions of the provinces were diverse, but overall were marked by the nineteenth-century philosophy of family responsibility and individual self-help along with voluntary charity by private citizens.

In the final decades of the nineteenth century the central government began to intervene in the provision of welfare to colonists in a systematic form. The Hospitals and Charitable Institutions Act 1885 was a significant piece of legislation which established a system for administering welfare throughout the colony. The

\footnotetext{
139 Ibid.

140 Ibid.

141 Ibid.

142 Margaret Tennant, Paupers and Providers: Charitable Aid in New Zealand (Wellington: Allen \& Unwin, 1989), p.13.

143 David Thomson, $A$ World Without Welfare: New Zealand's Colonial Experiment (Auckland: Auckland University Press with Bridget Williams Books, 1998), pp.84-89; Tennant, Paupers and Providers, pp.14-22.
} 
Act created a national system of hospitals and charitable aid boards; provided funding made up from local body rates, voluntary donations and central government subsidies; and allowed for approved voluntary organisations to incorporate under the Act and apply for public money. ${ }^{144}$ Essentially, the Act created an intermediary between central government and those in need of welfare, and it left the decision as to how aid was to be administered up to the individual hospital and charitable aid boards. The Old Age Pension Act 1898 was another significant piece of legislation which marked further intervention by the government into welfare, and additional developments in the twentieth century including legislation providing pensions to widows (1911), miners (1915), victims of the influenza epidemic (1918), and the blind (1924) followed. ${ }^{145}$ Despite these developments the strength of nineteenthcentury values of self-reliance and individual responsibility, coupled with the idea that only the most deserving of the poor should receive aid, meant that the early decades of the twentieth century continued to reflect nineteenth-century welfare policy and that welfare provision was uneven across the country. ${ }^{146}$ It was not until the election of the Labour government in 1935 that wholesale change to government-provided welfare began, creating the conditions for a welfare state to develop in the mid-twentieth century.

Throughout this era of meagre government involvement in the provision of welfare, those in need of aid were helped by the many church and charitable societies which arose in the nineteenth and early twentieth centuries, among them the Young Men's (and Women's) Christian Associations and the St. Vincent de Paul Society. ${ }^{147}$ In addition to these charitable organisations, local benevolent societies, such as the Onehunga Ladies' Benevolent Society (1857) and the Auckland Ladies' Benevolent Society (1863) were established and financed by both annual members' subscriptions and funds raised through concerts, bazaars, sporting events and soirées. ${ }^{148}$ Many voluntary charitable organisations and benevolent societies relied on government subsidies to survive, gained either directly from the government or through the hospitals and charitable aid boards - the classic New Zealand pattern of

\footnotetext{
144 Tennant, The Fabric of Welfare, p.31.

145 Ibid, pp.30-31; Thomson, A World Without Welfare, p.24.

146 Thomson, $A$ World Without Welfare, p.161.

147 Tennant, The Fabric of Welfare, p.36.

148 Ibid, pp.36-37.
} 
a "mixed economy of welfare", where both government and private charity worked together, as argued by Margaret Tennant. ${ }^{149}$ Women were often heavily involved in charitable and benevolent societies in New Zealand throughout the 1880s to 1920s as such activity was one of the few avenues of public activity open to respectable middle- and upper-class women at this time. Tennant noted that for women, charity work "provided an acceptable bridge between home and the public sphere."150

If the welfare situation in New Zealand in the late Victorian and Edwardian eras created a space for women's activity in charitable work, developments at the start of the twentieth century also provided an opportunity for greater engagement in the imperial mission. Julia Bush, in Edwardian Ladies and Imperial Power, considered that in the early twentieth century, as the imperial project turned from one of conquest to one of building a sustainable and civilising Empire, the importance of female virtues in this mission came to the fore. ${ }^{151}$ This shift in thinking about the Empire allowed for the development of female imperialism, described by Katie Pickles as "the gendered work of elite women to promote British imperialism". ${ }^{152}$ Women's imperialist activity formed a significant part of British imperialism, itself a popular movement seeking to cultivate British culture across the Empire. ${ }^{153}$ For women involved in imperialist organisations, their mission was to expand on men's work for Empire by undertaking their own, women-specific and practical work which fit neatly beside that of men. Women's imperialist organisations sought to create networks of women across the Empire, all working towards the improvement and stability of the Empire.

As part of claiming a greater part in the imperial project, women established imperialist organisations which sought to undertake practical work in both Britain and the various colonies, and which would complement rather than diminish men's own imperial endeavours. Bush described some of the central activities of female imperialists as "guiding emigration, offering moral protection to women settlers, supporting church-building and missionary work abroad, and providing juvenile

\footnotetext{
149 Ibid, pp.9, 36-37, 40-41.

150 Ibid, p.22.

151 Bush, p.2.

152 Katie Pickles, 'A Link in "The great Chain of Empire Friendship": The Victoria League in New Zealand', The Journal of Imperial and Commonwealth History, Vol. 33, no. 1, January 2005, p.29. 153 On the need to expand British culture across the Empire see John Robert Seeley, The Expansion of England: Two Courses of Lectures (London: Macmillan and Co., 1883).
} 
imperialist education and hospitality for colonial visitors at home."154 The associations established by female imperialists were often Empire-wide, with branches of each organisation established and run by leading women in both Britain and the colonies. Organisations such as the Victoria League (established in Britain in 1901), the Primrose League (Britain, 1885), the Imperial Order Daughters of the Empire (Canada, 1900), and the Girls' Friendly Society (Britain, 1875) counted among the imperial organisations established by elite women of the late Victorian and Edwardian periods. The women who initiated and those who became active members of imperial organisations generally came from the upper levels of the British or colonial elite. Governor's wives were counted among those women who joined female imperial organisations. Bush noted that Lady Talbot, wife of the Governor of Victoria from 1904, was an executive member of the leading emigration societies as well as being a Victoria League Council member.155

Across the Empire, governors' wives' in the late Victorian and Edwardian periods were active in voluntary welfare and female imperialist organisations. Lady Ishbel Aberdeen, who spent time in both Canada (from 1893 to 1898) and Ireland (from 1906 to 1915) as a vice-regal wife was heavily involved in philanthropic and imperial endeavours during her husband's terms in office. Lady Aberdeen devoted herself to improving the health and welfare of those settlers living in the two colonies. ${ }^{156}$ She also sought to cultivate a national identity among the widely dispersed (and diverse in origins) settler population of Canada, while still maintaining links to Britain and the Empire. ${ }^{157}$ Her ambitions for Ireland were similar. ${ }^{158}$ Lady Aberdeen was active in local welfare work and promoting Britain and the Empire in her pursuit of these goals. In Canada, she established and presided over several women's organisations, including the National Council of Women of Canada, which organised local philanthropic work, and the Victorian Order of Nurses, a countrywide visiting nursing service. ${ }^{159}$ In Ireland, Lady Aberdeen engaged in similar endeavours to those of Canada, setting up the Women's National Health Association of Ireland, which sought to fight tuberculosis and instil personal

\footnotetext{
154 Bush, p.3.

155 Ibid, p.39.

156 McLeish, p.267.

157 Ibid, pp.271-272.

158 Ibid, p.273.

159 Ibid, pp.271-272.
} 
responsibility for health among the Irish, as well as providing advice on raising healthy children. ${ }^{160}$

Another vice-regal wife who was heavily involved in philanthropy and imperial endeavours was Lady Hariot Dufferin (mother of one of New Zealand's vice-regal wives, Victoria Plunket) who spent time in both Canada (from 1872 to 1878) and India (from 1884 to 1888) as a governor's wife. The most famous among the initiatives she created was the National Association for Supplying Medical Aid to the Women of India, commonly referred to as the Dufferin Fund. ${ }^{161}$ The Fund was established to tackle the issue of the provision of medical aid to Indian women of higher classes who observed Purdah, a system whereby women were not permitted to see any men other than close relatives, and so were considerably constrained when seeking medical aid. ${ }^{162}$ The Fund sought to use female British doctors to train Indian women in modern medical methods so that they could practice among Indian women, and the goal was for the Fund to become self-supporting, with trained Indian women continuing to train others. ${ }^{163}$

Both Lady Aberdeen and Lady Dufferin's actions while governors' wives can be understood as forming part of the growing involvement of vice-regal ladies in the areas of voluntary welfare and women's imperial activity in the late Victorian and Edwardian eras. Their actions were among the more exceptional of those undertaken by vice-regal wives in this period in that they were the driving force behind initiatives which not only largely benefitted women in need, but which also empowered women to take meaningful action and contributed to a greater mobilisation of women acting in the interests of women. Activity on the level of Lady Aberdeen and Lady Dufferin is evident on occasion in the New Zealand context, in organisations such as the Royal New Zealand Plunket Society (itself under the patronage of Lady Dufferin's daughter, Victoria) and the Lady Liverpool Fund.

\footnotetext{
160 Ibid, pp.273-274.

161 Andrews, pp.189-190.

162 Ibid, pp.188-189.

163 Ibid, pp.189-190; Richard Davenport-Hines, 'Blackwood, Hariot Georgina Hamilton-Temple-, marchioness of Dufferin and Ava (1843-1936)', Oxford Dictionary of National Biography, updated January 2008; doi:10.1093/ref:odnb/56107; accessed 29 May 2015.
} 
Among the many institutions with which New Zealand governors' wives were involved was the Girls' Friendly Society (GFS). The first New Zealand branch of the GFS was founded in Christchurch in 1882 after promotion by Alice J. E. Lane, a former branch leader of the GFS in England. ${ }^{164}$ The leadership of the Christchurch branch was comprised of wives of prominent churchmen, lawyers, and businessmen, and its patrons were Archbishop Harper and Reverend Dean Jacobs. ${ }^{165}$ The GFS had originally been founded at Winchester in England in 1875 by wives of senior clergy and members of the local gentry who "shared a common view on upper- and middle-class women's responsibility for protecting working-class girls."166 At first, the GFS had very little relationship to the imperial project, but by the 1880s the society was taking on an ever greater part in imperialism, in particular with regard to emigration programmes that the GFS endorsed.167 After the establishment of the first New Zealand GFS branch, the society developed further with the arrival of Lady Jervois to the colony at the start of 1883. Lady Jervois was the wife of New Zealand's new Governor Sir William Jervois. Prior to taking up office in New Zealand, Sir William and Lady Jervois had been in South Australia where Sir William was governor and where Lady Jervois had already founded a branch of the GFS in Adelaide. ${ }^{168}$

Lady Jervois continued her involvement with the GFS while in New Zealand, with branches in Auckland and Wellington founded not long after her arrival in the colony, most likely in 1883. The exact date of the establishment of these two branches is unknown. A short history of the GFS in New Zealand does not give the year of the establishment of the Auckland and Wellington branches, stating only that the Auckland branch was formed on May 5 at Government House Auckland on Lady Jervois' first visit to the city, while the Wellington branch was formed on July 10.169 There were no newspaper reports on the formation of the Auckland branch on or around May 1883, but reports do show that the branch was running by January

\footnotetext{
164 Fiona McKergow, 'Girls' Friendly Society 1882 -', in Anne Else (ed.), Women Together: A History of Women's Organisations in New Zealand Ngā Rōpü Wāhine o te Motu (Wellington: Daphne Brasell Associates Press and Historical Branch, Department of Internal Affairs, 1993), p.129. 165 Mollie D. Gambrill, The Girls' Friendly Society in New Zealand, 1882-1983 [Wellington: The Society, 1983], p.3.

166 Bush, p.41.

167 Ibid, pp.41-42.

168 Gambrill, p.3.

169 Ibid, pp.3-4.
} 
1884. ${ }^{170}$ As for the Wellington branch, a small article in the Evening Post on 11 July 1883 noted that on 10 July a group of ladies met at Government House to consider the formation of a GFS branch. ${ }^{171}$ That two GFS branches were formed in New Zealand's main centres within the first six months of Lady Jervois' arrival in the colony indicates the priority and interest that the new governor's wife took in the society, an interest that was borne out by her actions on its behalf.

An active and involved patron, Lady Jervois contributed much of her time and effort while in New Zealand to the success of the GFS. She was both patroness and president of the Wellington branch, and regular meetings of the society were held at Government House to discuss its direction and work. Among the duties that Lady Jervois undertook to further the aims of the GFS were giving addresses and reading papers at meetings on the subject of women's work in the world, handing out prizes for needlework and for Bible questions, or presenting 'cards of merit' to GFS members who had remained in the same employment for a minimum of three years. ${ }^{172}$ She was particularly concerned with promoting and explaining the work of the GFS which in her own words was not "a society for petting and spoiling young women, but a society for bracing and strengthening them for the worthier performance of the duties of life, and so for making them better women."173 She often spoke of the many opportunities it afforded all women, not only for those who needed the help of the society but also for those who were in a position to carry out and contribute to the work of the society. ${ }^{174}$ In her addresses, she often mentioned the relationship the GFS had with God, comparing the GFS to an army of God, and noting that it was an open society "which all women leading pure lives may join, be they young or old, rich or poor."175 As president and patroness of the Wellington branch of the GFS, Lady Jervois took on the responsibility of providing the society with a direction to follow and of communicating the values and goals of the society to the public. This last duty was an important one, and Lady Jervois' status as a

\footnotetext{
170 'St. Paul's Episcopal Church', NZH, 22 January 1884, p.6.

171 EP, 11 July 1883, p.2, column 5.

172 'The Girls' Friendly Society', EP, 22 September 1888, p.2; 'Telegrams', EP, 10 May 1884, p.2, column 8; $E P, 9$ July 1887, p.2, column 5.

173 'The Girls' Friendly Society', EP, 22 September 1888, p.2

174 Ibid; 'Girls' Friendly Society', EP, 17 August 1885, p.4.

175 'Girls' Friendly Society', EP, 17 August 1885, p.4.
} 
governor's wife gave the society an immediate public profile, which was a driver for the GFS's overall viability as an organisation, especially in its initial years.

Through her position as a vice-regal wife, and the profile this afforded the GFS, Lady Jervois was also a leading factor in the success or otherwise of fund raising for the society. Certainly, lady members often raised funds on their own and many did manage to reach substantial figures by collecting subscriptions. At one GFS meeting in 1885 Lady Jervois congratulated two members who together had raised between $£ 9$ and $£ 10$ in subscriptions, while two others collected between $£ 4$ and $£ 5.176$ These day to day activities were a vital part of ensuring the GFS continued in its work, but the participation of the governor's wife in one-off fund raising events such as charitable bazaars or cake stalls could contribute even more by ensuring a public profile for the organisation or perhaps greater attendance (and consequently greater takings) at the fund raising event. In his work on female philanthropy in England, Frank Prochaska noted that "[a] stall presided over by the Queen gave the greatest mark of distinction and guaranteed a large turn-out of nobility and gentry, and a tidy profit. ... Failing the Queen any distinguished lady, preferably with a title, ensured an increase in sales."177 Lady Jervois, as the wife of the monarch's representative, was as close as one could get to royalty in the colony.

In August 1885, the GFS rented a six-roomed house in central Wellington as accommodation for any women members who had no other home to go to. ${ }^{178}$ The GFS paid the wages of a matron to oversee the running of the building which was a large and ongoing financial cost. ${ }^{179}$ As the GFS grew, a need soon arose for something more permanent under GFS ownership. ${ }^{180}$ Over the next three years, the GFS worked towards raising enough money to buy or build a permanent GFS Lodge by putting on various events, among them a Doll Show (an exhibition of handmade dolls in various forms of dress) and a Cake and Fancy Fair. ${ }^{181}$ Lady Jervois played a prominent part in these two events. At the Doll Show in November 1886 she

\footnotetext{
176 Ibid.

177 F. K. Prochaska, Women and Philanthropy in Nineteenth-Century England (New York: Oxford University Press, 1980), p.65.

178 Gambrill, p.4; 'Girls' Friendly Society', EP, 17 August 1885, p.4.

179 Gambrill, p.4.

180 Ibid; 'Girls' Friendly Society', EP, 17 August 1885, p.4.

181 Gambrill, p.4; 'The Doll Show', EP, 3 November 1886, p.3; 'Girls' Friendly Society', EP, 17 August 1885, p.4; 'The Cake and Fancy Fair', EP, 6 December 1888, p.2.
} 
formally opened the event and also contributed her own dressed dolls depicting a model of Queen Victoria holding a drawing-room, which were in the words of the Evening Post, "the best part of the exhibition", the dresses being "simply superb, and ... in every detail correct and in good taste." 182 The first day of the show raised almost $£ 70$, with a total of close to $£ 250$ collected at the close of the show, three days later. ${ }^{183}$ A couple of months after the Doll Show, in January 1887, the GFS were able to open a new building on Vivian Street in Wellington. ${ }^{184}$

A substantial debt on the building remained, however, and it was only through the success of the Cake and Fancy Fair, initiated by Lady Jervois and held in December 1888, that the debt was finally reduced to a manageable $£ 33 .{ }^{185}$ The total made at the Fair was a "larger than anticipated" $£ 439$, which once expenses were accounted for, left the GFS with $£ 322$ to help discharge the debt owed on the GFS premises. ${ }^{186}$ The Fair had been opened by the Governor who was accompanied by Lady Jervois and an ADC. In his opening address, Sir William urged those present to spend as much as they could: "Ladies and gentlement [sic], we want so much money; provide it; go and buy things at this Fair, which will produce the sum of $£ 400$ at least, and I hope $£ 1,000$." 187 The items on offer at the Fair were certainly fantastic enough to induce those present to part with their money. A four-tier wedding cake made by the Government House cook, Mrs. Turley, took pride of place at one stall, while the centre of another table featured a large peacock, "ready for cooking" and "for sale at a reasonable figure". The ladies in charge of the peacock hoped to also sell its feathers by way of a raffle. ${ }^{188}$

The presence of the Governor and Lady Jervois at the Fair almost certainly contributed to its overall success and the large sum raised. As already noted, a link with royalty or the aristocracy could be beneficial to the number of people who attended a fund raising event, and therefore to the total sum achieved. This was borne out in New Zealand in 1901 during the Royal tour of the Duke and Duchess of York. They attended a charitable bazaar in aid of the Home for Incurables, and the

\footnotetext{
182 'The Doll Show', EP, 3 November 1886, p.3.

${ }^{183} E P$, 4 November 1886, p.2, column 3; EP, 8 November 1886, p.2, column 4.

184 'The Girls' Friendly Society's New Lodge', EP, 6 January 1887, p.4.

${ }^{185} \mathrm{EP}, 5$ January 1889, p.3. column 2.

186 Ibid.

187 'The Cake and Fancy Fair', EP, 6 December 1888, p.2.

188 Ibid.
} 
New Zealand Herald implied that due to the royals' visit, "[t]he bazaar's success artistically is established, and there is little doubt of its success financially."189 Similarly the governor and his wife in their vice-regal capacity lent a charitable event their status, respectability, and profile. The involvement and visible hard work of a governor's wife in a charitable or imperialist organisation not only attracted people to the cause but also imbued it with a certain credibility and authority. The participation or association of governors' wives with an organisation was, therefore, highly sought-after.

In the case of Lady Jervois, she was not only involved in the GFS as its president and patroness and through her fund raising efforts on its behalf, but her attachment to the cause was widely known and reported by the press. In one instance after the success of the Cake and Fancy Fair, the Evening Post noted that Lady Jervois "[had] always taken a warm interest in the affairs of the society", while 'Clio', the editor of the Post's 'Ladies' Column', opined that she had been "a backbone of strength to the society" and feared how the society would fare without her at its helm when she departed the colony. ${ }^{190}$ Through their devotion to a cause, governors' wives could have a lasting impact upon the achievements of an organisation. This was so with the GFS. It continued to provide accommodation and help find employment for immigrant women throughout the country until the $1920 \mathrm{~s}$ when immigration largely stopped. ${ }^{191}$ It also kept up its welfare work, which became especially important during the years of the Great Depression, although this became less important from 1938 with the advent of social security in New Zealand. ${ }^{192}$ World War Two had the biggest detrimental effect on the GFS, and most of the branches around the country had wound up by the late 1950s. Only the Wellington branch continued to endure - it maintained its hostel programme throughout the twentieth century (although the location changed over the years), and continued to provide aid to women in need into the 1990s. ${ }^{193}$

The part played by Lady Plunket in the Society for Promoting the Health of Women and Children (or the Royal New Zealand Plunket Society (RNZPS), as it later

\footnotetext{
189 'Other Functions', NZH, 19 June 1901, p.5.

190 EP, 5 January 1889, p.3, column 2; 'The Ladies' Column', EP, 6 October 1888, p.1.

191 McKergow, pp.130-131.

192 Ibid, p.131.

193 Ibid.
} 
became known) was similar to the involvement of Lady Jervois in the GFS in that Lady Plunket gave more than her name to the organisation. The RNZPS, however, differed in that it was a new organisation created in response to a perceived crisis of the early twentieth century. In addition, it was also created as a society for all women and babies, not just those who were poor or 'in need'. The RNZPS was formed in 1907 with a view to improving the survival and health of infants, and to advise and guide mothers in best practice for raising children. In particular, the RNZPS focussed on modern science as a tool for raising healthy children and emphasised the importance of breast feeding, or at least using the correct infant formula, to the overall health and wellbeing of infants. ${ }^{194}$ It also provided advice and education on raising children. ${ }^{195}$ Since its inception it has become one of the most celebrated of New Zealand's voluntary institutions and is remarkable for retaining its independence from the state in the running of its affairs over many decades while also receiving generous financial contributions from the government during that time. ${ }^{196}$

The man behind the Society was Dr Frederic Truby King who, although not a trained paediatrician, nonetheless developed an intense interest in infant welfare during his working life. Linda Bryder described him as "an intellectual and a fanatical enthusiast: once he had decided to make infant health his chosen area he read avidly and travelled widely, rubbing shoulders with world authorities in the new and growing profession of paediatrics." 197 King's interest in infant and maternal health did not grow solely out of a concern for promoting the health and wellbeing of individual mothers and children. Rather, he believed that women's true and only role in society was to be mothers, and he considered that in the early years of the twentieth century women were failing in that central mission. ${ }^{198}$ He argued against higher education and employment in professions for women as he considered that both deflected women's energies away from their natural function, motherhood. ${ }^{199}$ Only by educating women in domesticity and child-rearing would children be

\footnotetext{
194 Oppenheimer, “'Hidden under many bushels"', p.27.

195 Ibid.

196 Bryder, p.ix.

197 Ibid, p.8.

198 Erik Olssen, 'Truby King and the Plunket Society: An Analysis of a Prescriptive Ideology', New Zealand Journal of History, Vol. 15, no. 1, 1981, pp.6-7.

199 Ibid.
} 
healthy and productive contributors to the nation, thus avoiding racial degeneracy. ${ }^{200}$ Consequently he advocated for a scientific approach to motherhood and infant health.

King's movement began in an era in which there was growing anxiety about the quality of the British race. At the start of the twentieth century, the general health and fitness of the imperial population was of increasing concern across the British Empire. 201 The Anglo-South African War had exposed the apparent problem of the quality of the population, when up to a third of recruits were found to be unfit for military duty due to physical deficiencies. ${ }^{202}$ In New Zealand, infant health was a political as well as imperial concern. In response to a perceived (and actual) fall in the Pākehā birth rate and the stagnant infant mortality rate, the government became involved, setting up committees and debating bills on infant and maternal health. ${ }^{203}$ The Premier, Richard Seddon, declared that "babies are our best immigrants", and in particular that these babies should be the product of the white settler population. ${ }^{204}$ Numerous healthy children equalled a strong and prosperous nation, and would contribute to a strong and prosperous Empire, a necessity considering the military and economic strength of rival powers Germany, Japan and the United States. ${ }^{205}$ The health of women as mothers - the producers of the next generation of the imperial population - thus came to be of major concern. ${ }^{206}$

This anxious environment facilitated the creation of King's Society for Promoting the Health of Women and Children. In order for the society to gain widespread support, he needed a patron. Lady Victoria Plunket heard about King's idea for a society on 21 October 1907 at a Wellington Town Hall meeting, and a

\footnotetext{
200 Ibid, p.6.

${ }^{201}$ It was also a concern across many European nations - in particular France - which worried not only about a declining birth rate but also the 'quality' of the population who were born. On this matter, see Alice L. Conklin, 'Redefining "Frenchness": Citizenship, Race Regeneration, and Imperial Motherhood in France and West Africa, 1914-40', in Julia Clancy-Smith and Frances Gouda (eds.), Domesticating the Empire: Race, Gender, and Family Life in French and Dutch Colonialism (Charlottesville and London: University Press of Virginia, 1998), pp.68, 71-72; and Elisa Camiscioli, 'Producing Citizens, Reproducing the "French Race": Immigration, Demography, and Pronatalism in Early Twentieth-Century France', Gender \& History, Vol. 13, no. 3, November 2001, pp.593-621.

202 Bryder, p.1.

203 Ibid, pp.1-2.

${ }^{204}$ As quoted in Bryder, p.1.

205 Bryder, p.2.

${ }^{206}$ Bryder discusses the early twentieth century concerns of politicians and health officials over the country's birth rate, infant death rate and potential strategies to improve the situation in her book. See, Bryder, pp.1-8.
} 
month later agreed to become patroness of the Dunedin Society. ${ }^{207}$ Lady Plunket soon became deeply involved in the work of the RNZPS. As well as helping to set up branches of the RNZPS around the Dominion, Lady Plunket actively engaged in the day to day running of affairs, giving public lectures and demonstrations on how to make humanised milk. ${ }^{208}$ Newspapers at the time commented on the extent to which Lady Plunket threw herself into her work, noting that she was "a most ardent and enthusiastic worker" who took "such keen interest and an active part" in the society. ${ }^{209}$ But perhaps her most important work for the RNZPS was her idea to create a professionalised nursing guild to carry out the work of the society across the Dominion, with the Karitane Home in Dunedin (the first of several Plunket Hospitals where new and expectant mothers could stay with their babies who were failing to thrive) serving as a training centre for what became known as Plunket Nurses. ${ }^{210}$ This initiative distinguished the RNZPS from other infant welfare societies which, while developing and researching different methods and strategies for managing infant health, did not look to provide an organised system of nursing to carry out their work. ${ }^{211}$

Lady Plunket and her husband arrived in New Zealand in 1904, three years prior to the establishment of the RNZPS. During these years, Lady Plunket had searched for an organisation that she could get involved with. ${ }^{212}$ The RNZPS, with its focus on the health of mothers and children, provided the perfect fit for the thirtyfour year old mother of seven (soon to be eight) young children. ${ }^{213}$ Lady Plunket's identity as a mother and wife naturally lent itself to the aims of the RNZPS. Although she was not the only governors' wife to be a mother, that she was a young mother who believed in King's teachings, and that she had a large number of young children at a time when the birth rate was in decline, spoke to her suitability as a patron. She

\footnotetext{
207 'Saving the Race', EP, 22 October 1907, p.2; Bryder, p.18.

208 Bryder, pp.18-19; Oppenheimer, '“Hidden under many bushels"', pp.30-31.

209 'Protection of Women and Children', ODT, 17 March 1906, p.5; 'Lady Plunket's Visit', ODT, 9 August 1909, p.2 'Lady Plunket's Departure', EP, 10 February 1910, p.8.

210 Oppenheimer, “'Hidden under many bushels"', p.30.

211 Ibid, p.25.

212 Ibid, pp.27-28.

213 When the Plunkets arrived in New Zealand in 1904, they already had six children. In March 1907, while on a visit home, Lady Plunket gave birth to a daughter and in 1909 while in New Zealand, the Plunkets welcomed a son. 'The Governor's Family', NZH, 2 April 1907, p.5; 'Lady Plunket. Birth of Another Son', NZH, 8 February 1909, p.5; see also, Oppenheimer, "'Hidden under many bushels"', p.23.
} 
herself was a living example of best practice in child rearing. Her vice-regal identity also contributed to her success as a patron. As an imperial figure she lent the RNZPS her authority and credibility, and helped to popularise King's methods. That she was a woman too, one vested with imperial power, would also have helped sanction the male King's new scientific and modern methods among New Zealand society. By lending her name and time to the society, King's novel methods could be equated with a respectable upper class vice-regal wife and mother.

A third New Zealand governor's wife who left her mark through an organisation bearing her name was Lady Liverpool. She and her husband Lord Liverpool held vice-regal office from 1912 to 1920. Lady Liverpool was instrumental in encouraging New Zealand women's patriotic efforts during World War One. Two days after Britain declared war on Germany in August 1914, Lady Liverpool wrote a letter of appeal to the women of New Zealand which was published in many newspapers. In her appeal, Lady Liverpool asked New Zealand's women "to assist me in trying to provide any necessaries which may be required for those portions of the citizen army which are now mobilising for any service that may be required of them." 214 She suggested that women start local funds under a small committee, perhaps headed by the local mayoress, which could receive contributions to the war effort. ${ }^{215}$ These items were then collected and made into parcels for the soldiers at the front under the organisation of the Lady Liverpool Fund (LLF). The parcels were composed of items made or donated by New Zealand women, these often being socks, balaclavas, mittens, underclothing, cigarettes, cakes and other items to give the soldiers some comforts and a taste of home. ${ }^{216}$ From the beginning, Lady Liverpool led New Zealand women's contributions to the war effort.

In addition to organising the Fund, together with Mīria Woodbine Pōmare, wife of Dr Māui Pōmare (Member of Parliament for Western Māori), Lady Liverpool formed the Lady Liverpool's and Mrs Pōmare's Māori Soldiers' Fund in 1915 in support of the Māori Pioneer Contingent, with Lady Liverpool acting as president. ${ }^{217}$

\footnotetext{
214 'Appeal to Women', NZH, 7 August 1914, p.9.

215 Ibid.

216 'Expeditionary Force Organised', Press, 10 August 1914, p.9; 'Additional Gifts', EP, 15 January 1915, p.2.

217 Tania Rei, 'Lady Liverpool's and Mrs Pōmare's Māori Soldiers' Fund, 1915-1921', in Anne Else (ed.), Women Together: A History of Women's Organisations in New Zealand Ngā Rōpū Wāhine o te
} 
The Fund worked to send Māori soldiers parcels containing "letters, knitted garments, personalised tāniko, and foods such as strings of dried pipi and preserved mutton birds."218 In August 1915 Lady Liverpool contributed further to the war effort when she published Her Excellency's Knitting Book, a compilation of knitting patterns for items needed at the front. Proceeds from the sale of the book were donated to the St John Ambulance base hospital. ${ }^{219}$ Lady Liverpool's efforts were not limited to organising at the higher end of war time contributions. She also contributed to practical work by knitting items for soldiers herself and packing parcels of comforts to send to the front. On 25 June 1918 she wrote to Captain Seddon, Richard Seddon's son and himself a Member of Parliament, informing him that she had spent her morning knitting at the Red Cross depot and that later that week she would help to sell socks at the Red Cross stall in Queen Street in Auckland. ${ }^{220}$ A fortnight earlier she had helped pack parcels in the Auckland Town Hall and, privately, she thought that the Auckland parcels "are not nearly as good as the Christchurch ones". 221

As well as working to organise care parcels for soldiers, Lady Liverpool on various occasions also handed out medals in honour of New Zealand's mothers and wives. At an afternoon tea given by the Women's National Reserve for soldiers' and sailors' mothers in Dunedin in March 1918, Lady Liverpool presented all those mothers who desired them silver badges which would, in her words, "serve as a link of sympathy and a bond of union among the mothers who wore them." 222 At another meeting of the Women's National Reserve in Christchurch several days earlier, Lady Liverpool again handed out badges to mothers and wives of soldiers. ${ }^{223}$ The badges for mothers were silver and circular, with two fern leaves engraved on them, a shield with the letters 'N.Z.', a crown, and the words 'Mothers of Empire', while those badges for soldiers' wives were in the form of a ring with a crown and the words,

\footnotetext{
Motu (Wellington: Daphne Brasell Associates Press and Historical Branch, Department of Internal Affairs, 1993), p.23.

218 Ibid, p.24.

219 '“Her Excellency's Knitting Book"', ODT, 21 August 1915, p.12.

${ }^{220}$ Annette Liverpool to Captain Seddon, 25 June 1918, Letters from Governors-General and aides, 1901-1954, MS-Papers-1619-146, ATL, Wellington. Captain Seddon's political career perhaps explains why Lady Liverpool was writing to him during the war.

221 Ibid.

222 'Mothers of Heroes', ODT, 25 March 1918, p.2

223 'Women's National Reserve', Press, 21 March 1918, p.2.
} 
'Wives of New Zealand'. ${ }^{224}$ The badges provided a visible link between women's war efforts as a type of military service through the sacrifice of husbands and sons to the trenches.

The years of World War One were a time of intense patriotism and loyalty in New Zealand when the virtues of service and duty were highly valued. Lady Liverpool's patriotic actions in contribution to the war effort were borne out of, and a response to, the crisis of war. Her Fund and other initiatives provided a means by which New Zealand women could contribute in a practical, meaningful way to war efforts. In giving her name to the Fund, Lady Liverpool imbued it with her vice-regal authority. Her call to action was made as a woman, and she issued her call to the women of New Zealand to do their part in a time of national and imperial need. By giving their time, skills, goods, and money to the cause Lady Liverpool and the women of the Dominion contributed to the war effort in a gender-specific manner, and further emphasised the notion of women as mothers of Empire, either literally or through their motherly war time efforts.

The three organisations discussed so far - the Girls' Friendly Society, the Plunket Society, and the Lady Liverpool Fund - were exceptional cases of governors' wives' involvement in voluntary organisations in New Zealand. The last two in particular can be understood as large scale responses to crises or issues (real and perceived) of their time. Other organisations with which governors' wives were involved were representative of more general ideas and movements of their time. The Mothers' Union was an organisation which aimed to help women in the 'training' and upbringing of their children. Unions had already been established in Britain, and the first meeting to consider a New Zealand Union was called in 1886 by Alice Augusta Pascoe, a vicar's wife from Christchurch. ${ }^{225}$ In February 1889, Lady Jervois proposed establishing a Mothers' Union in Wellington but when she and her husband left the colony a month later she lost the opportunity to pursue the idea further. ${ }^{226}$ The proposal was eventually taken up by Lady Glasgow in January 1893, about six months into Lord Glasgow's term in office. Over one hundred ladies

\footnotetext{
224 Ibid.

225 Elizabeth Hay, 'Association of Anglican Women 1886-', in Anne Else (ed.), Women Together: A History of Women's Organisations in New Zealand Ngã Rōpü Wāhine o te Motu (Wellington: Daphne Brasell Associates Press and Historical Branch, Department of Internal Affairs, 1993), p.165. ${ }^{226} E P, 2$ February 1889, p.2, column 5.
} 
attended a meeting in Wellington in which Lady Glasgow proposed setting up a Mothers' Union along the lines of similar groups in Scotland.227 The Union was intended to be nondenominational, following the model of the Scottish Union, although in practice it appears to have been closely aligned with the Anglican Church. ${ }^{228}$

The Union benefitted from Lady Glasgow's involvement from the start. Much as Lady Jervois had been instrumental in establishing the GFS, Lady Glasgow was active in spreading the organisation throughout New Zealand. As Elizabeth Hay noted in her short history of the organisation, the Union "became firmly established here through the work of the Countess of Glasgow". ${ }^{229}$ She sought to establish branches of the Union all over New Zealand, calling meetings of women in Christchurch, Lyttelton, Auckland, and Napier in 1893. ${ }^{230}$ She also headed a general committee (which would meet twice a year) composed of one woman from each church in the town. ${ }^{231}$ Later governors' wives continued the vice-regal association with the Mothers' Union. Lady Ranfurly was president of the Union during her years in New Zealand and attended meetings and hosted events at Government House for members. ${ }^{232}$ Lady Plunket was also the president and engaged in similar activities to Lady Ranfurly, attending a Mothers' Union garden party in January 1905.233 Both Lady Islington and Lady Jellicoe similarly kept up the vice-regal links with the Union, each attending the annual social of the St. Matthew's Mothers' Union in 1911 and 1922 respectively. ${ }^{234}$

The Mothers' Union can be understood as forming part of ideas popular at the time about women as mothers of the Empire, continued in later years by the Plunket Society and women's wartime contributions. The Union aimed to help women raise respectful and responsible children who would grow up to be productive and dutiful citizens. It also idolised motherhood. At a meeting of the Union in May 1911 Lady

\footnotetext{
227 'A Mothers' Union', NZH, 10 January 1893, p.5.

228 'Meeting at Lyttelton', Press, 20 January 1893, p.6; Hay, pp.165-167.

229 Hay, p.165.

230 'The Mothers' Union', NZH, 20 January 1893, p.5; 'New Zealand Mothers' Union', NZH, 12 April

1893, p.6; 'The Governor and Lady Glasgow at Napier', NZH, 23 March 1893, p.5.

231 'New Zealand Mothers' Union', NZH, 12 April 1893, p.6

232 'Welcome to Lady Ranfurly', ODT, 7 June 1901, p.5; 'Garden Party at Government House', NZH, 21

April 1900, p.5.

233 'The Governor', NZH, 6 January 1905, p.5.

234 'The Mother', ODT, 27 May 1911, p.5; 'Mothers' Union Social', NZH, 2 June 1922, p.9.
} 
Islington gave an address about motherhood and called mothers "the holiest thing alive."235 The cult of motherhood promoted by the Mothers' Union was linked to the idea of women's imperial mission to civilise the Empire through their actions. The message of the Union was a conservative one in line with other women's imperialist organisations of the time which positioned women as carrying out women-centric work for the good of the Empire. That the organisation spread throughout the colony in 1893, the year New Zealand women won the right to vote also throws its conservative nature into sharper relief.

The continuity in vice-regal patronage noted above was not restricted to the Mothers' Union. Indeed it was quite common for governors' wives to pick up the work or position occupied by the previous wife in an organisation. The GFS, even after Lady Jervois left the colony, continued its activities and maintained its links with Government House well into the twentieth century. In 1909 Lady Plunket attended an opening of a GFS lodge and, in 1911, Lady Islington gave an "eloquent" speech in appeal for funds to help the GFS erect a new building in Auckland. ${ }^{236}$ In some cases, continuity of vice-regal patronage and attention came about due to the actions of the vice-regal ladies themselves. At the annual meeting of the RNZPS in 1911, Lady Islington gave a brief address where she commented not only on the work of the Society, but also noted that before she left Britain, Lady Plunket had urged her to advance the interests of the Society. ${ }^{237}$ The imperial circles that these women moved in provided them with an opportunity to press for the continuation of the organisations they started through those that followed them. Indeed this trend has endured. Vice-regal patronage of the RNZPS continues with New Zealand's current Governor-General, Sir Jerry Mateparae, acting as its patron while his wife, Lady Janine Mateparae, acts as patroness of GirlGuiding New Zealand, an organisation begun in the early twentieth century. ${ }^{238}$

\footnotetext{
235 'The Mother', ODT, 27 May 1911, p.5

236 'The Governor', NZH, 2 September 1909, p.5; 'Befriending the Girls', ODT, 1 June 1911, p.7.

237 'Care of the Babies', ODT, 3 May 1911, p.8.

238 'Vice-Regal Patronage', http://gg.govt.nz/the-governor-general/patronage; accessed 3 February

2015. Girl Guides first organised as a group in New Zealand in 1908 when they were called Girl Peace Scouts: Judith Bright, 'Girl Guides Association New Zealand 1908-', in Anne Else (ed.), Women Together: A History of Women's Organisations in New Zealand Ngā Rōpū Wāhine o te Motu (Wellington: Daphne Brasell Associates Press and Historical Branch, Department of Internal Affairs, 1993), p.422.
} 
Links with empire were often emphasised by governors' wives when giving public addresses for the organisations they were involved with. Lady Islington, in an address to the Girls' Peace Scouts, spoke of the girls' patriotism for New Zealand and encouraged them to think fondly and affectionately of the Mother Country. ${ }^{239}$ In 1900, Lord and Lady Ranfurly held a garden party at Government House for members of the Auckland Mothers' Union. At this event, the Governor spoke of the "bright example of motherhood" provided by Queen Victoria and also commented disapprovingly on the lack of reverence and obedience in colonial children. ${ }^{240}$ Comparing New Zealanders to those in Britain was a common action by governors and their wives. Lady Islington and Lady Plunket often referred to women and young girls back 'Home' in comparison with colonial girls, thus emphasising the link between New Zealand and Britain and also using it as an opportunity to emphasise the superiority of British manners and child rearing techniques. ${ }^{241}$ Such comments served to demonstrate the hierarchy of Empire, with New Zealand ranked below Britain, and also imbued the vice-regal couple with authority over matters pertaining to women and children.

Vice-regal involvement in organisations was not restricted to those such as the GFS and Plunket Society which endured over many years. They could also step in and provide aid for singular causes and crises. On 26 March 1896, the Brunner Mine near Greymouth was the site of an explosion which resulted in the deaths of 65 men. ${ }^{242}$ The Brunnerton Relief Fund was established to provide aid to the families of the deceased. Their Excellencies the Earl and Countess of Glasgow contributed to fund raising efforts by being patrons (along with the Auckland mayors) of an athletic carnival in Auckland. ${ }^{243}$ The Ranfurlys were also involved in establishing a Veteran's Home for all those who had served in the Imperial Army or Navy or those who had served and received medals in the Anglo-South African War or the New Zealand wars. The initiative came mostly from the Governor, but Lady Ranfurly worked as president of a ladies' committee which helped to organise fund raising efforts for the

\footnotetext{
239 'Girl Peace Scouts', NZH, 30 November 1912, p.5.

240 'Garden Party at Government House', NZH, 21 April 1900, p.5.

241 'Duties of Motherhood', NZH, 28 March 1912, p.4; 'Lady Plunket Interviewed', NZH, 31 August 1904, p.2

242 'Shocking Mining Disaster', EP, 26 March 1896, p.3; 'The Brunnerton Relief Fund', ODT, 9 April 1896, p.2.

243 'The Brunnerton Relief Fund', NZH, 13 April 1896, p.5.
} 
Home. ${ }^{244}$ The Home, located in Auckland and which served also as a memorial to those who died in the Anglo-South African War, was opened by the Governor on 10 December 1903.245

Governors' wives often paid visits to other institutions such as orphanages, rest homes, hospitals, and schools. In September 1889, the Glasgows paid visits to both the St Mary's Girls' Orphanage and the Boy's Catholic Orphanage in Nelson, making inspections of each institution, while in November 1897 the Ranfurlys together with their aides visited the Magdalen Asylum in Christchurch where they made a tour of the asylum. ${ }^{246}$ On another occasion in 1892, Lady Glasgow paid a visit to Auckland Hospital where she presented certificates to a group of nurses and toured the building. ${ }^{247}$ Governors and their wives did not restrict their association to those institutions which could be termed 'deserving'. On several occasions they visited institutions which sought to help 'fallen' women or ex-prisoners, such as when Lady Plunket visited the Door of Hope for Friendless and Fallen Women or when the Islingtons in 1911 visited the Prison Gate Brigade Home. ${ }^{248}$ It appears that governors' wives were not held back from associating with organisations which could have been deemed undesirable and lacking in respectability. The existence of such institutions was indicative of New Zealand's wider welfare environment throughout the years from the 1880s to the 1920s in which charitable organisations carried out welfare work for those in need while the government maintained a minimal contribution. Visiting such homes and institutions could be seen within the context of vice-regal wives carrying out a Christian service and showing an interest in all members of society - even those who were less fortunate than most.

Governors' wives in New Zealand in the late nineteenth and early twentieth centuries played a prominent part in women's organisations providing aid and support to those in need. They provided the organisations with which they associated or participated a link to vice-regal office. Such a link could be beneficial in

\footnotetext{
244 'Veteran's Memorial Home', EP, 2 September 1902, p.2; 'Home for Veterans', EP, 10 July 1902, p.5. 245 'The Veteran's Home', NZH, 11 December 1903, p.6.

246 'Lord and Lady Onslow', NZH, 27 September 1889, p.5; 'The Visit of the Governor', Press, 13 November 1897, p.8.

${ }^{247} \mathrm{NZH}, 30$ December 1892, p.2, column 8 (supplement).

248 'The Governor', NZH, 6 January 1905, p.5; 'The Governor', Press, 14 November 1911, p.7.
} 
raising an organisation's profile and attracting others to the organisation or improving its fund raising efforts, as happened with Lady Jervois' work on behalf of the Girls' Friendly Society in the 1880s. Similarly, Lady Plunket and Lady Liverpool's actions on behalf of the two organisations which borrowed their names - the Plunket Society and the Lady Liverpool Fund - were equally valuable to each organisation as they sought to achieve their respective goals.

The three organisations described in most detail here - the Girls' Friendly Society, the Plunket Society, and the Lady Liverpool Fund - are examples of the more exceptional position that governors' wives could occupy in women's organisations. All three were organisations run largely by women for women (although the Plunket Society also aimed its programme at all of New Zealand). The three women involved in these organisations in their formative years left behind an indelible mark. They were not merely figureheads, but participated in all levels of each organisation. Lady Jervois organised fund raising events and contributed her own hand-made goods for sale or exhibition, Lady Plunket gave demonstrations on how to make humanised milk and lectured on feeding babies all over the country, and Lady Liverpool knitted for the war effort and packaged parcels herself. Through their actions and the enduring success and legacy of each society, all three governors' wives demonstrated the impact and influence that vice-regal office could have on the fortunes of a voluntary organisation.

The environment in which each of these societies existed along with their aims and goals also illuminated the gendered nature of the work that governors' wives carried out and advocated on each organisation's behalf. The GFS was focussed on providing respectable work and accommodations for newly arrived women to New Zealand or indeed any young women who needed it. The Plunket Society grew out of fears and anxieties about the quality of the New Zealand population and women's failings as mothers in the twentieth century, and the effect this would have on future generations. The Liverpool Fund meanwhile, concentrated on promoting women's own feminine work for the war effort, including rewarding and acknowledging 'mothers of empire' for the sacrifice of their sons as soldiers. In addition, the Mothers' Union advocated for women to recognise the importance of motherhood and child rearing for society as a whole. All four organisations were 
conservative in their outlook and opinions about the role of women in society, and it is telling of the position of governors' wives that they were proponents of such views at a time when women in New Zealand were achieving and agitating for greater political rights.

The work of governors' wives across the years from 1887 to 1926 indicates a shift in the focus of their work. Although they were still involved in more traditional charitable work and visited orphanages and homes for incurables, their work over these decades was also oriented towards helping new women's organisations which arose at the time. What this shift in focus suggests is that regardless of the largely conservative nature of the work undertaken by governors' wives for women's organisations, they were nonetheless influenced by the growing women's movement. As women agitated for greater rights throughout the late Victorian and Edwardian eras, regardless of the outcome, they still put women's issues to the fore. 


\section{Chapter Three \\ Dress, Decoration, and Government House}

Lady Onslow is a very nice-looking woman, apparently about 30 years of age. She is tall, and has dark hair and eyes, a fresh, bright complexion, and a particularly pleasing expression and smile. Your lady readers will be anxious to know how she was dressed, so I obtained full and precise particulars from a lady spectator, who is an authority entirely to be depended on. She gives me the following particulars:-"Lady Onslow wore a very handsome walking dress of sapphire blue velvet, with vest of white cashmere, and exceedingly pretty bonnet of the same material as the dress (sapphire velvet), with pale pink rosebuds and sprays of stephanotis; bright tan-coloured kid gloves, and shining patent leather shoes. She carried a handsome bouquet of hot-house flowers." 249

Such was the description made of Lady Onslow by the Otago Daily Times upon her arrival in New Zealand with her husband, the colony's new governor, in 1889. The appearance and dress of vice-regal wives was a common feature of newspaper reports in the late nineteenth and early twentieth centuries. So too, were detailed descriptions of the decoration of Government House for social engagements. Such reports demonstrate the public interest - or the perception on the part of newspaper editors of such interest - taken in the subjects of vice-regal office. Reports of these details also provide an insight into how governors' wives presented themselves and their families to the colonial public between 1887 and 1926. This chapter looks at the vice-regal office on show, at the display of an elite position and status, and how the position of governors' wives was conveyed through the elaborate and impressive scale of dress and decoration.

Material objects, such as furniture, clothing, jewellery, and housing, give meaning to the people who use them and in turn, are vested with meaning through use. They express their tastes, ideals, class, gender, and other aspects of identity. As such, they are a rich source for historical enquiry. Through material objects, new or more complex understandings of the human subjects of history are possible. This is particularly true of the British Empire during the late Victorian and Edwardian periods, a point in time where the Empire was at its strongest, and imperial display

249 'Our New Governor at Wellington', ODT, 3 May 1889, p.2. 
and performance through objects formed a significant part of the imperial project. Governors and their wives, as vice-regal representatives in the colonies, played a substantial part in imperial display and ceremony. Examining the material objects of governors' wives in New Zealand in this period - both their dress and the decoration and use of Government House - provides an opportunity to investigate how governors' wives presented themselves to the colonial public. It also provides for a consideration of how such displays were a subject of interest and how they were interpreted by newspaper readers and the New Zealand public between 1887 and 1926.

Dress played a significant part within the spectacle of the British Empire. Helen Callaway described how the practice of imperial rule resulted in a total cultural mode whereby grand government buildings were built, principal streets named after British sovereigns, and a strict hierarchy of the ruling class observed. ${ }^{250}$ Dress was likewise a means of imperial domination. For the Empire's colonial officials overseas, correct British dress set them apart from those over whom they ruled. Their dress gave imperial representatives authority and power, and assisted them to carry out their official functions. It was also an important signifier of position during imperial ceremonies, such as coronation or royal birthday celebrations or the opening of Parliament. For the governor, military uniform was generally worn on such occasions. In 1925, reporting on the opening of Parliament, the New Zealand Herald described then-Governor-General Sir Charles Fergusson as wearing "the scarlet uniform and befeathered hat of a general officer in full dress". ${ }^{251}$ Other reports generally only noted that the governor was in full military uniform without adding specifics. ${ }^{252}$ For imperial men, their authority and masculinity was emphasised and heightened through the military uniform, which symbolised greater power through its martial meaning and its elaborate decorative elements. ${ }^{253}$ The men's uniform distinguished them from their wives who, although able to exercise

\footnotetext{
250 Helen Callaway, 'Dressing for Dinner in the Bush: Rituals of Self-Definition and British Imperial Authority', in Ruth Barnes and Joanne B. Eicher (eds.), Dress and Gender: Making and Meaning in Cultural Contexts (Oxford: Berg Publishers, 1992), p.239.

251 'Parliament', NZH, 26 June 1925, p.11.

252 See, for example: 'The Opening of Parliament', Press, 24 June 1892, p.5; 'Opening of Parliament', Press, 24 June 1899, p.8; 'Opening of Parliament', Press, 22 August 1906, p.7.

253 Callaway, 'Dressing for Dinner in the Bush', p.242.
} 
more choice in design, colour, and fabric, remained tied to conventions around respectable female dress. ${ }^{254}$

For women in the Empire, particularly those married to high ranking men, dress was equally significant, particularly as a marker of their femininity. Callaway stated that, "[i]f the prescribed dress of the male colonial officers was characterized by pomp and plumage enhancing masculinity, that of their wives was marked by propriety and femininity."255 Wives' dress was also judged for its taste and the extent to which it matched the extravagance and spectacle of vice-regal office. Chapter one of this thesis discussed the position of governors' wives in official ceremony and noted that other than being present, little was required of them at official events. Their dress, and how they presented themselves to colonial society through their appearance, thus took on added significance.

Scholars have noted the importance of dress to the vice-regal wife's position, often citing the example of Lady Curzon. The vicereine of India between 1899 and 1905, Lady Curzon designed a range of gowns for the 'Delhi Durbar' celebrations of King Edward VII's coronation. Among the gowns was a famous and intricate clothof-gold gown heavily embroidered with metal threads and emeralds in a pattern of peacock feathers. ${ }^{256}$ According to her biographer, Lady Curzon went to great lengths when preparing her India wardrobe, being careful to be seen as "ultra-feminine when the men were ultra-masculine."257 Lady Aberdeen was likewise aware of her self-presentation via her dress when she was a vice-regal wife. At one ball Lady Aberdeen wore a gown in blue and white with a red-lined train. The dress was embroidered with designs from the Irish 'Book of Kells', which, according to McLeish, "reflected the imperial theme of the ball and her interest in Ireland".258 Dress was one of the ways in which governors' wives were seen, and provided a means for them to display an imperial identity.

\footnotetext{
254 Ibid.

255 Ibid.

256 Ibid, p.241. See also, Valerie Mendes and Amy de la Haye, 20th Century Fashion (London: Thames \& Hudson, 1999), p.27.

257 Nigel Nicolson, Mary Curzon (London: Wiedenfeld and Nicolson, 1977), p.138, in Callaway,

'Dressing for Dinner in the Bush', p.242.

258 McLeish, p.258.
} 
Dress was not the only means of presenting imperial spectacle and ornamentation to the colony. As the official residence of the Governor, Government House was a key site for the display of vice-regal ceremony. The House was where governors and their wives hosted coronation or royal birthday balls, receptions, 'at homes', investitures, and garden parties. It was an imperial and social space. It was also a family space. As the vice-regal residence, Government House acted as the private home of the governor and his family. They slept, lived, and ate there, and in some cases, governors' wives even gave birth there. ${ }^{259}$ As both a private family space and a public imperial space, the decoration and display of Government House illustrated both the private concerns of the vice-regal family as well as their public identity as representatives of the monarch.

In New Zealand, there have long been two Government Houses, one in Wellington and the other in Auckland. By the year 1887, Government House Auckland was on its third incarnation (the first two were destroyed by fire in 1848 and 1857 respectively). ${ }^{260}$ The third Auckland House was built in 1856 and served as a vice-regal residence until 1962 when the present-day Government House in Auckland was acquired. The old Government House became part of the University of Auckland in 1969.261 Similarly, the residence in Wellington that served as Government House in 1887 was not the first the city had boasted. This second Government House was built in 1868, and it became the primary residence of the governor and his family after Wellington became the capital in $1865 .{ }^{262}$ This residence was a large timber mansion built in the Italian style and it stood on the present-day site of the Executive Wing of Parliament Buildings (the Beehive). In 1908 after a fire destroyed Parliament, Government House became the site of parliamentary business for the next ten years and the governor moved into a

\footnotetext{
259 In February 1909, Lady Plunket gave birth to a son at Government House in Palmerston North. See, 'Lady Plunket. Birth of Another Son', NZH, 8 February 1909, p.5.

260 'Other Government Houses', http://gg.govt.nz/content/other-government-houses; accessed 12 May 2015.

${ }^{261}$ Ibid; 'Government House Auckland', http://gg.govt.nz/government-house/other; accessed 12 May 2015.

262 'Other Government Houses', http://gg.govt.nz/content/other-government-houses; accessed 12 May 2015.
} 
residence in Palmerston North. ${ }^{263}$ In 1910, the governor moved back to Wellington and into a newly built residence opposite Wellington's Basin Reserve. ${ }^{264}$ This House remains the current vice-regal residence in Wellington.

In New Zealand, the dual role of Government House as both a private family residence and public imperial space resulted in a complicated history of furnishing until the early twentieth century. In the late Victorian period, only the public spaces of the houses were furnished by the New Zealand government. Governors were required to bring out their own carriages, horses, cars, and certain household items. ${ }^{265}$ When a governor departed, he often tried to sell the furnishings he supplied to the incoming governor or the government. Failing that, they were sold at auction or else put in the House outbuildings. ${ }^{266}$ As the twentieth century progressed, however, the government began to provide more of each House's furnishings. This was particularly the case once the new Government House in Wellington was built in 1910. ${ }^{267}$ The government did not, however, appear to enjoy maintaining the Government Houses. McLean stated that items such as linen or glassware were replaced in the Houses only every five or six years, and described the slow bureaucratic system - which included checking the availability of public funds - that formed a part of this process. ${ }^{268}$

Furnishing Government Houses could be a point of contention between governors and the New Zealand government. The Plunkets were one vice-regal couple who dealt with the government over the furnishings in Government House. In a letter to then-Minister for Public Works Sir William Hall-Jones in 1905, Lady Plunket described many aspects of the House that she thought needed improvement. In particular, she was concerned about the carpets: "I am going to beg - I find we can

\footnotetext{
263 Martin, pp.136-137, 155; 'Other Government Houses', http://gg.govt.nz/content/othergovernment-houses; accessed 12 May 2015. This building eventually came to form a part of the Massey University campus.

264 'House and Grounds', https://gg.govt.nz/government-house/house-and-grounds; accessed 12 May 2015.

265 McLean, p.364.

266 Ibid. Sir William Jervois sold a carriage, horses, and other personal effects at auction before his departure from New Zealand in 1889. The sale of the carriage and the horses resulted in some bad feeling after members of the Roman Catholic community, thinking they had secured the items, discovered that they had in fact been sold to someone else. See: 'Homeward Bound', NZH, 19 March 1889 , p.5.

267 McLean, pp.364-365.

268 Ibid, p.365.
} 
not do without a carpet in the back drawingroom. The rugs I counted on are too small \& too few." 269 Lady Plunket also had concerns about other features in the House and explained that Lord Plunket was in the process of sending a formal application to the Public Works department with regard to changing elements of the House. Her letter was in addition to this application as "I am sure my way of stating the case is much more human."270 The result of the Plunket's application is unknown. But whenever refurbishments were carried out, it seems that governors' wives were able to choose some of the furnishings themselves. In 1911 Lady Islington spent time in Auckland choosing hangings and wallpapers for a refurbished Government House Auckland.271

Along with the dress of governors' wives, the furnishings of Government House provide an opportunity to examine how the women who inhabited the viceregal residence in the late nineteenth and early twentieth centuries chose to decorate and dress as part of the display of vice-regal office. Newspaper reports of the time were incredibly detailed in their description of vice-regal dress and the decoration of Government House on social occasions. That such details were included in reports of vice-regal happenings indicates the importance of dress and material display to the public consumption of vice-regal office. The ornamentation and display of governors' wives and Government House was of interest to the public. Reports of dress and decoration allowed readers to appraise how well or otherwise governors' wives were fulfilling their duties. Whether the wives were extravagant or economical, a social success or failure, or had good or bad taste could be judged by the reading public. Newspaper reports also provided the public, especially those who were not invited, with an account of the event. Through such reports an opportunity arises to tease apart the meanings of the objects and clothing on display in the imperial house and on the body.

The arrival of a new governor to New Zealand was a moment of great interest and curiosity. An important ceremonial and constitutional occasion which also marked the first moment that the governor and his family were seen by the people

\footnotetext{
269 Victoria Plunket to Sir Hall-Jones, 3 August 1905, Letter concerning refurbishment of Government House, MS-Papers-5755-73, ATL, Wellington.

270 Ibid.

271 'Lady Islington's Visit', NZH, 19 January 1911, p.6.
} 
of the colony, the arrival ceremony was crucial in the formation of first impressions. Newly arrived governors and their wives were figures of intense public interest and they were expected to make a suitable impression appropriate to the office they were about to take up. On the part of the governor, first impressions were conveyed through a combination of his appearance, his speaking skills, and his conduct when taking the oaths of office and replying to addresses of welcome. On the part of the governor's wife, this was done primarily through her appearance. Returning to Lady Onslow's arrival in New Zealand in 1889, what strikes the reader is the interest taken by the reporter in communicating details of her apparent age (she was then about 37 years old), her complexion, colour of her hair and eyes, height, and expression. In addition to this, significant attention was paid to her dress.

The level of detail paid to governors' wives' appearance upon their arrival in New Zealand was a common feature of newspaper reports across the years 1887 to 1926. As well as describing Lady Onslow's looks and dress, the papers reported on the dress and physical features of several others, among them Lady Ranfurly in 1897, Lady Plunket in 1904, Lady Liverpool in 1912, and Lady Jellicoe in 1920, on the occasion of their respective arrivals in New Zealand. ${ }^{272}$ The detailed level of description served to inform the reader about the governor's wife. Her clothing and appearance acted as her introduction to local society and was the means by which she was presented to the reading public. Her position as a governor's wife was communicated through her dress. For example, Lady Ranfurly wore satin and lace, a long sable cape, and large diamond earrings and brooch when she arrived in New Zealand. ${ }^{273}$ The richness of her dress, particularly the sable cape and diamond jewellery, spoke to her wealth and elite status as both a governor's wife and an aristocratic lady. Likewise Lady Jellicoe wore fox furs and Lady Plunket a moleskin and ermine pelerine (short women's cape) when they first arrived. ${ }^{274}$ The moment of arrival in New Zealand was an opportunity for the vice-regal lady to establish her position as wife of the monarch's representative through her physical appearance and the expense of her outfit.

\footnotetext{
272 Iolanthe, 'Lady Correspondents. Wellington', Press, 27 August 1897, p.2; 'Our New Governor', ODT, 21 June 1904, p.3, column 3; 'Lady Liverpool', EP, 19 December 1912, p.8; 'Lady Jellicoe', EP, 27 September 1920, p.8.

${ }^{273}$ Iolanthe, 'Lady Correspondents. Wellington', Press, 27 August 1897, p.2.

274 'Our New Governor', ODT, 21 June 1904, p.3, column 3; 'Lady Jellicoe', EP, 27 September 1920, p.8.
} 
Although reports of the wives' dress at the arrival ceremony were the main means by which governors' wives were first presented to the New Zealand public, on occasion other articles did provide further information about the new vice-regal family. Many such articles were written in advance of the arrival of the governor and his wife to New Zealand, shortly after his appointment to office had been announced. In November 1888, the New Zealand Herald reported on the background of the incoming Onslows whose term would not begin until May the following year. The article noted that Lady Onslow was the eldest daughter of Lord Gardner and that she and her husband had three children. ${ }^{275}$ The article also gave details about Lord Onslow's family background and estate. Similarly, the women's column of the Evening Post provided details about Lady Ranfurly before she and her husband took up office in August 1897. The article mentioned her physical features while noting that "[ $t]$ hough too nervous to really enjoy horseback exercise, Lady Ranfurly is an adept at boating, skating, and tobogganing" and that she also enjoyed painting watercolours, music, and reading. ${ }^{276}$ Although such reports provided details about incoming governors' and their wives, the fact remains that the wives were chiefly introduced to the public through the description of their appearance at arrival ceremonies.

Richness of dress is a repeated element in the outfits worn by governors' wives during their years in the position. Whether at balls, 'at homes', or garden parties, governors' wives were distinguished by their clothing. On the occasion of Queen Victoria's birthday in 1889, the Mayor and Mayoress of Wellington (Mr and Mrs Duthie) threw a ball in honour of the vice-regal representatives at which Lady Onslow "wore a magnificent costume of white Ottoman silk with satin stripes, a tiara of diamonds, and clusters of diamonds on the back and front of her corsage, and a diamond necklace."277 At a coronation ball for King Edward VI in 1902, Lady Ranfurly:

was a brilliant figure in exquisite ivory brocade, with soft frills of fine old lace, and touches of gold embroidery on the small flounces at the foot of the skirt. Great velvet roses of varying tints were fastened on

\footnotetext{
275 'The New Governor', NZH, 8 November 1888, p.5.

276 'Our New Governor's Wife', EP, 7 August 1897, p.2 (supplement).

277 'The Mayor's Ball', EP, 25 May 1889, p.2.
} 
the left shoulder. With this gown she wore her beautiful diamonds and emeralds. ${ }^{278}$

Lady Plunket also dressed richly for the first ball given by herself and her husband at Government House Wellington. The Otago Daily Times described her outfit as a:

charming frock ... of ivory mouseline de soie, accordeon [sic] pleated, trimmed with garlands of ruched silk. A berthe of exquisite lace over chiffon was worn on the low bodice, and a swathed bell of shaded pink satin gave a soft touch of colour to the pretty gown. Lady Plunket's ornaments were a diamond necklace and a set of diamond stars on tulle about her neck, and a diamond tiara. ${ }^{279}$

Through the obvious expense and intricacy of their gowns at balls, governors' wives were able to demonstrate their position and status to society. The inclusion of diamonds and other jewels - particularly tiaras - to their outfits further identified them as women married to the monarch's representative. Such elaborate and expensive dress also indicated that they were women accustomed to and equipped to mix in elite circles. When attending formal social events at which people of high status and rank dominated, elaborate and expensive dress and jewellery were prerequisites. In displaying such attributes at formal imperial social events, governors' wives communicated their suitability and worthiness as representatives of vice-regal office.

Different occasions required different levels of dress. As more elaborate and exclusive events to attend, balls were occasions when governors' wives dressed in their finest outfits and accessorised with their most valuable jewellery. Garden parties, 'at homes', and the races, all of which usually took place during the day time, were more relaxed affairs and the outfits worn reflected the more casual context. In 1891 Lady Onlsow held a garden party at which she wore "a pale fawn-colored dress, trimmed with gold embroidery, small feather boa, and pretty bonnet of gold and brown", while at her first 'at home' in 1904, Lady Plunket wore "a very dainty grey frock with much lace and tucking". ${ }^{280}$ In 1924 when attending the Riccarton races, Lady Jellicoe wore a simple outfit, a "smart grey tailored costume and a wide-

\footnotetext{
278 'The Coronation Ball', EP, 7 August 1902, p.5.

279 'Ball at Government House', ODT, 9 July 1904, p.8

280 'Garden Party at Government House', Press, 28 October 1891, p.5; Priscilla, 'Ladies' Column', EP, 9 July 1904, p.11.
} 
brimmed hat trimmed with big bows." 281 While still elegant garments, the context of a day time event resulted in a more relaxed and simple outfit, appropriate for the occasion. Governors' wives were careful to dress to the occasion and to do so with skill and good taste. In doing so, wives took the lead as exemplars of proper dress suitable to the occasion. Setting the appropriate example demonstrated the extent to which governors' wives upheld the dignity of vice-regal office.

The opening of Parliament was another event at which the style of dress was matched to the different context. On these occasions, governors' wives tended to dress in a more sedate and refined fashion in line with the business-like tone of the event. At the opening of Parliament in 1899 Lady Ranfurly wore a simple violet dress and a matching hat with grey feathers, while in 1906 Lady Plunket wore "a beautiful mauve dress of fine cloth, and a hat with long mauve feathers". ${ }^{282}$ This convention continued through the years with Lady Jellicoe, in 1922, wearing "a dress of black, with crepe lace and ninon, and a wide black hat with feathers." 283 Parliamentary ceremonies were not the only events which required a certain style of dress, however. Lady Plunket was an honorary colonel of the No.2 North Canterbury Rifles and when she reviewed her regiment in 1909, not only did she salute perfectly, but she wore her “colonel's uniform” when doing so. 284

A clear difference exists between reports of governors' wives' dress at ceremonial and social events and those linked to their work for various charitable and imperialist organisations. Articles reporting on Government House balls, 'at homes', or the opening of Parliament to name but a few were numerous and detailed in their description of the vice-regal lady's dress. Reports of what she wore when attending events associated with charitable or women's societies were, by way of contrast, scarce. When such events were ceremonial or a spectacle of some sort, newspapers did occasionally mention the clothing worn by the wives. In June 1901, Lady Ranfurly formally opened a bazaar to raise funds for the Home for Incurables, and the New Zealand Herald noted that she "looked charming in her trailing black

\footnotetext{
281 'Dresses at Riccarton', Press, 18 August 1924, p.2. 282 'Opening of Parliament', Press, 24 June 1899, p.8; 'Opening of Parliament', Press, 22 August 1906, p.7.

283 'Parliament', Press, 29 June 1922, p.6.

284 ODT, 9 October 1909, p.9, column 4. Sadly, a more detailed description of this outfit does not seem to appear in the pages of the newspapers.
} 
frock, with sequined bodice, sable furs, and picturesque wide black hat." 285 Similarly, at a 'Spanish Cabaret' featuring various dance performances and a supper held to raise funds for the Girl Guides in August 1924, Lady Jellicoe was noted to have worn "a trained gown of cameo pink souple satin, with shoulder straps and large buckles of brilliants", with rose pink fringe falling from the buckles at the shoulders. ${ }^{286}$ These two examples are some of the only occasions where the dress of governors' wives was noted in relation to their association with welfare or female organisations. The type of event - in these cases public entertainments to raise funds - appears to have determined whether dress was reported on in relation to governors' wives' welfare and other work. By way of comparison, reports of what they wore to meetings they attended or institutions they visited were rarely mentioned.

The paucity of reports of what was worn to meetings of organisations or visits to institutions makes it difficult to know what was worn on these occasions. The mere fact of the absence of governors' wives' dress in articles detailing such events, however, coupled with these event's contexts, suggests that their dress was likely to have been less spectacular in design, fabric, and accessories than outfits worn to balls for example. Additionally, it seems probable that the outfit worn had likely been worn before and was therefore not worth reporting in any detail. In part, this reflects the need to dress appropriately for the context and the occasion. Wearing expensive silk, lace, fur and diamonds to visit a home for destitute persons would have been considered highly inappropriate. The non-inclusion of vice-regal dress in reports of meetings or visits to institutions also reflects the relative importance of clothing to successfully carrying out vice-regal duties. At balls, parties, or the opening of Parliament, extravagant and expensive dress was a crucial component in the aspect of ornamentation played by governors' wives. On these occasions the wives were seen to inhabit and fulfil the expectations of the spectacle of office. When attending or convening meetings of organisations or visiting institutions, however, governors' wives were focussed on a different aspect of their position, one that did not require a sartorial spectacle in order to be a success.

285 'Other Function', NZH, 19 June 1901, p.5.

286 'Eastern Cabaret', Press, 15 August 1924, p.2. 
The type of event was not the sole factor contributing to what governors' wives wore in public. As well as dressing for the event, the wife's own personal taste and age played a part in her outfit, as did the time period in which she was the governor's wife. Lady Jervois, for example, who was already at least 50 years old in 1883 when she arrived in New Zealand with her husband, ${ }^{287}$ generally wore black or dark hues on the rare occasions her outfits were described by the papers. ${ }^{288}$ This is perhaps due to her age and quite possibly her working class background as the daughter of a builder. ${ }^{289}$ Though Lady Jervois always fulfilled her duties, her simple dress and decision to leave Government House when Sir William was away (see below for further details) while in the position suggest that she was not entirely comfortable with her elevated status as a governor's wife. On the other hand, both Lady Ranfurly and Lady Plunket, aged 39 and 31 respectively when they arrived in New Zealand, dressed richly, in gowns of colourful fabrics with extensive detailing, accessorised by expensive jewels. ${ }^{290}$ The intricacy and complexity of their dress was due in part to the fashions of the later Victorian and early Edwardian periods, but their age and aristocratic backgrounds also contributed to the extravagance of their dress.

As the twentieth century progressed, so too did the fashions. Lady Liverpool, who held the position of governor's wife for eight years, arrived in New Zealand in 1912. Her dress was much simpler than the Ladies Ranfurly and Plunket. When she arrived in New Zealand the Evening Post described her outfit in strong terms as "severely plain". ${ }^{291}$ She wore "a grey coat and skirt ... a little Peter Pan collar of lace

\footnotetext{
${ }^{287}$ Lady Jervois' exact age is unknown. Records concerning Lady Jervois are generally scarce and searches in The Times show that her birth was not publically notified. Her husband was born in 1821 and they were married on 19 March 1850, when Sir William was 28 or 29 years old. Lady Jervois died in 1895 , but her obituary mentions neither her birth date nor age at death. Assuming she was at least 20 years old when she married Sir William, Lady Jervois would have been 53 in 1883 when she arrived in New Zealand as a vice-regal spouse (see 'Obituary', The Times, 19 March 1895, p.10; 'Obituary', The Times, 18 August 1897, p.7; and 'Married', The Times, 23 March 1850, p.9). ${ }^{288}$ At both the opening of Parliament and a football match, Lady Jervois dressed in black. See: Dorothy, 'A Lady's Letter from Wellington', NZH, 18 May 1888, p.1 (supplement).

${ }^{289}$ Sir William's biographer in the Oxford Dictionary of National Biography described Lady Jervois as "the daughter of William Norsworthy, a London builder from Devon". See John S. Kinross, 'Jervois, Sir William Francis Drummond (1821-1897)', Oxford Dictionary of National Biography, updated May 2009; doi:10.1093/ref:odnb/14800; accessed 7 November 2014.

${ }^{290}$ For descriptions of both ladies' dress, see: Priscilla, 'Ladies' Column', EP, 12 August 1905, p.15; 'Ball at Government House', Press, 5 September 1907, p.4; Iolanthe, 'Lady Correspondents', Press, 2 September 1897, p.2.

291 'Lady Liverpool', EP, 19 December 1912, p.8.
} 
and a black silk bow finishing the coat at the neck. Her small black straw hat, of a mushroom shape, had a little frill of white lace laid round the brim, and was massed with purple velvet clematis." 292 To a wedding ceremony in 1919 she wore "a fawn costume and white hat swathed with ostrich feathers", while at a reception to the future governor Admiral Viscount Jellicoe of Scapa, she wore "a dress of golden brown charmeuse, with furs, and a biscuit-coloured hat trimmed with brown wings." 293 The stark difference between Lady Liverpool's dress and that of her predecessors can perhaps be explained by personal taste and the time period in which she was a governor's wife, a time, that is, when fashions underwent rapid change, not least in part because of the impact of World War One. ${ }^{294}$ In the years from 1914 to 1918 dress became a matter of public significance, and extravagant, expensive and showy dress would have been considered unpatriotic. Lady Liverpool dressed in a manner that fit the public mood, again displaying awareness of the suitability of dress and the need to uphold the dignity of vice-regal office through dress.

As well as examining the details of dress given in newspapers, looking at the way in which governors' wives' dress was reported also sheds light on the vice-regal lady's position in society. Newspaper articles described the outfits worn by women at particular events in a list format, the list arranged according to the social hierarchy of the colony. As the head of society and a figure of public interest the governor's wife was almost always listed first, followed by those next in social prominence. In the Press' segment on the Canterbury Cup Day in 1891, which would "long be remembered as one of the most brilliant gatherings witnessed in Canterbury", nearly an entire column was devoted to detailing the outfits worn to the event. Lady Onslow was described as wearing "a rich white silk floral design of sprays of blue and pink flowers, the bodice, skirt, and jupon being trimmed with pale pink. The bonnet to match was of pale pink heather." ${ }^{295}$ Her outfit was listed first, followed by those of lesser importance. Last in the list was Mrs J. Anderson in "a

\footnotetext{
292 Ibid.

293 'Women's Corner', Press, 29 September 1919, p.2; 'Reception to Lord Jellicoe', EP, 23 August 1919, p.9.

294 On changing women's fashion during World War One, see Mendes and de la Haye, pp.48-55.

295 'The Dresses', Press, 10 November 1891, p.6.
} 
black and white check dress". ${ }^{296}$ This was a common way of detailing the outfits worn to an event. An account of Lady Ranfurly's first week in the colony and the social events she and Lord Ranfurly attended or hosted went to great length to describe the Countess' dress, and it was not until later in the article that others' outfits were mentioned.297 This trend continued from 1887 to 1926, with a description of Lady Fergusson's dress at the 1926 Hunt Club Ball given first, before any other ladies' outfits. ${ }^{298}$ Such lengthy reports served to emphasise the elevated position of the governor's wife relative to other women in the colony at the same time as readers were informed as to current fashions in design, colour, fabric and accessories.

There are only a few exceptions to this rule: when royalty visited New Zealand, and, occasionally, when an event was hosted by a woman other than the governor's wife. In 1901, when the Duke and Duchess of York - the future King George V and Queen Mary - visited New Zealand as part of a tour of the Empire, Lady Ranfurly came second in both proceedings and the women's columns. At a royal reception given to the Duke and Duchess at Government House in Auckland, the royal couple received the guests, rather than the Governor and Lady Ranfurly. Likewise, description of the Duchess' outfit came before that of Lady Ranfurly, one of the rare occasions that this happened in newspaper reports. ${ }^{299}$ One other example of the governor's wife coming behind others in precedence was in 1925 when the American Consul-General gave an 'at home' to visiting admirals and officers of the American fleet then in New Zealand. On this occasion, Lady Fergusson's dress was described after Mrs Lowrie's (the hostess), and other guests followed after her. ${ }^{300}$ What these rare exceptions suggest is that the governor's wife only took precedence when she was the highest ranking woman present. The Duchess, as a member of the royal family, came before the Countess of Ranfurly by reason of rank. ${ }^{301}$ In the other

\footnotetext{
296 Ibid.

297 Iolanthe, 'Lady Correspondents', Press, 2 September 1897, p.2.

298 'Hunt Club Ball', Press, 11 August 1926, p.2.

299 'Government House Functions', Press, 13 June 1901, p.5

300 'American Consular Reception', EP, 13 August 1925, p.9.

301 The issue of precedence was a complex one, especially where vice-regal representatives and members of the royal family were concerned. The question arose in 1920 when the Prince of Wales undertook a royal tour of New Zealand. McLean described how Lord Liverpool offered to cede precedence to the Prince, but that King George V declined as Liverpool was his own representative and could not therefore cede precedence, even to the heir to the throne (McLean, p.181). Governors'
} 
example noted, Lady Fergusson came second not because the wife of the American Consul-General out-ranked her, but because Mrs Lowrie was the hostess, and moreover, was a foreign hostess, not falling under Lady Fergusson's jurisdiction, as it were.

A further element of newspaper reports which indicates the primacy afforded to the governor's wife was the level of detail which went into the description of her dress. The vice-regal lady's outfit was always described at length while others were lucky to get more than a handful of words. The Otago Daily Times devoted a detailed description of the outfit Lady Onslow wore to the New Zealand and South Seas Exhibition in 1889, noting that she "presented a charming appearance in a lovely costume of flesh pink silk richly trimmed with white lace, with a bonnet to match surmounting her dark hair, a white lace parasol, and long white fur boa." Compared with this, ladies further down the column barely rated a mention: there was a "Mrs Mackerras-Black silk costume" and a "Mrs Boyd-Dark green costume." 302 Similarly, reports of Lady Plunket's dress at the annual Wellington Garrison Officers' Ball were lengthy compared to others. The Evening Post noted that her "graceful gown was of black chiffon velvet, the bodice being much trimmed with jet and outlined with folds of white tulle, which also formed the frills of the pretty sleeves. An exquisite diamond tiara and necklace were worn", while Miss Seddon wore "a blue satin with much insertion and lace about it", and Mrs Collins, "black silk and jet". ${ }^{303}$ In devoting column space to detailing governors' wives' dress, newspapers reinforced the influence and elevated status of vice-regal wives as figures of public interest in New Zealand society.

The attention given to the dress of governors' wives by newspapers indicated the importance of dress in discharging vice-regal office. The governor's wife had no unique uniform of her own to mark her position in the vice-regal establishment. Her

wives were a different category. Although married to the monarch's representative, they had no official position. Their position in precedence seems to have mostly been determined by their rank separate to that as vice-regal wives. A report in the New Zealand Herald in 1903 illuminated the issue. Titled ladies decided not to curtsey to Lady Curzon, wife of the Viceroy of India, because, "Lady Curzon, by strict precedence is merely the wife of an Irish baron of most recent creation. For the Duchess of Portland or the Duchess of Malborough to curtsey to her would be to elevate her to Royal rank. It would create a most inconvenient precedent." ('Lady Curzon Ignored by the Duchesses', NZH, 21 February 1903, p.1).

302 '“Alice's" Description of the Dresses', ODT, 27 November 1889, p.2.

303 'Garrison Officers' Ball', EP, 6 July 1904, p.2. 
dress did that for her. The richness, expense, and embellishments of her clothing marked the wife out as a person of importance in the country and spoke to her position as a representative of the monarch. Brocades, lace, silk, chiffon, beads and jewels all formed a part of the wardrobe of governors' wives between 1887 and 1926. Dress contributed to the ornamental aspect of being governors' wives. Seeing what the governor's wife wore to an event was also a moment of high anticipation on the part of attendees of social engagements. The Press described how, upon the arrival of the Governor and Lady Onslow at the 1891 Canterbury Cup Day, "the attention of the ladies was divided between watching the race and endeavouring to see how the Countess looked."304 The opening of Parliament by the governor marked another moment of interest in the governor's wife. Newspapers wrote that the ladies who attended the ceremony did so in large part to see the governor's wife. The Evening Post was blunt in its explanation of this situation: "to speak truly, the function loses half its interest to women when the Governor is unaccompanied."305

That newspapers reported on vice-regal dress suggests that editors thought the details would be of interest to the public. The positioning of reports in newspapers likewise indicated who among the New Zealand public editors thought would be most interested in such subjects. The vast majority of reports on governors' wives dress and the decoration of Government House were contained in articles forming part of various women's columns. But reports on dress could also appear in articles that were more political in nature, such as those detailing the ceremonies for the opening of Parliament or the taking of the oaths of office by the governor upon his arrival. In these articles, the reporter would often turn to a lady friend' or 'lady spectator' to ensure they correctly described the governor's wife's dress. The reporter who detailed the Onslows' arrival to New Zealand did just that, noting "[y]our lady readers will be anxious to know how she was dressed, so I obtained full and precise particulars from a lady spectator, who is an authority entirely to be depended on."306 That newspapers acknowledged and assumed that their women readers would be interested in the details of vice-regal dress, and that such details were confined either to women's columns or highlighted as being for

\footnotetext{
304 'The Dresses', Press, 10 November 1891, p.6.

305 'Girls' Gossip', EP, 1 July 1905, p.15.

306 'Our New Governor at Wellington', ODT, 3 May 1889, p.2.
} 
women readers when in other sections of the paper, indicates the slightly patronising view of reporters and editors as to women reader's principal interest in newspapers and current events.

In addition to reporting on the clothing choices made by governors' wives, newspapers also reported, in detail, on the design and decoration of Government House. Occasionally they devoted more attention to the interior design of the House than the dress of the occupants. The Press, for example, was effusive in its description of the layout and decoration of the House for the Queen's Birthday Ball in 1898:

Under Lady Ranfurly's artistic eye quite a transformation had been wrought in Government House. As we enter the long corridor, with its delicately coloured walls and white ceiling lit by beautiful brackets of electric lights, designed by Lady Ranfurly herself, we scarce recognise it for the same place. The ballrooms, a harmony of yellow and white, have undergone a complete transformation. ... In the conservatory the lights are half-veiled with a delicate tracery of green leaves, and among the foliage are many foreign plants. The long verandah is curtained with the flags of many nations, and there are many cushioned nooks and corners for the sitters out, who from here can watch the gay scene in the ballroom beyond. ... The whole function is on a unique and lavish scale, and Lady Ranfurly may justly feel proud of the arrangements and decorations, all of which have been carried out under her own personal supervision. ${ }^{307}$

The newspaper also went to great length to describe the many plants, including tall palms and bamboo, used to decorate the House, as well as the curtains and other ornaments placed on display by Lady Ranfurly for the event.

At the first ball given following Lady Plunket's return from a visit Home in 1907, the Press made note of the decorations: "[t]he rooms were beautifully decorated, wattle from Hawke's Bay being used in masses. Palms, banana trees, tree ferns, and cut flowers were also used with fine effect."308 Lady Islington also decorated lavishly. In 1910 she and Lord Islington gave a large reception at Government House which the Evening Post described in detail:

On entering the ballroom one was cheered by a sense of warmth and colour in contrast to the southerly 'buster' which prevailed outside: rich, crimson, brocaded curtains draped the windows, and the floor 
was covered by mole-coloured velvet pile carpet, and there were plenty of brilliant electric lights-altogether most attractive after the dark and stormy drive up to the house. ... Flowers were in profusion everywhere, a particularly fine stand of gloxinias being at one end of the drawing-room. There were many dainty and electric lamps standing about on the tables, with cream silk shades, and, in many cases, flowers banked around them with a very pretty effect. 309

Similarly, the Fergussons put on a spectacle when they threw their first ball at Government House Auckland in 1925. Coloured lanterns were strung up above the lawn while the terrace was decorated with gold, rose, pink and blue coloured fairy lights. Inside were "hanging fern-baskets, rose-shaded lights, clumps of dwarf bamboo, hydrangea, and festooning lycopodeum". 310

Much like governors' wives' dress at ceremonial and social events, the display of Government House at balls, receptions, and 'at homes' was part of the spectacle and ornamentation of the vice-regal position. Having the ability to entertain lavishly and tastefully was an expected duty of the governor and his wife. Invitations to Government House social engagements were some of the most anticipated and sought-after by New Zealand society. The scale of entertainment had to meet these high expectations. Partly this was accomplished through the presence and charm of the governor and his wife, but it was also due to whether each room was appropriately decorated. As the wife of the representative of the monarch, hosting and entertaining formed an important part of the vice-regal wife's duties, and the success or otherwise of an event fell on her shoulders, as the governor would be judged by both his success in his constitutional position as much as the social side of the office.

The entertainments provided at Government House functions also formed a part of the spectacle of display provided by governors' wives. Bands played at balls, governors and their wives opened the dancing, and on occasion governors' wives themselves performed for their guests. In 1901 the Ranfurlys threw a concert for sailors and their families at Government House Wellington. After the Governor and Lady Ranfurly had welcomed them, Lord Ranfurly informed his guests that they were there to enjoy themselves and encouraged them to "light up" as tobacco (the

309 'Reception at Government House', EP, 12 December 1910, p.9.

310 'Vice-Regal Ball', NZH, 17 April 1925, p.10. 
"good strong stuff") was passed around in liberal quantities. ${ }^{311}$ Lord Ranfurly joined in the smoking with his own "well-seasoned briar". ${ }^{312}$ The concert then began in earnest, the Herald noting that "[ $\mathrm{t}]$ here were songs and recitations and instrumental music, and some delightful old chanties sung by the sailors themselves." 313 Lady Ranfurly was even persuaded to sing, and "when they cheered and asked for an encore, she gave them a pretty ditty, "The Yellow Rose of Texas."'314 Through mixing with their guests, governors and theirs wives displayed their charm and affability and Lady Ranfurly her own feminine accomplishment - which helped to validate their position as holders of vice-regal office. In addition, that the guests were navy men at a time when the Empire was fighting in South Africa, demonstrated the Ranfurlys' patriotic commitment to the war.

Events for children were occasionally held at Government House and similarly provided governors and their wives a chance to put on a vice-regal display. In March 1891, the Onslows invited pupils of the Albert Street School to afternoon tea at Government House Auckland. The children were entertained with lolly scrambles and participated in races and other games on the lawn, before the Governor and Lady Onslow waited on them for afternoon tea. ${ }^{315}$ Of Lord and Lady Onslow, the Herald remarked that they "took a very vivid interest in the children, and everything connected with them" and also "exerted themselves to the utmost to entertain the children". ${ }^{316}$ On other occasions, children were invited to a fancy dress party at Government House, and in 1911 a children's party for about 200 guests was held and hosted by the Islington's and their daughter Joan (then thirteen). ${ }^{317}$ Engaging with their guests and all levels and ages of colonial society was a part of the action undertaken by governors' wives in the carrying out of their duties. Such behaviour displayed their ability and willingness to mix and mingle while in New Zealand.

As well as decorating and entertaining to meet colonial society's expectations, governors' wives also put personal items on display at Government

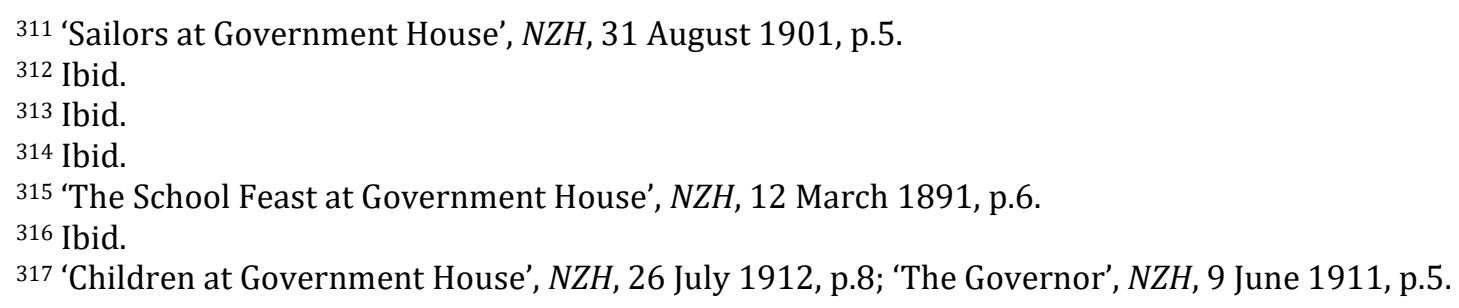


House. The Press, in its description of the 1898 Birthday Ball noted that Her Excellency had out on display a large 'kiwi mat' (possibly a korowai or cloak) hanging from the balustrade which was gifted to Lady Ranfurly by Major Kemp (Te Keepa Te Rangihiwinui, a prominent Māori leader) prior to his death. In Lady Ranfurly's own sitting room some of her paintings and photographs were also on display. ${ }^{318}$ Exhibiting items of personal importance around Government House was common. Lady Ranfurly generally chose to display her watercolours for viewing. At her first 'at home' she placed several of these on easels throughout the drawing rooms for the gaze of whomever wished to look. ${ }^{319}$ Likewise, Lady Plunket displayed personal items at Government House events she hosted. At one ball she made use of a large silver gilt candelabra given to her father many years before by friends in Paris. It had, apparently, once belonged to "one of the Napoleons". ${ }^{20}$ At another ball in 1907, the "fine stags' heads obtained by Lord Plunket last season" hung in the billiard room. ${ }^{321}$ Lady Islington, too, displayed personal items around Government House. At a reception in 1910, some "lovely old engravings" and two black and white drawings of Lady Islington by Sargent decorated the walls. ${ }^{322}$ On this occasion, the Evening Post seemed quite taken with the items on display, noting that " $[\mathrm{t}]$ here were so many interesting and charming things to look at: some pieces of tapestry, such as we never have an opportunity of seeing here, an autograph letter of Lord Nelson's, beautiful paintings, and a most fascinating French clock on each mantelpiece."323

By adding personal touches to the décor at Government House for public display, vice-regal wives provided guests - and those who read newspapers - an opportunity to glimpse something of their personal tastes and private lives, while in all likelihood also prompting conversation points for guests. The items on display also boasted of the family's accomplishments and hobbies, whether that be through exhibiting paintings or hunting trophies. Objects with a story behind them demonstrated the elite circles governors' wives moved in. Major Kemp's 'kiwi mat', the Napoleon candelabra, Sargent's drawings, and Nelson's letter all lent their prestige to the vice-regal residence. These objects, through their association with

\footnotetext{
318 'The Birthday Ball in Wellington', Press, 27 May 1898, p.5.

319 Iolanthe, 'Lady Correspondents', Press, 2 September 1897, p.2.

320 'Ball at Government House', ODT, 9 July 1904, p.8.

321 'Ball at Government House', Press, 5 September 1907, p.4.

322 'Reception at Government House', EP, 12 December 1910, p.9.

323 Ibid.
} 
notable figures, were vested with significance and novelty, which in turn lent itself to the governors and their wives. In particular the drawings of Lady Islington by John Singer Sargent, an American-born but Europe-based artist, who achieved international celebrity in the 1890 s for his portraits of the aristocratic, rich, and famous, would have demonstrated the elite status and wealth of the Islingtons to the New Zealand public. ${ }^{324}$ More than this though, displaying personal items provided a touch of the private in what was also a public home.

The dual reality of Government House was demonstrated in 1888 when thenGovernor Sir William Jervois undertook two separate trips to Australia. His first trip was in January, when he went to Sydney to participate in celebrations marking the centenary of the arrival of the 'first British fleet' to Port Jackson in New South Wales. ${ }^{325}$ In July and August he was in Melbourne to take part in the opening of the Melbourne Exhibition, at which New Zealand presented an exhibit.326 On both occasions that he was absent from New Zealand, Lady Jervois (who had remained in New Zealand), either removed herself from Government House, or else ceased to entertain. During the January trip, Lady Jervois left Government House Wellington to reside at the house and grounds of $\mathrm{A}$. H. Renwick at Johnsonville, north of Wellington city. The New Zealand Herald explained that she would remain there with her family until the Governor returned from Australia. ${ }^{327}$ Later that year while the Governor was in Melbourne, the New Zealand Herald's women's column explained that Lady Jervois would "not be at home after this Tuesday until further notice is given." 328 According to 'Dorothy', the author of the column, this announcement "caused a little astonishment" since, "[a]s a rule, during session time, there has been a regular weekly reception [at Government House]." ${ }^{229}$ Following the return of the Governor in late August, Lady Jervois reinstated her receptions on Tuesdays. 330

\footnotetext{
324 Trevor Fairbrother, John Singer Sargent (New York: Harry N. Abrams, Inc., 1994), chapter V. 325 'Australian Centenary', NZH, 27 January 1888, p.5; 'Our Letter Home', NZH, 27 February 1888, p.1 (supplement).

326 'The Melbourne Exhibition', Press, 9 August 1888, p.5; 'The Melbourne Exhibition and Gold Mining', EP, 19 July 1888, p.2; 'Summary for Europe', ODT, 8 August 1888, p.5, column 2.

327 'Wellington Items', NZH, 19 January 1888, p.5.

328 Dorothy, 'A Lady's Letter from Wellington', NZH, 21 July 1888, p.1 (supplement).

329 Ibid.

330 Dorothy, 'A Lady's Letter from Wellington', NZH, 25 August 1888, p.1 (supplement).
} 
Lady Jervois' actions suggest that she felt she had little right to remain in Government House or keep up her hosting duties on those occasions the Governor was absent from New Zealand. Certainly that was the view taken by 'Dorothy' in the New Zealand Herald. When Lady Jervois took up her receptions again in August 1888, 'Dorothy' thought that: "[p]ossibly one of the reasons why [she gave up her receptions] was because in reality Lady Jervois was not Governor's wife after His Excellency had left the colony, and so, therefore, did not see why she should hold her vice-regal receptions." ${ }^{331}$ Lady Jervois' actions seem mostly to have been accepted by the New Zealand public, although "a number of people made somewhat unfavourable comments upon Government House being closed during session time." 332 The issue for most was that the social season would be largely curtailed with Government House effectively closed for a month. Although this situation appears not to have arisen again, 333 this episode nevertheless accurately illustrated where vice-regal authority resided (in the governor), as well as illustrating the tension created by the public and private nature of Government House. Although it acted as the primary residence of the governor and his family while in New Zealand, it nonetheless remained a public building. At the same time as it served as a private family home it also served as a public space for New Zealand society to mix and meet and for the governor to carry out his official duties. How this double space was negotiated by governors' wives, is demonstrative of how they negotiated carrying out their vice-regal duties.

Through their dress and the display and use of Government House, governors' wives communicated their vice-regal identity to the New Zealand public. Having no official uniform, they instead dressed richly and expensively as a means of displaying their status and elite position to New Zealand society. They also took care to dress for the occasion, wearing their finest and most elaborate clothing and jewels to ceremonial or important events such as balls, and dressing in a more sombre fashion for the

331 Ibid.

332 Ibid.

333 Lady Jervois absenting herself from Government House was the only such episode uncovered during research for this thesis. While this does not mean that it did not happen again, it seems unlikely that it would have. As mentioned earlier, Lady Jervois' class background seems to have had some effect on how she undertook her vice-regal wifely duties compared with those wives that followed. Her actions on these two occasions could be due in part to this aspect of her background. 
opening of Parliament and other similarly important and serious events. Their rank and position were also communicated through reports in newspapers which described their dress ahead of others and in greater detail, with a few notable exceptions. Dress served to communicate the position, rank, wealth, and good taste of governors' wives to the colonial public.

Government House, too, provided a space for display and performance of status and the imperial position of governors' wives. They decorated lavishly for social engagements, putting on a spectacle of expense and good taste for those who attended events they hosted. Through the items on display - many of which were personal belongings - governors' wives also managed to communicate something of their private identity and family history. Actions such as these allowed governors' wives to insert something of the personal into what was otherwise a very public life and house. The same can be said of the entertainments provided by the wives on these occasions. Whether they themselves performed by singing or playing music, or whether they waited on their guests, they were engaged in communicating their private identity to those who were in attendance.

At the same time, governors' wives engaged in a performance of vice-regal office. By dressing for events - be they social, ceremonial or other - governors' wives established their position as elite figures of public interest in New Zealand. Their 'uniform' of elaborate and expensive dress, accessorised with fabulous jewellery, along with their comportment at public events, would have reinforced the position and place they held as governors' wives. Routinely participating in the ornamentation of vice-regal life across the years from 1887 to 1926 was a performative action, one that confirmed and communicated to the public that this woman was the wife of the monarch's representative. Through their dress and the decoration of Government House, governors' wives communicated their suitability for the position and for holding vice-regal office alongside their husbands. 


\section{Conclusion}

The principal aim of this thesis has been to study governors' wives in New Zealand between 1887 and 1926 with a particular focus on the public enactment of the viceregal wife's duties. In pursuit of this aim, this thesis has drawn on the calendar of public events and on the public narration of vice-regal duties as reported in contemporary newspaper reports. Discussion has focussed on three distinct areas of vice-regal life: the wife's position in vice-regal ceremony and social life; her involvement in voluntary welfare and women's imperialist organisations; and the display of office through the wife's dress and the decoration of Government House. Throughout, the thesis has been concerned with exploring what it meant to be a figure at the pinnacle of constitutional and social life, and at the same time a figure defined by marriage, in the late nineteenth and early twentieth centuries.

Throughout the years from 1887 to 1926, vice-regal ceremony followed a remarkable consistency and stability in its form and enactment. The rites and rituals of ceremonies such as the state opening of Parliament and the taking of the oaths of office by the governor remained virtually unchanged over this period. Within these traditions, the governor's wife occupied a space as a witness, observing and confirming the enactment of constitutional events, an action that was especially important in a country without a written constitution. Although she herself did not actively participate in the ceremonies, her presence nonetheless lent legitimacy to the governor in the carrying out of his duties. Her attendance reinforced the marital status of the governor, which itself imbued the governor with authority and probity.

Marriage was a crucial element in marking the governor out as a man fit for vice-regal office. In this sense, the position of governors' wives was indelibly tied to their identities as wives. Social engagements at which the governors and their wives attended or hosted also reinforced the wifely identity. Marriage was on display at balls, garden parties, and receptions when married couples opened the dancing, guests attended as husbands and wives, and the governor and his wife were present as a married pair. Vice-regal ceremony and social life was characterised by constancy and stability throughout this period, with governors' wives occupying a 
fixed space. Yet at the same time these years witnessed a greater recognition afforded to the part played by governors' wives in carrying out the duties of viceregal office, as indicated by the increasing use of the honorific 'Her Excellency' in reference to governors' wives. Although the position was not an official one, it nonetheless expanded in importance over this period even if the duties associated with the position changed but little.

Involvement in voluntary welfare and women's imperialist organisations was likewise an important aspect of the duties carried out by governors' wives throughout the late nineteenth and early twentieth centuries in fulfilment of viceregal office. From the 1880s onwards, governors' wives took on positions as patrons of various organisations, visited homes and orphanages, and attended fund raising events in fulfilment of their philanthropic duty. Their presence or participation in an organisation's work, particularly that concerning fund raising, could have a beneficial impact on the effectiveness and prosperity of that organisation. Lady Jervois' commitment to the work of the Girls' Friendly Society in the 1880s, Lady Plunket's energy and work for the Royal New Zealand Plunket Society in the 1900s, and Lady Liverpool's initiative and leadership in women's contribution to the war effort in World War One are examples of the impact that governors' wives had over this period in undertaking such works.

The work undertaken by governors' wives for voluntary organisations throughout the 1880s and 1920s was gendered in nature, in that it focussed on women carrying out work for the benefit of other women. The societies founded by or in which governors' wives were heavily involved were often concerned with women's welfare. The Girls' Friendly Society sought to provide aid and friendship to young women emigrating to New Zealand by helping them find respectable work and accommodation. The Plunket Society hoped to improve infant health by teaching women child raising techniques. The society had a distinctly new and modern focus on scientific methods of raising and looking after infants, but at the same time was largely conservative in that it considered women should be mothers rather than seeking out education or employment. Likewise the Mothers' Union, founded in 1893 and with which Lady Glasgow was heavily involved, shared a vision of women's duty to society as one in which women were responsible for raising 
children to be good members of the Empire. In addition, the Lady Liverpool Fund, while not concerned directly with women's welfare, nonetheless encouraged women to take up distinctly gendered patriotic work for the war effort. Governors' wives, through their involvement in organisations with such a particular focus, indicated their adherence to conservative notions of women's role in public life. That these organisations arose in an environment where New Zealand women had won the vote and continued to agitate for greater political rights for women, throws the wives' involvement in such societies into greater relief.

Vice-regal dress and decoration contributed also to the position occupied by governors' wives in New Zealand over the years from 1887 to 1926. Through their dress, governors' wives enacted their high status and wealth, and also displayed their femininity in contrast to their husband's ultra-masculine appearance in his vice-regal uniform. Their dress was also ultimately conservative, in that they did not set fashion trends or step outside the bounds of propriety in their clothing choices. Governors' wives tailored their dress to suit specific events and occasions, to display their identity as vice-regal wives, and uphold vice-regal office. The focus of newspaper reports on vice-regal dress and the placement of reports of dress and decoration further emphasised the position of governors' wives. Governors' wives always took precedence in reports on dress, the only exceptions being royal tours or if a foreign lady was the host of an event, as happened with Ladies Ranfurly and Fergusson.

In a similar fashion, the decoration and use of Government House was also constructed so as to emphasise and communicate the suitability of governors and their wives for vice-regal office. The richness and expense of the furnishings, the spectacle and ornamentation on display, and the entertainments offered at viceregal events all contributed to establishing the position of the governor and his wife as worthy representatives of the monarch. Personal items with a link to a famous name, such as Lady Plunket's 'Napoleon' candelabra or Lady Islington's drawing by Sargent, provided conversation points and also gave a sense of the private in what was otherwise a very public home. The tension between the public and private aspects of Government House was also indicated through the actions of Lady Jevois choosing to remove herself from the House while her husband was out of the 
country. In addition, this episode reinforced the unofficial position of governors' wives, and illustrated the fact that these women were in the position due to their marriage.

This study has also sought to consider how the public position of governors' wives can be understood through the framework of Judith Butler's concept of gender performativity. Returning briefly to Butler, one of the cornerstones of her idea of performativity is that gender identities are formed through repeated actions which themselves work to constitute that identity. These behaviours and actions are not performed consciously by a subject but rather work to create the subject. Looking then to governors' wives, this study has shown them to be consistently engaged in a performative enactment of their duties. By continuously fulfilling the same actions and behaviours when carrying out their vice-regal duties, governors' wives were acting performatively. Across the years from 1887 to 1926 they followed the same rituals in ceremonies and at social events, engaged with welfare and imperialist organisations that had a specific focus on women and children, and dressed and decorated in a manner that exemplified their position as elite women. There was little that changed across the final years of the nineteenth century and early decades of the twentieth century in how governors' wives carried out their duties, even as they were accorded more recognition in their position. Their position over these years represented a particular vision of women's public activity in an imperial world.

This vision was one in which women who were in a public position that gave them significant authority and power were circumscribed in their application of that power through their marriage and the nature of imperial public office. As women married to the monarch's representative, governors' wives were public figures with status and influence. But they remained defined by their marriage. Their position was an unofficial one, and all their power derived from their husbands as governors. As elite women in public life with authority and power, but as women fulfilling a defined imperial position, governors' wives occupied a space that allowed them a level of freedom. But that freedom was constrained by vice-regal office itself. That this tension in the space occupied by vice-regal wives existed at a time when debates 
about women's political rights and political activities were current, further indicates the complexity of governors' wives vice-regal identity.

By 1926, the end date for this thesis and the year the Balfour Declaration was signed, signalling the beginning of a shift in the imperial relationship between Britain and the Dominions, women had been able to vote in New Zealand elections for 34 years. From 1919 they could stand for election as candidates for Parliament, and although three women put forth their candidacy for that year's election, none were successful. ${ }^{334}$ The first woman elected to Parliament was the Labour Party's Elizabeth McCombs in 1933, but the total number of women Members of Parliament at any given time was slow to increase, only reaching 12 in 1984 (out of an 80-seat Parliament), and rising to 21 after the 1993 election. ${ }^{335}$ Even then, women members were slow to be accepted by the male-dominated House, and until recently had to negotiate a fine line between focussing on women-centric issues and broader political concerns. ${ }^{336}$ Women's involvement in public life in New Zealand was slow to develop over the twentieth century, and it was not until 1990 that a woman, Dame Catherine Tizard, was appointed to vice-regal office. ${ }^{337}$

The slow entry of women into positions of political authority in any great numbers sets the position held by New Zealand's governors' wives as women with substantial public authority into even greater relief, particularly between 1887 and 1926, and continuing on throughout the twentieth century. Governors' wives were symbols of the fact that marriage to a male figure of authority continued to be the main route to authority for a substantial portion of women in the twentieth century. Although the wives represented the possibility of a female presence in public life, the nature and duties of vice-regal office were in conflict with the enactment of that public authority. Governors' wives enacted their authority in ways that fit within the duties of vice-regal office. In addition, throughout the years from 1887 to 1926 and beyond, vice-regal office continued to be marked by a strong British presence as wealthy and socially elite British men continued to be appointed to office. The imperial link lasted until 1972 when Sir Denis Blundell, the first governor to be both

\footnotetext{
334 Martin, p.168.

335 Ibid, pp.229-230, 252-254, 298-299, 333.

336 Ibid, pp.252-254, 298-299.

337 McLean, p.324.
} 
born and resident in New Zealand, was appointed Governor-General. ${ }^{338}$ Not only were governors' wives representative of a particular vice-regal authority, they also represented the British social and governing elite.

As women married to men in public office, governors' wives occupied a particular space and position over the years from 1887 to 1926. Their position was one that afforded governors' wives status, authority, and power, but which was always defined by their marriage. Throughout the late nineteenth and early twentieth centuries, the position of governors' wives was one which displayed remarkable consistency in form, but which also underwent a shift as the part played by governors' wives in vice-regal office achieved greater public recognition. The governor's wife in New Zealand became a distinct figure in vice-regal office, one that was separate to the governor. The drive in this changing recognition came from both the public and governors' wives. The wives contributed to this shift in thinking through the continual performance of the duties of vice-regal office, while the public in turn witnessed these actions and came to understand the greater part played by governors' wives in vice-regal life and office. Governors' wives in New Zealand between 1887 and 1926 contributed to the enactment and richness of vice-regal life. All nine women from Lady Jervois in 1887 to Lady Fergusson in 1926 took up the position in New Zealand. For all except Lady Jervois it was a novel position, with specific duties and obligations, as well as providing particular benefits and rewards, and the way in which these nine women carried out the position helped to define and delineate it, and make it into a vice-regal position in its own right.

338 Ibid, p.291. 


\section{Bibliography}

\section{Primary Sources}

Newspapers and periodicals

Evening Post, 1887-1926

New Zealand Herald, 1887-1926

Otago Daily Times, 1887-1926

Press, 1887-1926

The Times (London), 1850-1968

\section{Official publications}

'Announcement of the Adoption of National Anthems for New Zealand', 21 November 1977, New Zealand Gazette, no. 117, 1977, p.3029.

\section{Unpublished Manuscripts}

Alice Fergusson - Letter to Mary Richmond, 77-173-3/6, Alexander Turnbull Library, Wellington.

Correspondence with Lord Jellicoe, 1921-1932, MS-Papers-5210-123, Alexander Turnbull Library, Wellington.

Correspondence with Lord Onslow, 1889-1890, MS-Papers-5210-095, Alexander Turnbull Library, Wellington.

Correspondence with Sir Charles and Lady Alice Fergusson, 1925-1926, MS-Papers5210-058, Alexander Turnbull Library, Wellington.

Friendly Work, 85-075-2/18, Alexander Turnbull Library, Wellington.

Friendly Work, 85-075-2/19, Alexander Turnbull Library, Wellington.

Islington family: Papers, 1912, 1924-1930, MS-Group-0848, Alexander Turnbull Library, Wellington.

Invitation to Her Majesty's Birthday Ball, 18 June 1895, MS-Papers-0267-12-002, Alexander Turnbull Library, Wellington.

Inward correspondence to the Earl and Countess of Ranfurly, 1897-1920, MSPapers-9364-1, Alexander Turnbull Library, Wellington.

Inward letters from Lord Glasgow, 1894-1897, MS-Papers-1619-003, Alexander Turnbull Library, Wellington. 
Inwards letters from Lord Onslow and Lord and Lady Plunket, 1893-1905, MSPapers-1619-008, Alexander Turnbull Library, Wellington.

Lady Islington - Illuminated address, MSZ-0867, Alexander Turnbull Library, Wellington.

[Lady Liverpool scrapbooks, 1912-1920], P f920 LIV SCR 1912-1920, Alexander Turnbull Library, Wellington.

Letter concerning refurbishment of Government House, MS-Papers-5755-73, Alexander Turnbull Library, Wellington.

Letters from Governors and Governor-Generals of New Zealand, 1893-1931, MSPapers-5210-101, Alexander Turnbull Library, Wellington.

Letters from Governors-General and aides, 1901-1954, MS-Papers-1619-146, Alexander Turnbull Library, Wellington.

Letters and memoranda from Lord Ranfurly, 1897-1899, MS-Papers-1619-004, Alexander Turnbull Library, Wellington.

Letters and memoranda from Lord Ranfurly, 1900, MS-Papers-1619-005, Alexander Turnbull Library, Wellington.

Letters and memoranda from Lord Ranfurly, 1901-1904, MS-Papers-1619-006, Alexander Turnbull Library, Wellington.

Personal Correspondence - Lord and Lady Ranfurly', 1901-1906, MS-Papers-1619007, Alexander Turnbull Library, Wellington.

\section{Secondary Sources}

\section{Books, Chapters, and Articles}

Alexander, Alison, “'Interfering Woman”: Jane Franklin and Van Diemen's Land Politics', Papers and Proceedings: Tasmanian Historical Research Association, Vol. 59, no. 2, August 2012, pp.77-94.

Alexander, Alison, The Ambitions of Jane Franklin (Sydney: Allen \& Unwin, 2013).

Altrincham, 'Poynder, John Poynder Dickson-, Baron Islington (1866-1936)', Oxford Dictionary of National Biography, updated January 2008; doi:10.1093/ref:odnb/35599; accessed 10 November 2014.

Auslander, Leora, 'Beyond Words', American Historical Review, Vol. 110, no. 4, 2005, pp.1015-1045.

Ballantyne, Tony and Antoinette Burton (eds.), Moving Subjects: Gender, Mobility, and Intimacy in an Age of Global Empire (Chicago: University of Illinois Press, 2009).

Bioletti, Harry, Whatever Happened to Lady Grey? A Look into the Private Lives of Lady Eliza Lucy Grey and Sir George Grey (Auckland: Harry Bioletti, 2001). 
Bradbury, Bettina, 'Colonial Comparisons: Rethinking Marriage, Civilization and Nations in the Nineteenth-century White Settler Societies', in Phillip Buckner and R. Douglas Francis (eds.), Rediscovering the British World (Calgary: University of Calgary Press, 2005), pp.135-157.

Bright, Judith, 'Girl Guides Association New Zealand 1908-', in Anne Else (ed.), Women Together: A History of Women's Organisations in New Zealand Ngā Rōpū Wāhine o te Motu (Wellington: Daphne Brasell Associates Press and Historical Branch, Department of Internal Affairs, 1993), pp.422-424.

Brookes, Barbara, Charlotte Macdonald and Margaret Tennant (eds.), Women in History 2 (Wellington: Bridget Williams Books, 1992).

Brown, Judith M. and Wm. Roger Louis (eds.), The Oxford History of the British Empire Volume IV: The Twentieth Century (Oxford: Oxford University Press, 1999)

Bryder, Linda, A Voice for Mothers: The Plunket Society and Infant Welfare, 19072000 (Auckland: Auckland University Press, 2003).

Bush, Barbara, 'Gender and Empire: The Twentieth Century' in Philippa Levine (ed.), Gender and Empire (Oxford: Oxford University Press, 2004), pp.77-111.

Bush, Julia, Edwardian Ladies and Imperial Power (London: Leicester University Press, 2000).

Butler, Judith, Gender Trouble: Feminism and the Subversion of Identity, (New York and London: Routledge, 2006).

Caine, Barbara, Victorian Feminists (Oxford: Oxford University Press, 1992).

Callaway, Helen and Dorothy 0. Helly, 'Crusader for Empire: Flora Shaw/Lady Lugard', in Nupur Chaudhuri and Margaret Strobel (eds.), Western Women and Imperialism: Complicity and Resistance (Bloomington and Indianapolis: Indiana University Press, 1992), pp.79-97.

Callaway, Helen, 'Dressing for Dinner in the Bush: Rituals of Self-Definition and British Imperial Authority', in Ruth Barnes and Joanne B. Eicher (eds.), Dress and Gender: Making and Meaning in Cultural Contexts (Oxford: Berg Publishers, 1992), pp.232-247.

Camiscioli, Elisa, 'Producing Citizens, Reproducing the "French Race": Immigration, Demography, and Pronatalism in Early Twentieth-Century France', Gender \& History, Vol. 13, no. 3, 2001, pp.593-621.

Cannadine, David, 'The Context, Performance and Meaning of Ritual: The British Monarchy and the "Invention of Tradition", c. 1820-1977', in Eric Hobsbawm and Terence Ranger (eds.), The Invention of Tradition (Cambridge: Cambridge University Press, 1983), pp.101-164.

Cannadine, David, 'Introduction: Divine Rites of Kings' in David Cannadine and Simon Price (eds.), Rituals of Royalty: Power and Ceremonial in Traditional Societies (Cambridge: Cambridge University Press, 1987). 
Cannadine, David, The Decline and Fall of the British Aristocracy (New Haven: Yale University Press, 1990).

Cannadine, David, Ornamentalism: How the British Saw Their Empire (Oxford: Oxford University Press, 2001).

Chapman, Lloyd, In a Strange Garden: The Life and Times of Truby King (Auckland: Penguin Books, 2003).

Conklin, Alice L., 'Redefining "Frenchness": Citizenship, Race Regeneration, and Imperial Motherhood in France and West Africa, 1914-40', in Julia ClancySmith and Frances Gouda (eds.), Domesticating the Empire: Race, Gender, and Family Life in French and Dutch Colonialism (Charlottesville and London: University Press of Virginia, 1998), pp.65-83, 286-293.

Coontz, Stephanie, Marriage, a History: From Obedience to Intimacy or How Love Conquered Marriage (New York: Viking Penguin, 2005).

Cooper, Nicholas, 'Rank, Manners and Display: The Gentlemanly House, 1500-1750', Transactions of the Royal Historical Society, Vol. 12, December 2002, pp.291310.

Crane, Diana, Fashion and Its Social Agendas: Class, Gender, and Identity in Clothing (Chicago: University of Chicago Press, 2000).

Davenport-Hines, Richard, 'Blackwood, Hariot Georgina Hamilton-Temple-, marchioness of Dufferin and Ava (1843-1936)', Oxford Dictionary of National Biography, updated January 2008; doi:10.1093/ref:odnb/56107; accessed 29 May 2015.

Davidoff, Leonore, The Best Circles: Society Etiquette and the Season (London: The Cresset Library, 1986).

Davidoff, Leonore and Catherine Hall, Family Fortunes: Men and Women of the English Middle Class, 1780-1850 (London: Hutchinson, 1987).

Downs, Laura Lee, Writing Gender History (New York: Hodder Arnold, 2004).

Fairbrother, Trevor, John Singer Sargent (New York: Harry N. Abrams, Inc., 1994).

Finlayson, Geoffrey, Citizen, State, and Social Welfare in Britain 1830-1990 (Oxford: Clarendon Press, 1994).

Foster, Bernard John, 'GLASGOW, David Boyle, Seventh Earl of', in A. H. McLintock (ed.), An Encyclopaedia of New Zealand, 1966, Te Ara - the Encyclopedia of New Zealand, updated 22 April 2009;

http://www.TeAra.govt.nz/en/1966/glasgow-david-boyle-seventh-earl-of; accessed 7 November 2014.

Foster, Bernard John, 'LIVERPOOL, Sir Arthur William de Brito Savile Foljambe, Earl of, P.C., G.C.B., G.C.M.G., G.B.E., M.V.O., K.J.St.J.', in A. H. McLintock (ed.), An Encyclopaedia of New Zealand, 1966, Te Ara - the Encyclopedia of New Zealand, updated 23 April 2009;

http://www.TeAra.govt.nz/en/1966/liverpool-sir-arthur-william-de-brito- 
savile-foljambe-earl-of-pc-gcb-gcmg-gbe-mvo-kjstj; accessed 10 November 2014.

Foster, Bernard John, 'PLUNKET, Sir William Lee Plunket, Fifth Baron, G.C.V.O., G.C.M.G., K.B.E., K.G.ST.J., B.A.', in A. H. McLintock (ed.), An Encyclopaedia of New Zealand, 1966, Te Ara - the Encyclopedia of New Zealand, updated 22 April 2009; http://www.teara.govt.nz/en/1966/plunket-sir-william-leeplunket-fifth-baron-gcvo-gcmg-kbe-kgstj-ba; accessed 10 November 2014.

Foster, Bernard John, 'RANFURLY, Sir Uchter John Mark Knox, Fifth Earl of, P.C., G.C.M.G., Bailiff Grand Cross of the Order of St. John, Deputy Lieutenant and Justice of the Peace, County Tyrone', in A. H. McLintock (ed.), An Encyclopaedia of New Zealand, 1966, Te Ara - the Encyclopedia of New Zealand, updated 23 April 2009; http://www.TeAra.govt.nz/en/1966/ranfurly-sir-uchter-john-mark-knoxfifth-earl-of-pc-gcmg-bailiff-grand-cross-of-the-order-of-st; accessed 10 November 2014.

Francis, Mark, Governors and Settlers: Images of Authority in the British Colonies, 1820-60 (London: Macmillan Academic and Professional Ltd, 1992).

Gambrill, Mollie D., Girls' Friendly Society in New Zealand 1882-1983 [Wellington: Girls' Friendly Society, 1983].

Gernsheim, Alison, Fashion and Reality (London: Faber and Faber, 1963).

Gillis, John R., For Better, For Worse: British Marriages, 1600 to the Present (New York, Oxford: Oxford University Press, 1985).

Goffman, Erving, The Presentation of Self in Everyday Life (New York: Doubleday Anchor Books, 1959).

Goodman, Dena and Kathryn Norberg, 'Introduction', in Dena Goodman and Kathryn Norberg (eds.), Furnishing the Eighteenth Century: What Furniture Can Tell Us about the European and American Past (New York: Routledge, 2007).

Griffith, J. A. G. and Michael Ryle, Parliament: Functions, Practice and Procedures (London: Sweet \& Maxwell, 1989).

Haggis, Jane, ‘Gendering Colonialism or Colonising Gender? Recent Women's Studies Approaches to White Women and the History of British Colonialism', Women's Studies International Forum, Vol. 13, nos. 1-2, 1990, pp.105-115.

Hall, Catherine, 'Of Gender and Empire: Reflections on the Nineteenth Century' in Philippa Levine (ed.), Gender and Empire (Oxford: Oxford University Press, 2004), pp.46-76.

Hay, Elizabeth, 'Association of Anglican Women 1886-', in Anne Else (ed.), Women Together: A History of Women's Organisations in New Zealand Ngā Rōpū Wāhine o te Motu (Wellington: Daphne Brasell Associates Press and Historical Branch, Department of Internal Affairs, 1993), pp.165-167.

Hobsbawm, Eric and Terence Ranger (eds.), The Invention of Tradition (Cambridge: Cambridge University Press, 1995). 
Honeyman, Katrina, 'Following Suit: Men, Masculinity and Gendered Practices in the Clothing Trade in Leeds, England, 1890-1940', Gender \& History, Vol. 14, no. 3, November 2002, pp.426-446.

Hunter, Kate and Kirstie Ross, Holding on to Home: New Zealand Stories and Objects of the First World War (Wellington: Te Papa Press, 2014).

Jalland, Pat, Women, Marriage and Politics 1860-1914 (Oxford: Oxford University Press, 1986).

Jayawardena, Kumari, The White Woman's Other Burden: Western Women and South Asia During British Colonial Rule (London: Routledge, 1995).

Jones, Christopher, The Great Palace: The Story of Parliament (London: British Broadcasting Corporation, 1983).

Kinross, John S., 'Jervois, Sir William Francis Drummond (1821-1897)', Oxford Dictionary of National Biography, updated May 2009; doi:10.1093/ref:odnb/14800; accessed 7 November 2014.

Laidlaw, Zoë, Colonial Connections, 1815-45: Patronage, the Information Revolution and Colonial Government (Manchester and New York: Manchester University Press, 2005).

Lambert, Andrew, 'Jellicoe, John Rushworth, first Earl Jellicoe (1859-1935)', Oxford Dictionary of National Biography, updated May 2013; doi:10.1093/ref:odnb/34171 ; accessed 11 November 2014.

Levine, Philippa, 'Introduction: Why Gender and Empire?' in Philippa Levine (ed.), Gender and Empire (Oxford: Oxford University Press, 2004), pp.1-13.

Loveridge, Steven, Calls to Arms: New Zealand Society and Commitment to the Great War (Wellington: Victoria University Press, 2014).

Macdonald, Charlotte, The Vote, the Pill and the Demon Drink: A History of Feminist Writing in New Zealand 1869-1993 (Wellington: Bridget Williams Books, 1993).

Mansel, Philip, Dressed to Rule: Royal and Court Costume from Louis XIV to Elizabeth II (London: Yale University Press, 2005).

Martin, John E., The House: New Zealand's House of Representatives 1854-2004 (Palmerston North: Dunmore Press, 2004).

McCallum, Janet, Women and their Words: Notable Pioneers in New Zealand Journalism (Masterton, New Zealand: Fraser Books, 2009).

McGibbon, Ian, 'Jellicoe, John Henry Rushworth', Dictionary of New Zealand Biography, Te Ara - the Encyclopedia of New Zealand, updated 23 October 2013; http://www.TeAra.govt.nz/en/biographies/4j4/jellicoe-john-henryrushworth; accessed 11 November 2014.

McGibbon, Ian, 'Jervois, William Francis Drummond', Dictionary of New Zealand Biography, Te Ara - the Encyclopedia of New Zealand, updated 30 October 2012; http://www.TeAra.govt.nz/en/biographies/2j2/jervois-williamfrancis-drummond; accessed 7 November 2012. 
McIntyre, W. David, The Commonwealth of Nations: Origins and Impact, 1869-1971

(Minneapolis: University of Minnesota Press, 1977).

McIntyre, W. David, Dominion of New Zealand: Statesmen and Status 1907-1945

(Wellington: New Zealand Institute of International Affairs, 2007).

McKergow, Fiona, 'Girls' Friendly Society 1882 -', in Anne Else (ed.), Women Together: A History of Women's Organisations in New Zealand Ngā Rōpū Wāhine o te Motu (Wellington: Daphne Brasell Associates Press and Historical Branch, Department of Internal Affairs, 1993), pp.129-131.

McLean, Gavin, The Governors: New Zealand's Governors and Governors-General (Dunedin: Otago University Press, 2006).

McLeish, Val, 'Sunshine and Sorrows: Canada, Ireland and Lady Aberdeen', in David Lambert and Alan Lester (eds.), Colonial Lives Across the British Empire: Imperial Careering in the Long Nineteenth Century (New York: Cambridge University Press, 2006), pp.257-284.

Mein Smith, Philippa, Peter Hempenstall and Shaun Goldfinch with Stuart McMillan and Rosemary Baird, Remaking the Tasman World (Christchurch: Canterbury University Press, 2008).

Mendes, Valerie and Amy de la Haye, 20 $0^{\text {th }}$ Century Fashion (London: Thames \& Hudson, 1999).

Midgley, Clare (ed.) Gender and imperialism (Manchester: Manchester University Press, 1998).

Midgley, Clare, Feminism and Empire: Women Activists in Imperial Britain, 1790-1865 (New York: Routledge, 2007).

Morris, Grant, Prendergast: Legal Villain? (Wellington: Victoria University Press, 2014).

Myers, Janet C., 'Performing the Voyage Out: Victorian Female Emigration and the Class Dynamics of Displacement', Victorian Literature and Culture, Vol. 29 no. 1, 2001, pp.129-146.

Olssen, Erik, 'Truby King and the Plunket Society: An Analysis of a Prescriptive Ideology', New Zealand Journal of History, Vol. 15, no. 1, 1981, pp.3-23.

Oppenheimer, Melanie, "Hidden under many bushels" Lady Victoria Plunket and the New Zealand Society for the Health of Women and Children', New Zealand Journal of History, Vol. 39, no. 1, 2005, pp.22-38.

Oppenheimer, Melanie, “The “imperial” girl: Lady Helen Munro Ferguson, the imperial woman and her imperial childhood', Journal of Australian Studies, Vol. 34, no. 4, December 2010, pp.513-525.

Parry, Gordon, A Fence at the Top: The First 75 Years of the Plunket Society ([Dunedin]: Royal new Zealand Plunket Society, 1982).

Pickles, Katie, 'A link in "the great chain of Empire friendship": the Victoria League in New Zealand', The Journal of Imperial and Commonwealth History, Vol. 33, no. 1, January 2005, pp.29-50. 
Pickles, Katie, Female Imperialism and National Identity: Imperial Order Daughters of the Empire (Manchester: Manchester University Press, 2002).

Porter, Andrew (ed.), The Oxford History of the British Empire Volume III: The Nineteenth Century (Oxford: Oxford University Press, 1999).

Porter, Frances and Charlotte Macdonald (eds.), 'My Hand Will Write What My Heart Dictates'. The unsettled lives of women in nineteenth-century New Zealand as revealed to sisters, family and friends (Auckland: Bridget Williams Books and Auckland University Press, 1996).

Prochaska, Frank, Royal Bounty: The Making of a Welfare Monarchy (New Haven \& London: Yale University Press, 1995).

Prochaska, F. K., Women and Philanthropy in Nineteenth-Century England (New York: Oxford University Press, 1980).

Procida, Mary A., Married to the empire: Gender, Politics and Imperialism in India, 1883-1947 (Manchester: Manchester University Press, 2002).

Rei, Tania, 'Lady Liverpool's and Mrs Pōmare's Māori Soldiers' Fund, 1915-1921', in Anne Else (ed.), Women Together: A History of Women's Organisations in New Zealand Ngā Rōpū Wāhine o te Motu (Wellington: Daphne Brasell Associates Press and Historical Branch, Department of Internal Affairs, 1993), pp.23-24.

Rubinstein, W. D., 'Onslow, William Hillier, fourth earl of Onslow (18531911)', Oxford Dictionary of National Biography, updated October 2007; doi:10.1093/ref:odnb/35317; accessed 7 November 2014.

Russell, Penny, 'The Brash Colonial: Class and Comportment in Nineteenth-Century Australia', Transactions of the Royal Historical Society, Vol. 12, December 2002, pp.431-453.

Russell, Penny, 'Introduction', in Penny Russell (ed.), For Richer, for Poorer: Early Colonial Marriages (Melbourne: Melbourne University Press, 2004), pp.1-11.

Russell, Penny, 'Wife Stories: Narrating Marriage and Self in the Life of Jane Franklin', Victorian Studies, Vol. 48, no. 1, Autumn 2005, pp.35-57.

Russell, Penny, 'A Woman of the Future? Feminism and Conservatism in Colonial New South Wales', Women's History Review, Vol. 13, no. 1, 2004, pp.69-90.

Salesa, Damon Ieremia, Racial Crossings: Race, Intermarriage, and the Victorian British Empire (Oxford: Oxford University Press, 2011).

Seeley, John Robert, The Expansion of England: Two Courses of Lectures (London: Macmillan and Co., 1883).

Selzer, Anita, Governors' Wives in Colonial Australia (Canberra: National Library of Australia, 2002).

Sinclair, Keith, A History of New Zealand, rev. ed. (Auckland: Penguin Books, 2000).

Sinclair, Keith, 'Reeves, William Pember', Dictionary of New Zealand Biography, Te Ara - the Encyclopedia of New Zealand, updated 14 January 2014; 
http://www.teara.govt.nz/en/biographies/2r11/reeves-william-pember; accessed 28 May 2015.

Sparke, Penny, As Long As It's Pink: The Sexual Politics of Taste (London: Pandora, 1995).

Stoler, Ann Laura, Carnal Knowledge and Imperial Power: Race and the Intimate in Colonial Rule (Berkeley: University of California Press, 2002).

Stoler, Ann Laura, 'Making Empire Respectable: The Politics of Race and Sexual Morality in $20^{\text {th }}$-Century Colonial Cultures', American Ethnologist, Vol. 16, no. 4, 1989, pp.634-660.

Taylor, Elizabeth, The Old World and the New: The Marriage and Colonial Adventures of Lord and Lady Northcote (Newcastle upon Tyne: Cambridge Scholars Publishing, 2013).

Tennant, Margaret, The Fabric of Welfare: Voluntary Organisations, Government and Welfare in New Zealand, 1840-2005 (Wellington: Bridget Williams Books, 2007).

Thomas, Nicola J., 'Mary Curzon: “American Queen of India”', in David Lambert and Alan Lester (eds.), Colonial Lives Across the British Empire: Imperial Careering in the Long Nineteenth Century (New York: Cambridge University Press, 2006), pp.285-308.

Thompson, Andrew, The Empire Strikes Back? The Impact of Imperialism on Britain from the Mid-Nineteenth Century (Harlow, England: Pearson Education Limited, 2003).

Thompson, Dorothy, Queen Victoria Gender and Power (London: Virago Press, 1990).

Thomson, David, A World Without Welfare: New Zealand's Colonial Experiment (Auckland: Auckland University Press with Bridget Williams Books, 1998).

Tosh, John, 'Gentlemanly Politeness and Manly Simplicity in Victorian England', Transactions of the Royal Historical Society, Vol. 12, December 2002, pp.455472.

Wanhalla, Angela, Matters of the Heart: A History of Interracial Marriage in New Zealand (Auckland: Auckland University Press, 2013).

Wilson, Elizabeth, Adorned in Dreams; Fashion and Modernity, rev. ed. (London: I. B. Tauris \& Co., 2003).

Wheeler-Bennett, John, 'Fergusson, Sir Charles, of Kilkerran, seventh baronet (18651951)', rev. Roger T. Stearn, Oxford Dictionary of National Biography, updated 2004; doi:10.1093/ref:odnb/33111; accessed 11 Nov 2014.

Woods, Joanna, Diplomatic Ladies: New Zealand's Unsung Envoys (Dunedin: Otago University Press, 2012).

Woollacott, Angela, Gender and empire (New York: Palgrave Macmillan, 2006). 


\section{Unpublished Theses and Research Essays}

Andrews, Amanda, 'The Great Ornamentals: New Vice-Regal Women and their Imperial Work 1884-1914', PhD thesis, University of Western Sydney, 2004.

Le Dorré, Lillie, 'Dancing Debs: Debutante Balls in Twentieth Century New Zealand, c.1920-1975', BA (Hons) research essay in History, Victoria University of Wellington, 2012.

Reeves, Beverley, 'The effect on a woman's life of being married to a man of high status', MA thesis, Victoria University of Wellington, 2000.

Tennant, Margaret, 'Matrons with a Mission: Women's Organisations in New Zealand 1893-1915', MA Thesis, Massey University, 1976.

\section{Websites}

'Government House Auckland', http://gg.govt.nz/government-house/other; accessed 12 May 2015.

'House and Grounds', https://gg.govt.nz/government-house/house-and-grounds; accessed 12 May 2015.

'Other Government Houses', http://gg.govt.nz/content/other-government-houses; accessed 12 May 2015.

'Vice-Regal Patronage', http://gg.govt.nz/the-governor-general/patronage; accessed 3 February 2015. 